\title{
Effects of natural and human-induced hypoxia on coastal benthos
}

\author{
L. A. Levin ${ }^{1}$, W. Ekau ${ }^{2}$, A. J. Gooday ${ }^{3}$, F. Jorissen ${ }^{4}$, J. J. Middelburg ${ }^{5}$, S. W. A. Naqvi' ${ }^{6}$, C. Neira ${ }^{1}$, N. N. Rabalais ${ }^{7}$, \\ and J. Zhang ${ }^{8}$ \\ ${ }^{1}$ Integrative Oceanography Division, Scripps Institution of Oceanography, 9500 Gilman Drive, La Jolla, \\ CA 92093-0218, USA \\ ${ }^{2}$ Fisheries Biology, Leibniz Zentrum für Marine Tropenökologie, Leibniz Center for Tropical Marine Ecology, Fahrenheitstr. \\ 6, 28359 Bremen, Germany \\ ${ }^{3}$ National Oceanography Centre, Southampton, European Way, Southampton SO14 3ZH, UK \\ ${ }^{4}$ Laboratory of Recent and Fossil Bio-Indicators (BIAF), Angers University, 2 Boulevard Lavoisier, \\ 49045 Angers Cedex 01, France \\ ${ }^{5}$ Faculty of Geosciences, Utrecht University, P.O. Box 80021, 3508 TA Utrecht, The Netherlands \\ ${ }^{6}$ National Institution of Oceanography, Dona Paula, Goa 403004, India \\ ${ }^{7}$ Louisiana Universities Marine Consortium, Chauvin, Louisiana 70344, USA \\ ${ }^{8}$ State Key Laboratory of Estuarine and Coastal Research, East China Normal University, 3663 Zhongshan Road North, \\ Shanghai 200062, China
}

Received: 17 January 2009 - Published in Biogeosciences Discuss.: 3 April 2009

Revised: 21 August 2009 - Accepted: 21 August 2009 - Published: 8 October 2009

\begin{abstract}
Coastal hypoxia (defined here as $<1.42 \mathrm{ml} \mathrm{L}^{-1}$; $62.5 \mu \mathrm{M} ; 2 \mathrm{mg} \mathrm{L}^{-1}$, approx. $30 \%$ oxygen saturation) develops seasonally in many estuaries, fjords, and along open coasts as a result of natural upwelling or from anthropogenic eutrophication induced by riverine nutrient inputs. Permanent hypoxia occurs naturally in some isolated seas and marine basins as well as in open slope oxygen minimum zones. Responses of benthos to hypoxia depend on the duration, predictability, and intensity of oxygen depletion and on whether $\mathrm{H}_{2} \mathrm{~S}$ is formed. Under suboxic conditions, large mats of filamentous sulfide oxidizing bacteria cover the seabed and consume sulfide. They are hypothesized to provide a detoxified microhabitat for eukaryotic benthic communities. Calcareous foraminiferans and nematodes are particularly tolerant of low oxygen concentrations and may attain high densities and dominance, often in association with microbial mats. When oxygen is sufficient to support metazoans, small, soft-bodied invertebrates (typically annelids), often with short generation times and elaborate branchial structures, predominate. Large taxa are more sensitive than small taxa to hypoxia. Crustaceans and echinoderms are typically more sensitive to hypoxia, with lower oxygen thresholds, than annelids, sipunculans, molluscs and cnidarians.
\end{abstract}

Correspondence to: L. A. Levin (llevin@ucsd.edu)
Mobile fish and shellfish will migrate away from low-oxygen areas. Within a species, early life stages may be more subject to oxygen stress than older life stages.

Hypoxia alters both the structure and function of benthic communities, but effects may differ with regional hypoxia history. Human-caused hypoxia is generally linked to eutrophication, and occurs adjacent to watersheds with large populations or agricultural activities. Many occurrences are seasonal, within estuaries, fjords or enclosed seas of the North Atlantic and the NW Pacific Oceans. Benthic faunal responses, elicited at oxygen levels below $2 \mathrm{ml} \mathrm{L}^{-1}$, typically involve avoidance or mortality of large species and elevated abundances of enrichment opportunists, sometimes prior to population crashes. Areas of low oxygen persist seasonally or continuously beneath upwelling regions, associated with the upper parts of oxygen minimum zones (SE Pacific, W Africa, N Indian Ocean). These have a distribution largely distinct from eutrophic areas and support a resident fauna that is adapted to survive and reproduce at oxygen concentrations $<0.5 \mathrm{ml} \mathrm{L}^{-1}$. Under both natural and eutrophicationcaused hypoxia there is loss of diversity, through attrition of intolerant species and elevated dominance, as well as reductions in body size. These shifts in species composition and diversity yield altered trophic structure, energy flow pathways, and corresponding ecosystem services such as production, organic matter cycling and organic $\mathrm{C}$ burial. Increasingly the influences of nature and humans interact to generate

Published by Copernicus Publications on behalf of the European Geosciences Union. 


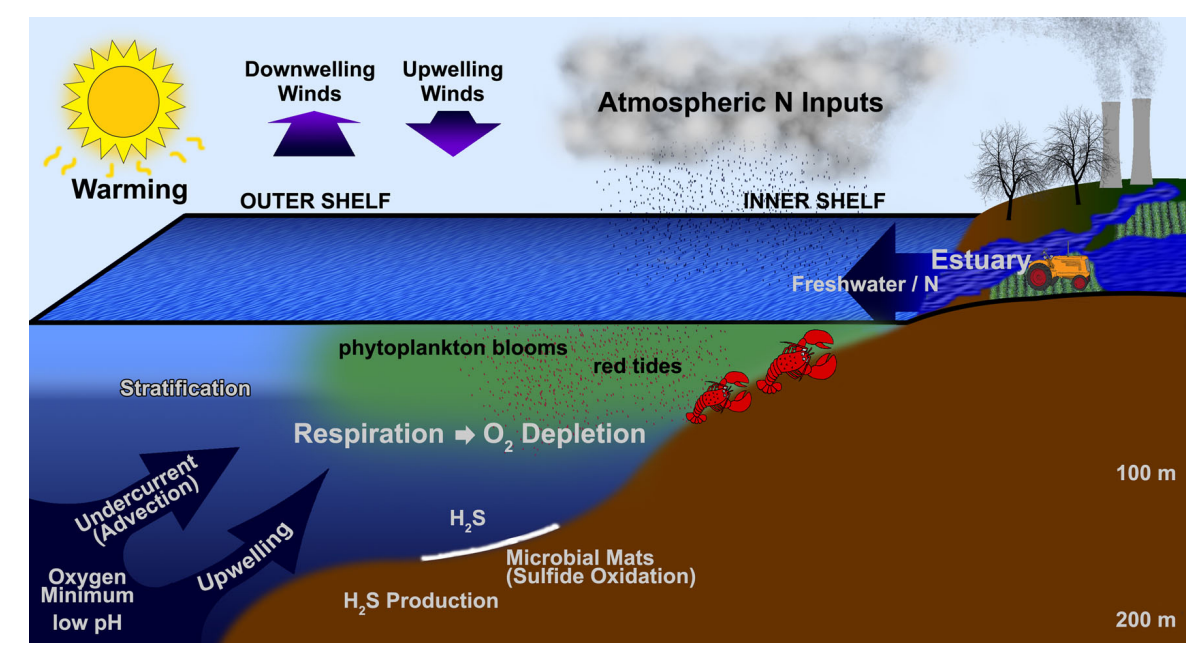

Fig. 1. Schematic diagram illustrating the mechanisms underlying the formation of hypoxia experienced by benthos along continental shelves.

or exacerbate hypoxia. A warmer ocean is more stratified, holds less oxygen, and may experience greater advection of oxygen-poor source waters, making new regions subject to hypoxia. Future understanding of benthic responses to hypoxia must be established in the context of global climate change and other human influences such as overfishing, pollution, disease, habitat loss, and species invasions.

\section{Introduction}

\subsection{Sources of coastal hypoxia}

Hypoxia, a shortage of dissolved oxygen, can originate in the ocean naturally, from human influences, or increasingly, from interactions between human activities and natural processes that make estuarine and coastal waters more susceptible to oxygen depletion. Fundamentally, the same processes are at work in most instances of natural and humaninduced hypoxia. Biological oxygen demand exceeds the supply of oxygen from surface waters, typically as a result of increased microbial respiration, stimulated by accumulated carbon from enhanced primary production in surface waters. The enhanced production results from increased nitrogen (and sometimes phosphorus) availability. Nutrients are injected into surface waters either as a result of upwelling (a natural process driven by winds that occurs along continental margins) or via air and rivers as a result of anthropogenic activities. Cultural eutrophication (sensu Nixon, 1995; Diaz and Rosenberg, 1995, 2001, 2008) typically occurs where human population or agricultural production is high (Rabalais, 2004). Nutrient enhancement stimulates excessive phytoplankton growth. When the resulting organic matter exceeds the capacity of metazoan consumers to metabolize it, the remaining organic matter settles to a pycnocline or the sediments, where it is decomposed, mainly by heterotrophic bacteria. This decay depletes the dissolved oxygen at a rate faster than resupply from surface, well-oxygenated waters because of the inhibited diffusion of dissolved oxygen across a sharp density difference, i.e. pycnocline.

Oxygen depletion is exacerbated in situations where water masses are highly stratified or isolated from oxygenated water bodies. Stratification results from strong thermal or salinity gradients including freshwater lenses formed from excessive rain or runoff from land. In many instances, warming or intense rainfall (e.g. monsoons) are seasonal events, and act to create seasonal hypoxia. Most of the time stratification is a natural process, but long-term warming trends in the ocean, climate-related precipitation changes, and altered riverine input can insert a human element (Fig. 1). Land-enclosed water bodies, such as estuaries, the Black or Baltic seas, fjords, silled basins and even the Arabian Sea, have a long residence time and little exchange with sources of oxygenated water. In regions and at water depths where well-oxygenated currents prevail, hypoxia is rapidly dissipated. The interaction of such currents (e.g. the California Current, the Humboldt Current, the Benguela Current) with strong upwelling and high primary production creates sharp natural oxygen gradients along the coast and continental margin.

Additional factors contributing to the development of natural hypoxia include the age, temperature and salinity of the water mass. Much of the ocean's new water is formed at high latitudes in the North Atlantic and Southern Ocean, and is supersaturated with oxygen due low surface temperatures that facilitate greater dissolution of oxygen. This oxygenrich water sinks and begins a long "conveyor-belt" like trek through the interior of the oceans (Rahmstorf, 2006). Oxygen is slowly used up over periods of over 1000-2000 years, 
leading to much lower base oxygen levels in the northern Pacific and Indian Oceans, than in the Atlantic and Southern Oceans. Hypersaline waters and warm waters hold less dissolved oxygen than cold, fresher water. Where warm, saline waters (e.g. from the Red Sea) enter the ocean (e.g. the Arabian Sea) or where waters are very old, hypoxia is more likely.

Finally, many continental shelf systems experience variable advection (or bathing) of low-oxygen waters from adjacent or deeper water masses or systems. Seasonal wind reversals can shift the relative influence of undercurrents that transport such waters, leading to seasonal hypoxia or even anoxia. Remote forcing of these currents, combined with warming and reduced wind stress (that normally drives ventilation), appear to dominate oxygen dynamics on the shelves of the central Benguela ecosystem off Namibia (Monteiro et al., 2008) and Oregon (Grantham et al., 2004), and off India (Naqvi et al., 2006). Larger-scale climate modes associated with Kelvin waves such as El Niño Southern Oscillations (ENSO Schaffer et al., 2002) and the Benguela Niño (Monteiro et al., 2008) force decadal shifts in shelf oxygenation by altering relative advection of equatorial water masses, although the oxygenation effects can be in opposite directions.

The factors described above (Fig. 1) can come together in different ways, over a range of space and time scales, to generate oxygen depletion of varying intensity, duration and recurrence. Within a single region, hypoxia severity can vary over time as a function of amount of productivity and degree of stratification (Rabalais and Turner, 2001; Naqvi et al., 2006; Rabalais et al., 2007b). How hypoxia affects benthos, and whether the effects vary fundamentally under conditions of human-caused versus natural hypoxia, will be the focus of this paper. Our goals are to (a) briefly review the time scales and sources of natural and human-induced hypoxia experienced by coastal benthic communities, (b) present case studies that illustrate benthic responses to hypoxia in estuarine, enclosed sea, inner shelf and outer shelf/slope environments, (c) provide a synthetic overview of oxygen thresholds and gradients responsible for population, community and ecosystem-level responses to hypoxia, distinguishing human and natural forcing where possible and (d) evaluate recovery potential, the influence of concurrent stresses, and future prospects for benthos subject to hypoxia. We treat all major benthic life forms, with the exception of microbial responses other than those of macroscopic, mat-forming sulfur bacteria.

\subsection{Coastal hypoxia: environments and time scales}

Coastal hypoxia will be treated here in three settings: estuaries and embayments, enclosed seas, and open continental shelves. Often there is a distinction between processes controlling hypoxia on the inner shelf $(\sim 0-100 \mathrm{~m})$, and those on the outer shelf/ upper slope $(100-400 \mathrm{~m})$. Where appropriate we have tried to emphasize this distinction (Fig. 1). In areas with deep shelves or steep continental margins, even depths below $200 \mathrm{~m}$ can be considered coastal. Open ocean, deep-water oxygen minimum zones (OMZs, $<0.5 \mathrm{ml} \mathrm{L}^{-1}$ ) occur permanently at depths between 100 and $1200 \mathrm{~m}$ in the Arabian Sea, the Bay of Bengal, the E South Pacific and E Subtropical North Pacific, and seasonally in the Gulf of Alaska and W Bering Sea. The world's OMZs have a surface area of 30.4 million $\mathrm{km}^{2}$ ( $8 \%$ of ocean area) (Paulmier and Ruiz-Pino, 2008), and where they intercept the slopes, confer hypoxia on about $2 \%$ or 1.15 million $\mathrm{km}^{2}$ of the continental margin (Helly and Levin, 2004). These settings and deep, silled basins subject to permanent hypoxia, though significant in area, will not be considered directly except where they impinge on the shelf or provide relevant ecological or evolutionary insight.

Different settings experience hypoxia on different time and space scales. Estuaries for example, are often subject to seasonal (on an annual basis) or episodic hypoxia (Diaz and Rosenberg, 1995, 2001). Sometimes hypoxia is localized within a specific tributary or in the shallow reaches of an estuary and affects only selected components of the benthic community. In shallow, well-mixed settings subject to nutrient loading, hypoxia may occur over diel cycles, with supersaturation resulting from primary production in daylight hours and anoxia resulting from heterotrophic respiration at night (Verity et al., 2006; Tyler et al., 2009). In contrast, enclosed seas are more likely to experience either permanent or long-term hypoxia over larger spatial scales. The Black, Baltic, and Azov seas encompass massive hypoxic regions. When the hypoxia is the result of eutrophication, as on the Black Sea shelf, active reductions in nutrient inputs can reverse low dissolved oxygen trends and reduce or eliminate hypoxia (Mee et al., 2005). Continental shelves receiving input from large rivers (e.g. Mississippi, Po, Rhine), or near large population centers, are bathed in nutrients from land, wastewater, or from atmospheric deposition. These coastal areas are likely to experience hypoxia during summer when high temperatures strengthen salinity stratification. In the Gulf of Mexico, this affects up to $22000 \mathrm{~km}^{2}$ each summer, in waters mainly shallower than $45 \mathrm{~m}$ (Rabalais and Turner, 2001; Rabalais et al., 2007b). Outer shelves are subject to the influence of interannual and decadal climate cycles as well as seasonal winds, through their effects on upwelling, downwelling and advection. On the Pakistan and West India margins there is a monsoon-driven seasonal shoaling of the oxygen minimum zone and additional development of inshore hypoxia (Naqvi et al., 2000, 2006; Brand and Griffiths, 2008). Similar conditions have developed in recent years on the Oregon inner shelf, although for different reasons (Grantham et al., 2004; Chan et al., 2008). On the Chile margin the inner shelves are seasonally hypoxic with low dissolved oxygen in austral summer (Sellanes et al., 2003). Outer shelves off Peru and Chile are subject to the pervasive influence of ENSO cycles. During normal and La Niña years production is high there and the regions below $100 \mathrm{~m}$ 
are permanently hypoxic. During El Niño events, strengthened influence from equatorial water masses oxygenates the shelf and deepens the upper boundary of the OMZ off Peru (Helly and Levin, 2004), whereas El Niño causes a shoaling of the OMZ and oxygen depletion on the southern California shelf (McClatchie et al., 2009).

\subsection{Oxygen thresholds and levels deleterious to benthos}

Dissolved oxygen (DO) concentrations are typically measured in units of $\mathrm{mg} \mathrm{L}^{-1}, \mathrm{mlL}^{-1}$, micromolar $\left(\mu \mathrm{M}=\mu \mathrm{mol} \mathrm{L}^{-1}\right)$ or percent saturation. From here on we will either present oxygen concentrations as $\mathrm{ml} \mathrm{L}^{-1}$, or present parallel conversion to these units when data are originally given in other units. Shelf hypoxia is often defined as oxygen levels of $<2 \mathrm{mg} \mathrm{L}^{-1}, 1.42 \mathrm{ml} \mathrm{L}^{-1}$, or $62.5 \mu \mathrm{M}$; in contrast, much lower concentrations of $0.5 \mathrm{ml} \mathrm{L}^{-1}$ are used to identify permanent oxygen minimum zones (Helly and Levin, 2004; Paulmier and Ruiz-Pino, 2008). However, at $2 \mathrm{mg} \mathrm{L}^{-1}$, DO shortages can induce avoidance, or altered behavior, growth, reproduction or survivorship in taxa for which normoxia is the rule. Hypoxia represents the degradation of water quality for an average species. Among fishes and invertebrates, different taxonomic groups, body sizes and skeletal types have different oxygen tolerances and thresholds (Diaz and Rosenberg, 1995; Wannamaker and Rice, 2000; Rabalais et al., 2001a; Karlson et al., 2002; Vaquer-Sunyer and Duarte, 2008), so that no single definition of hypoxia fits all organisms.

Mobile nekton on the northern Gulf of Mexico continental shelf will avoid oxygen levels $<2 \mathrm{mg} \mathrm{L}^{-1}\left(1.4 \mathrm{ml} \mathrm{L}^{-1}\right)$ (Pavela et al., 1983; Renaud, 1986). Fish avoidance generally occurs at oxygen concentrations 0.5 to $2 \mathrm{mg} \mathrm{L}^{-1}$ ( 0.35 to $1.4 \mathrm{ml} \mathrm{L}^{-1}$ ) higher than the LC 50s, when tolerance has been tested (Vaquer-Sunyer and Duarte, 2008). Within estuaries, reduced densities of hogchoker (Trinectes maculates) occur at $<1 \mathrm{mg} \mathrm{L}^{-1}\left(0.7 \mathrm{ml} \mathrm{L}^{-1}\right)$, for spot (Leiostomus xanthurus) at $<1.5 \mathrm{mg} \mathrm{L}^{-1}\left(1.1 \mathrm{ml} \mathrm{L}^{-1}\right)$ and for Atlantic croaker $(\mathrm{Mi}$ cropogonius undulates) at 3 to $5 \mathrm{mg} \mathrm{L}^{-1}\left(2.1-3.5 \mathrm{ml} \mathrm{L}^{-1}\right)$. Lethal oxygen levels are $0.4 \mathrm{mg} \mathrm{L}^{-1}\left(0.28 \mathrm{ml} \mathrm{L}^{-1}\right)$ for hogchoker and $0.7 \mathrm{mg} \mathrm{L}^{-1}\left(0.5 \mathrm{ml} \mathrm{L}^{-1}\right)$ for spot (Pihl et al., 1991); Atlantic croaker in the Gulf of Mexico avoid oxygen concentrations of less than $2 \mathrm{mg} \mathrm{L}^{-1}\left(1.4 \mathrm{ml} \mathrm{L}^{-1}\right)$ (Rabalais et al., 2001a; Craig and Crowder, 2005). In Long Island Sound, 15 out of 18 fish species occur more frequently and at higher densities at sites with $\mathrm{DO}>3 \mathrm{mg} \mathrm{L}^{-1}\left(>2.1 \mathrm{ml} \mathrm{L}^{-1}\right)$ than at sites with $\mathrm{DO}<2 \mathrm{mg} \mathrm{L}^{-1}\left(1.4 \mathrm{ml} \mathrm{L}^{-1}\right)$ (Howell and Simpson, 1994). We note that hypoxia associated with diel cycling may be less effectively avoided by fish and could provide chronic exposure that affects reproduction.

Some invertebrates may experience mortality at $<4 \mathrm{mg} \mathrm{L}^{-1}\left(2.7 \mathrm{ml} \mathrm{L}^{-1}\right)$, with larval stages being the most sensitive (Gray et al., 2002). A meta-analysis by Vaquer-Sunyer and Duarte (2008) revealed that the median oxygen concentration eliciting sublethal effects in 62 invertebrate species (265 experiments) was $2.13 \mathrm{mg} \mathrm{L}^{-1}$ $\left(1.5 \mathrm{ml} \mathrm{L}^{-1} ; 67 \mu \mathrm{M}\right)$. This value is close to the standard definition of hypoxia. Crustaceans are more sensitive to low oxygen than fishes, which are more resistant to hypoxia than molluscs. At $2 \mathrm{mg} \mathrm{L}^{-1}$, crustacean mortality occurs on average within $119 \mathrm{~h}$ of exposure, perhaps explaining why piles of dead crabs or lobsters are often the first sign and a common feature of hypoxia (Officer et al., 1984; Chan et al., 2008). Thresholds are clearly affected by temperature and the presence of $\mathrm{H}_{2} \mathrm{~S}$ (Vaquer-Sunyer and Duarte, 2008).

Thresholds are lower for animals that have evolved in permanently hypoxic settings such as oxygen minimum zones $\left(\mathrm{O}_{2}<0.5 \mathrm{ml} \mathrm{L}^{-1}\right)$, which drape margins of the eastern $\mathrm{Pa}-$ cific, the Arabian Sea and West Africa (Levin, 2003). Within OMZs, invertebrate species composition and diversity are affected at DO concentrations below 0.4 to $0.5 \mathrm{ml} \mathrm{L}^{-1}$ (Levin and Gage, 1998; Levin et al., 2000). Little is known about species-specific thresholds in OMZs but clearly some metazoan populations can survive at oxygen levels close to the limits of detection (e.g. Levin et al., 2003). Studies on Volcano 7 off Mexico (Levin et al., 1991) and the Pakistan margin (Levin et al., 2009) suggest that multispecies macrofaunal communities occur down to an oxygen threshold of around $0.1 \mathrm{ml} \mathrm{L}^{-1}$, but exceptions (where animals thrive at lower levels) have been found off Peru (Levin et al., 2002) and recently off India (Kitazato et al., unpublished data).

The severity of hypoxia experienced by coastal benthic ecosystems is determined by the nature of the exposure in addition to the actual DO concentrations. At the community and ecosystem level, the area affected, the frequency and duration of exposure and the evolutionary history of exposure will all determine the "severity" of impacts and the nature of the response, making prediction of standard successional patterns difficult (Conley et al., 2007).

\section{Regional studies of benthic responses}

\subsection{Estuaries and bays}

Estuarine hypoxia, where present, is most often seasonal, due to increased temperature and salinity stratification between late spring and early fall. Exposure to low oxygen conditions may be aperiodic (not every year; lasting for tidal cycles, days or weeks), episodic (following flooding) and restricted to specific regions (a tributary), so that normoxic refugia may remain elsewhere in the estuarine complex. Estuaries are also subject to harsh extremes of salinity and temperature. In studies of multiple stressor effects on macrofaunal distribution and abundance, dissolved oxygen explains more of the variability than temperature or salinity (Rainer and Fitzhardinge, 1981; Flemer et al., 1999). In addition, organic loading often interacts with DO, and together they explain much of the variation in species presence and density (Flemer et al., 1999). Factors such as reduced solar radiation 
(reducing phytoplankton oxygen production), reduced tidal range (enhancing haline stratification), and precipitation (inducing runoff) can contribute to estuarine hypoxia in tidally mixed estuaries.

Detailed lists of estuaries and bays subject to humaninduced hypoxia and faunal responses are summarized in Diaz and Rosenberg (1995, 2001, 2008) and Gray et al. (2002). The majority of hypoxic estuaries are reported from the North Atlantic Ocean and adjacent seas (Diaz and Rosenberg, 2008). Over $46 \%$ of US estuaries are subject to seasonal hypoxia in one or more localized regions (Gray et al., 2002; Bricker et al., 2007). Of these, the majority occur on the US East and Gulf Coasts. The US West Coast appears more resistant, although hypoxic events have been recorded from Hood Canal (Puget Sound), Los Alamitos and Newport Bay, with nutrient enrichment implicated. Estuarine hypoxia is of widespread concern because estuaries support major shellfisheries (oysters, scallops, clams), provide nursery habitat to numerous finfish and shellfish species harvested commercially, and are key sites for aquaculture.

\subsubsection{Chesapeake Bay}

Chesapeake Bay is one of the largest estuaries in North America, with a length of $320 \mathrm{~km}$. Episodic hypoxia has occurred in Chesapeake Bay since at least 1600 and seasonally since 1900 (Zimmerman and Canuel, 2002; Willard and Cronin, 2007; Gooday et al., 2009). Seasonal hypoxia increased in extent, duration and intensity during the 20th century (Breitburg et al., 2001; Cronin and Vann, 2003, Hagy et al., 2004).

Hypoxia is restricted to the mesohaline regions within the main stem below the pycnocline, and to tributaries such as the Patuxent and Rappahanock Rivers. When the water column is stratified in summer, about $40 \%$ of Chesapeake Bay lies below the pycnocline. The volume of hypoxic water in summer has tripled in the last 40 years and may comprise up to $25 \%$ of the mainstem Bay waters (Hagy et al., 2004). Sediment laminations occur in the deep central bay sediments, indicating that macrofauna are absent and permanent hypoxia may have existed for $\sim 100$ years (Schaffner et al., 1992).

Demersal dwellers and feeders, such as blue crabs, croaker and spot, are particularly susceptible to the effects of hypoxia (Caddy, 1993). Death of crabs in pots, disappearance of crabs in deep water below 4-6 m, and shoaling of crabs during summer have been noted since the 1950s (Officer et al., 1984). In Chesapeake Bay bottom fishes experience habitat compression and potentially reduced access to food (Officer et al., 1984; Breitburg, 1992; Breitburg et al., 2001). However, macrobenthos experiencing hypoxia in the York River migrate to the sediment-water interface and may enhance, at least temporarily, food supply for higher trophic levels (Pihl et al., 1991, 1992).

The combined factors of extensive overfishing, diseases (Perkinsus marinus and Haplosporidium nelsoni), and oxy- gen depletion have had cascading consequences for the bay's ecosystem. Oyster reefs in particular have been decimated in the shallower waters of Chesapeake Bay. In the lower Rappahannock, some oysters have suffocated during hypoxic events, yielding "black bottoms" (Officer et al., 1984; Breitburg et al., 2001). Loss of oysters led to diminished filtration of phytoplankton and consequently reduced light transmission and declines in submerged aquatic vegetation (Newell, 1988; Newell and Koch, 2004). Loss of oyster reef substrates required for benthic life stages of sea nettles led to declines in this key plankton predator that controls ctenophores within the Bay (Breitburg and Fulford, 2006). Bottom-dwelling fishes on the remaining viable oyster reefs were often killed during intrusions of hypoxic water into shallower waters. (Officer et al., 1984; Breitburg, 1992; Breitburg et al., 2001).

The response of benthic communities to hypoxia depends on the severity in terms of DO concentrations, persistence, and temporal sequence. Near total faunal depletion in summer has been recorded for over 30 years in parts of the Patuxent estuary (Mountford et al., 1977; Holland et al., 1977, 1987), followed by fall recolonization. At oxygen concentrations $<1.4 \mathrm{ml} \mathrm{L}^{-1}$, macrobenthic communities in the Rappahannock River show reduced species diversity (50\% lower), lower biomass (70\% lower), and loss of deep-dwelling, longlived species (Dauer et al., 1992). Shallow-dwelling, shortlived opportunist species dominate under hypoxic conditions. These include the polychaetes, Paraprionospio pinnata, Polydora ligni, Streblospio benedicti, Mediomastus ambiseta, Leitoscoloplos fragilis, Glycinde solitaria, Eteone heteropoda and Asabellides oculata, and the bivalve Mulinia lateralis (Dauer et al., 1992).

In the York River, benthos was resistant to periodic hypoxia $\left(0.2-0.8 \mathrm{ml} \mathrm{L}^{-1}\right.$ ) of short (6 to $14-\mathrm{d}$ ) duration that affects mainly areas deeper than $9 \mathrm{~m}$. There were few permanent effects of hypoxia on macrobenthos (Dauer et al., 1992). Epifaunal communities tolerated hypoxic events of up to 1 week in the York River but exhibited behavioral responses including migration up in the water, development of resting stages in sessile taxa, and reduced feeding and growth by mobile taxa (Sagasti et al., 2001). Evidence of long-term changes in benthos of the York River suggests that hypoxia has shaped the benthic communities (Boesch et al., 1976). Observations of macrobenthic and epibenthic resistance and resilience to short-term hypoxia (Pihl et al., 1991; Dauer et al., 1992; Sagasti et al., 2001) have led to speculation of longterm conditioning of the community to episodic oxygen depletion (Diaz and Rosenberg, 1995).

\subsubsection{Changjiang (Yangtze River) estuary and inner shelf of the East China Sea}

The Changjiang (Yangtze River) is among the five largest rivers in the world with $928.5 \times 10^{9} \mathrm{~m}^{3} \mathrm{yr}^{-1}$ of water discharged historically, and $0.4-0.5 \times 10^{9}$ tons $\mathrm{yr}^{-1}$ of sediment (Qu et al., 2005). The river is ca. $6400 \mathrm{~km}$ in length with 
a drainage area of $1.81 \times 10^{6} \mathrm{~km}^{2}$. In the East China Sea, the dilute riverine waters (i.e. river effluent plumes) can disperse over $\sim 10^{4} \mathrm{~km}^{2}$ across the broad shelf in summer when the Changjiang reaches its maximal water discharge (e.g. 40$50 \times 10^{3} \mathrm{~m}^{3} \mathrm{~s}^{-1}$ ). Water circulation in the East China Sea is dominated by complex interactions of water masses and/or currents under the East Asia monsoon climate, including the Kuroshio Surface (KSW) and Sub-surface (KSSW) waters, Taiwan Strait Warm Water (TSWW), East China Sea Coastal Current (ECSCC) and Changjiang Diluted Water (CDW) (cf. Zhang and Su, 2006). These play a crucial role in regulating biogeochemical processes (e.g. hypoxia) on the shelf (Zhang et al., 2007).

Seasonal hypoxia off the Changiiang Estuary is found in summer and sometimes early autumn (i.e. July-September), presumably owing to the stratification that is induced by the buoyancy effect following increase in riverine water influx and high production in surface waters fueled by terrestrial inputs of nutrients. The hypoxic water (i.e. $\mathrm{DO} \leq 1.4 \mathrm{ml} \mathrm{L}^{-1}$ ) is mainly constrained near the $20-75 \mathrm{~m}$ isobath about 10 $20 \mathrm{~m}$ beneath the sea surface, with a minimum DO level of ca. $0.35 \mathrm{ml} \mathrm{L}^{-1}$. Over the last several decades the area of hypoxia off the Changjiang Estuary has tended to increase by a factor of 5-10. The hypoxic area in the inner shelf of the East China Sea was ca. $1800 \mathrm{~km}^{2}$ in August of 1959 , approximately $13700 \mathrm{~km}^{2}$ in August 1999 (Li et al., 2002) and $>15400 \mathrm{~km}^{2}$ in August 2006 (Zhu, 2007). Owing to the very dynamic character of circulation in the East China Sea, the coastal hypoxia off the Changjiang Estuary has strong temporal and spatial variability. The center or core of hypoxia, where minimal DO was observed in near-bottom waters, ranges from $29^{\circ} \mathrm{N}$ to $33^{\circ} \mathrm{N}$ in the area of the $40-50 \mathrm{~m}$ isobaths. Sometimes, two hypoxic cores can be identified offshore of the Changjiang Estuary (Li et al., 2002).

Total organic carbon (TOC) of bottom sediments (i.e. 0$5 \mathrm{~cm}$ ) can be as low as $0.1-0.3 \%$ in areas affected by seasonal hypoxia off the Changjiang Estuary, then increase to $0.5-1.0 \%$ further offshore. Similarly, Chl- $a$ in bottom sediments is $50-100 \mathrm{ng} \mathrm{g}^{-1}$ (dry weight) in areas of summer hypoxia, whereas it can be $200-400 \mathrm{ng} \mathrm{g}^{-1}$ in offshore regions (Zhu, 2007). The benthic fauna in this region is composed of Polychaeta (e.g. Glycera chirori), Crustacea (e.g. Callianassa japonica), Echinodermata (e.g. Ophiura sarsii vadicola) and Mollusca (e.g. Thyasira tokunagai) (Tang, 2004). Seasonal hypoxia in this region causes changes in the species abundance and community structure of benthic fauna, with impaired function of the East China Sea ecosystem via foodweb alterations. Abundance of sessile species that have limited mobility can be considerably reduced when summer hypoxia prevails in the water column. The densities of sessile species do not fully recover in late autumn after hypoxia disappears. At this time strong mixing and water column instability associated with increasing northeast winds may prevent settlement. This is in contrast to the open shelf area outside the hypoxic waters, where animal abundance is higher but exhibits less seasonal variability. The outer shelf meiofaunal (i.e. $<0.5 \mathrm{~mm}$ ) abundance in surface sediments (i.e. $0-5 \mathrm{~cm})$ is depressed $\left(0.5-1.0 \times 10^{6}\right.$ individuals $\mathrm{m}^{-2}$ [ $=500-1000$ ind $\left.10 \mathrm{~cm}^{-2}\right]$ ) but doubles in autumn when hypoxia starts to fade owing to wind-induced vertical mixing; higher meiofaunal abundance (e.g. $2.0 \times 10^{6}$ ind m$^{-2}$ [2000 ind $10 \mathrm{~cm}^{-2}$ ] occurs in areas where normoxic conditions dominate in the water column (Tang, 2004). Macrobenthic densities in hypoxic surface sediments reach 100 200 ind $\mathrm{m}^{-2}$ in spring before the development of seasonal hypoxia, but are $<100 \mathrm{ind}^{-2}$ in autumn when the normoxic conditions recover; outside the hypoxic area abundances are 2-3 times higher (Zheng et al., 2003; Tang, 2004, 2006).

Fish species dwelling in near-bottom waters avoid and/or escape from the hypoxic conditions offshore of the Changjiang Estuary. However, because this region is a traditional spawning and hatching grounds for some economically important fish species (e.g. Trichiurus lepturus, Larimichthys polyacti and Portunus trituberculatus), persistent hypoxia in summer can cause damage to early life-history stages, leading to reduction of recruitment of crucial marine resources (Zheng et al., 2003; Qu et al., 2005). Adults of benthic invertebrates and fish exhibit higher biomass outside the hypoxic zone, with aggregations along the fringe of normoxic waters. Densities (i.e. $\mathrm{kg} \mathrm{h}^{-1}$ of trawling) of yellow croakers, hairtail and crabs in the hypoxia region off the Changjiang Estuary can be 5-fold lower than in normoxic areas further offshore on the shelf (cf. Tang, 2006). Hypoxia in this region interacts with eutrophication induced by nutrient enrichment from land, species invasion from ballast waters, and over-fishing, affecting the sustainability of the ecosystem in the East China Sea Shelf. Collapse of the benthic fauna caused by hypoxia has led to a pelagos-dominated system off the Changjiang Estuary (Zheng et al. 2003; Tang, 2006).

\subsection{Fjords and enclosed seas}

Enclosed water bodies such as fjords, lochs, basins and shallow seas often exhibit stratification of temperature and/or salinity with oxygen depletion in deeper waters. When thermal stratification is most intense during summer, hypoxia can be seasonal, persisting for weeks to months.

\subsubsection{Fjords}

Anoxia is usually a local event and does not encompass the whole water body. Mussel bed presence will enhance oxygen depletion, due to enhanced oxygen consumption. Summer anoxia typically elicits a mortality sequence. Motile species such as fish will move away from the anoxic areas. Somewhat less mobile crustaceans such as shrimp and crabs die first, followed by lamellibranch molluscs, and snails, with polychaetes often most resistant (Jørgensen, 1980). Sulfide oxidizing bacteria (Beggiatoa, Thiovulum) form mats at the 
sediment-water interface where both sulfide and oxygen are present. Areas less affected provide source organisms for recolonization.

Oxygen-tolerant taxa in NE Atlantic fjords typically include Heteromastus filiformis, Melinna cristata, Spiophanes kroyeri, Abra nitida, and Thyasira equlis. Thyasira sarsi, Amphiura chiajei, A. filiformis, and Capitella capitata are dominant at deeper stations, although they require higher oxygen levels (Josefson and Widbom, 1988; Nilsson and Rosenberg, 2000). Indices that combine animal abundance measures with sediment structure and redox potential discontinuity (RPD) depth provide good characterization of the successional response to hypoxia by fjord benthos (Nilsson and Rosenberg, 2000)

Fjords and lochs have limited flushing, and thus are susceptible to hypoxia through human inputs of organic matter via fish farming, pulp mill effluent, and sewage. Salmon farming is a common practice in high-latitude fjords and lochs. When flushing is restricted or infrequent, organic matter from the farms will sink to sediments and cause high oxygen consumption (Gillibrand et al., 1996), depleting the oxygen in bottom waters. In lochs such as Loch Ailort, subject to farming for several decades, the fish food may contribute up to $50 \%$ of the total particulate organic carbon (POC) supply. Scalibregma inflatum was the dominant taxon beneath fish farms in Loch Ailort. Mellina cristata, with the ability to build long tubes up into the water, was dominant in the Gullmarfjord after extended hypoxia. Tube extension may increase turbulence and enhance oxygen supply (Nilsson and Rosenberg, 2000). The benthic fauna was eliminated near a sulphite pulp mill in the upper reaches of the Gullmar Fjord (Leppäkoski, 1975).

\subsubsection{Black Sea}

The Black Sea drains areas from 17 countries, receiving input from Europe's 2nd and 3rd largest rivers, the Danube and Dnieper (Mee et al., 2005, Shapiro et al., 2006). The shallower shelf of the Black Sea has been subject to extensive eutrophication while hypoxia in the deep basin is natural and has persisted for much longer periods. Prior to 1973, the Black Sea shelf $\left(50000 \mathrm{~km}^{2}\right)$ was dominated by a red alga Phyllophora nervosa that supported a rich assemblage of 118 invertebrates and 47 fish species. Along a vertical oxygen gradient in the northwestern Black Sea there is a transition from Mytilus galloprovincialis $(62 \mathrm{~m})$ to Modiolus phaseolinus biocoeneses at $100 \mathrm{~m}$. The high filtration rates of the mussels regulate phytoplankton biomass. During the 1960s agricultural and lifestyle transformations in countries surrounding the Black Sea led to increased agricultural, animal, industrial and human waste inputs to surface waters. Eutrophication and increased phytoplankton biomass resulted in light limitation that led to the die off of the macroalgal mats. As eutrophication increased, mussels were unable to regulate phytoplankton blooms and massive buildup of detritus generated excessive oxygen demand (Mee et al., 2005). In 1973 the northwestern shelf experienced $3500 \mathrm{~km}^{2}$ of summer hypoxia as a result of eutrophication. By 1978 this had expanded to $30000 \mathrm{~km}^{2}$. By 1989, mass mortalities of benthos had occurred (Zaitsev, 1992) and in 1990 the "dead zone" encompassed $40000 \mathrm{~km}^{2}$. Anoxia led to further release of phosphorus and ammonium from sediments, contributing additional nutrient loading. The collapse of the benthic system led to a pelagic-dominated system. Overfishing and species invasion by the comb jelly Mnemiopsis leydi, which attained biomass up to $5 \mathrm{~kg} \mathrm{~m}^{-2}$, further impaired function of the ecosystem (Vinogradov, 1992).

Economic failure and social change in the late 1980s led to a dramatic reduction in nutrient and waste inputs to the Black Sea, and ultimately to a shift in political and management regimes. A variety of treaties and altered practices have greatly reduced eutrophication in the Black Sea and provided valuable information about capacity for ecosystem recovery. Benthic studies suggest limited recovery within 6 years, with some macroalgae and mussels present (Mee et al., 2005). However, humans cannot control all aspects of Black Sea hydrography and oxygenation. External forcing from the continental margin waters and from climate events are important in this system, along with nutrient loads. Episodic phytoplankton blooms result when cold, nutrient-rich waters from the northern slope and shelf mix with the cold intermediate layer. Winter production may rival the eutrophic production (Sorokin, 2002). In 2001 late rainfall and high temperatures triggered a hypoxic event on the northwestern shelf (Mee et al., 2005).

Along a vertical oxygen gradient in the northwestern Black Sea, elevated meiofauna density occurs at the transition from oxic to anoxic bottom waters, which begins around $130 \mathrm{~m}\left(<5 \mu \mathrm{M} \mathrm{O}_{2}\right.$, Wenzhofer et al., 2002). Some hypoxiatolerant species persist between 130 and $185 \mathrm{~m}$ where the transition zone is subject to instability and appears to fluctuate vertically (Gulin and Kovalevsky, 2008). The oxic/anoxic transition interacts with methane seepage creating a complex geochemical setting inhabited largely by microbes, Foraminifera and nematodes (Sergeeva and Gulin, 2007). Larvae and adults of the polychaetes Protodrilus sp. and Victorniella zaikai (a chrysopetalid) are abundant in the transition water column and sediments, respectively (Sergeeva et al., 1999).

\subsubsection{Baltic Sea}

The Baltic Sea is a large brackish body of water with several basins separated by sills. Hypoxia first occurred in the Baltic Sea after its transition from fresh water to brackish water about 8000 cal. yr BP (Sohlenius et al., 2001). Hypoxia was intermittently present through the Holocene (Zillén et al., 2008), and persistently present since about 1900 (Fonselius, 1981). The Baltic Sea now has a permanent halocline that prevents mixing and oxygenation of water (Andersin et 
al., 1978). The occurrence of hydrogen sulfide at depth in the Baltic fluctuates with flushing by Kattegat waters, with hydrogen sulfide present as shallow as 110 to $115 \mathrm{~m}$ (Fonselius, 1981). During the 20th century, nitrogen increased fourfold and phosphorus inputs to the Baltic increased eightfold (Larsson et al., 1985), which led to eutrophication and worsening hypoxia/anoxia. There is an early history of extreme fluctuation in bottom-water oxygen concentrations $(>80 \mathrm{~m}$ ) from both natural cases and human-induced eutrophication. Hydrogen sulfide was documented as early as 1931 in the Gotland Deep, and macrobenthos were reported absent from the Bornholm Basin in 1948. Episodic flushing events involving North Sea water occurred in the 1950s and 1960s causing oxygenation $\left(3-5 \mathrm{ml} \mathrm{L}^{-1}\right)$ followed by rapid drops in oxygen to near 0 in the Bornholm Basin (Tulkki, 1965, Leppäkoski, 1975). During these events the normally lowdiversity macrobenthos (e.g., 7-8 species) became heavily dominated in numbers and biomass by one or a few hypoxiatolerant species (e.g. Scoloplos armiger in 1965; Capitella sp. in 1967). While macrobenthos biomass increased above the halocline, severe hypoxia and anoxia developed below (Elmgren, 1989), causing elimination of bioturbating macrofauna and formation of laminated sediments over large areas of seafloor (Schaffner et al., 1992).

In the eastern Gotland Deep biological features and abiotic factors result in distinct faunal zones (Olenin, 1997). Up to 50 species were found at oxygenated depths $<30 \mathrm{~m}$, only 11-14 species were present in hypoxic waters from 50 to $124 \mathrm{~m}$, and no species were recovered between 124 and $140 \mathrm{~m}$. High biomass in shallow areas was associated with a hard-bottom community of Mytilus edulis and with Macoma balthica in sediment (Olenin, 1997). Among the hypoxia-tolerant taxa found at deeper depths are the ophiuroid Amphiura sarsi, the priapulid Halicryptus spinulosus, the peracarid crustaceans Saduria entomon, Diastylis rathkei and Pontoporeia femorata, the bivalve Macoma balthica, and the polychaetes Pygospio elegans and Scoloplos armiger. Hypoxia-tolerant ostracods include Cyprideis torosa, Heterocyprideis sorbyana, and Candona neglecta. These taxa reflect either omnivorous mobile (swimming) taxa, i.e. the crustaceans, or shallow infaunal deposit feeders. Both groups have minimal bioturbation capacity.

\subsection{Continental shelves}

\subsubsection{Chilean shelf}

Hypoxia on the outer Chile shelf is associated with Equatorial subsurface water. The influence of this water mass is greatest off northern Chile, where more or less permanent hypoxia occurs from the inner shelf to $400 \mathrm{~m}$. Off central Chile, the outer shelf is seasonally hypoxic to $41^{\circ} \mathrm{S}$ due to upwelling in shallow water during spring and summer (Sellanes et al., 2003, 2007). Thick mats of sulfide oxidizing Thioploca and Beggiatoa are key features on the Chile shelf during nor- mal summer hypoxia. These bacteria attain a wet weight of $1 \mathrm{~kg} \mathrm{~m}^{-2}$ between 50 and $100 \mathrm{~m}$ water depth (Gallardo, 1963, 1977). Associated with the bacteria mats are nematodedominated meiofaunal assemblages (Neira et al., 2001b; Sellanes et al., 2003). Macrofauna are abundant (e.g. up to $73900 \mathrm{ind} \mathrm{m}^{-2}, 68.4 \mathrm{~g} \mathrm{~m}^{-2}$ wet wt.) but diversity is low (Sellanes et al., 2007). Body size is reduced under hypoxic conditions on the Chile shelf (Quiroga et al., 2005). Most of the macrofauna are annelids and about half are represented by the polychaete Paraprionospio pinnata. This species is highly adapted for low oxygen conditions, with elaborate branchial structures that enhance oxygen diffusion and enzymatic adaptations for anaerobic metabolism (González and Quinoñes, 2000; Quiroga et al., 2007). Mediomastus branchiferus, Aricidea pigmentata, Nephtys ferruginea and Cossura chilensis, combined with the amphipod Ampelisca araucana, form most of the remaining macrofauna. It is hypothesized that uptake of $\mathrm{H}_{2} \mathrm{~S}$ by the large filamentous bacteria acts to detoxify the setting, protecting annelid prey and their predators such as red crabs (Gallardo et al., 1994).

There is a strong coupling of upwelling, primary production, oxygen budgets and benthic communities on the Chile shelf; this has been best documented off Concepcion, Chile $\left(36^{\circ} \mathrm{S}\right)$. Bacterial mat cover and biomass is greatest after consecutive years of upwelling-favorable, highly productive, La Niña-like conditions; Thioploca thrives at DO levels between 0.2 and $0.3 \mathrm{ml} \mathrm{L}^{-1}$ (Gutiérrez et al., 2000). During El Niño years, when primary production declines and the shelves become better oxygenated (Schaffer et al., 1999), Thioploca biomass is depressed and densities of the tubedwelling P. pinnata decline (Gutiérrez et al., 2000; Sellanes et al., 2007). Larger-bodied, subsurface, bioturbating species (e.g. Cossura chilensis) increase in density and there is an overall deepening of faunal activity within the sediments (Gutiérrez et al., 2000; Sellanes et al., 2003). This leads to greater irrigation, and more sediment reworking (Gutiérrez et al., 2000).

Meiofauna show parallel trends off central Chile during El Niño events. Meiofaunal abundance and biomass increase, dominance by nematodes is diminished, remaining nematodes dwell deeper in the sediments, and harpacticoid copepods increase in abundance (Neira et al. 2001b; Sellanes et al., 2003; Sellanes and Neira, 2006). Overall meiofaunal abundance is positively correlated with bottom-water oxygen concentration. The cumulative effect of El Niño is to attenuate seasonality and create better oxygenated, winterlike conditions on the shelf throughout the year, with effects on the benthic community lasting up to five years beyond the cessation of detectable climate shifts.

\subsubsection{Peru margin}

Long-term monitoring of shelf bacteria and metazoans in sediments off Peru $\left(12^{\circ} \mathrm{S} ; 94 \mathrm{~m}\right)$ shows variations in bottom-water oxygen concentrations and community structure driven remotely by coastal trapped waves originating in 
the Equatorial region; these are often but not always associated with ENSO cycles. There are three community "states". Prevailing conditions involve anoxia-hypoxia $(\mathrm{DO}<10 \mu \mathrm{M})$ with few macrofauna and domination of biomass by nematodes. During intermediate oxygenation (10-20 $\mu \mathrm{M})$, sulfide oxidizing bacterial mats (Thioploca spp.) make up much of the biomass. Under higher oxygenation levels associated with strong El Niño events $(>40 \mu \mathrm{M})$, macrofauna are dominant. Macrofaunal dominance may persist long after reformation of hypoxia, apparently due to the bioturbation activity of nemerteans and enteropneusts, which mixes what little oxygen is available into the sediments (Gutiérrez et al., 2008). Thus different oxygen levels are not always linked to distinct assemblages and transitions are observed frequently.

Shallow waters in the Bay of Ancon, Peru $\left(11^{\circ} \mathrm{S}\right)$ are subject to frequent hypoxia at $15 \mathrm{~m}$ and nearly permanent hypoxia (and sometimes anoxia) at $34 \mathrm{~m}$. Macrobenthos during "normal" (non El Niño) years are characterized by low faunal

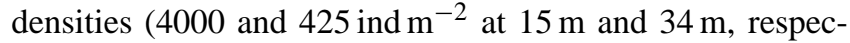
tively), low biomass $\left(<1.08 \mathrm{~g}\right.$ and $0.2 \mathrm{~g}$ ash free dry wt. $\left.\mathrm{m}^{-2}\right)$, and low numbers of species (3-17 and 0-6) (Tarazona et al., 1988a, 1988b). The numerically dominant taxa were Owenia collaris, Magelona phyllisae, Chaetozone sp. and Phoronis sp. at $15 \mathrm{~m}$ and Paraprionospio pinnata, M. phyllisae, Chaetozone sp. and Leitoscoloplos chilensis at $34 \mathrm{~m}$ (Tarazona et al., 1988a). Since monitoring of macrobenthos began in 1981 there have been four El Niño events that have raised temperatures and oxygenated the inshore waters. The community response consistently involved nearly immediate, dramatic elevation of diversity and reduced dominance, with colonization of local species (Tarazona et al., 1988a, 1988b; Arntz et al., 2006). While density and biomass increases followed oxygenation in some cases, this response was not consistent, possibly due to increased predation by megafaunal species that also recolonized. Sometimes high macrofaunal densities continued following the return of hypoxia. Similar results have been obtained for macrofauna in the Bay of Independencia $\left(14^{\circ} 20^{\prime} \mathrm{S}\right)$ (Tarazona et al., 2001; Arntz et al., 2006). Massive wash-ups of the Humboldt squid (Dosidicus gigas) (Fig. 6c) that occur off California, Oregon and as far north as British Columbia may also be related to inshore movement of low-oxygen water.

Numerous fisheries species on the central Peru shelf respond positively to oxygenation events during El Niño. These include the scallop (Argopecten purpuratus), octopus (Octopus fontaneanus), purple snail (Thais chocolata), and multiple species of shrimp (Xiphopenaeus riveti, Sicyonia disdorsalis and several Penaeus spp.). Other species responding positively after El Niño events include barnacles (Pollicipes elegans) and the hake (Merluccius gayi peruanus) (Arntz et al., 1988; Espino et al., 1985).

In contrast to the central Peru dynamics, at sites further north on the Peru coast (Paita $05^{\circ} \mathrm{S}$, and San Jose $06^{\circ} 45^{\prime} \mathrm{S}$ ) time series of macrobenthos at $35-\mathrm{m}$ and $65-\mathrm{m}$ water depth reveal a negative response to El Niño conditions. Most species, except Paraprionospio pinnata, declined in density during the 1997-1998 El Niño. This situation was attributed to increased river runoff and reduction in food supply (Gutiérrez et al., 2005).

\subsubsection{Oregon shelf}

Summer hypoxia on the inner Oregon shelf $(<50 \mathrm{~m})$ is a recent occurrence (Grantham et al., 2004; Chan et al, 2008) and most benthic responses have yet to be quantified. Hypoxia was first reported in July to September 2002, when oxygen concentrations dipped to $0.21-1.57 \mathrm{ml} \mathrm{L}^{-1}$ over the shelf, and mortalities of schooling and benthic rockfishes were recorded (Grantham et al., 2004). Mass mortality of brachyuran crabs and absence of fishes was recorded by ROV surveys in 2006, when hypoxia covered $3000 \mathrm{~km}^{2}$, occurred over $80 \%$ of the water column, and reached within $2 \mathrm{~km}$ of shore (Chan et al., 2008). The 2006 hypoxia event extended over much of the Washington shelf as well (Connolly et al., 2008). In 2007 a number of long-lived species such as large asteroids, holothurians and echinoid urchins remained absent from the system. In summer 2006 (the most intense hypoxic period to date), the benthic community at $100 \mathrm{~m}$ off Astoria (oxygen concentration $1.67 \mathrm{ml} \mathrm{L}^{-1}$ ) exhibited high dominance by Mediomastus sp. and Sphaerosyllis sp. with Prionospio sp., lumbrinerids, magelonids and bivalves all abundant ( $>5 \%$ representation) (Levin, unpublished). No comparison data for normoxic years are available.

\subsubsection{California shelf}

Recent analyses of the California Cooperative Fisheries Investigation (CalCOFI) oxygen time series off southern $\mathrm{Cal}-$ ifornia by Bograd et al. (2008) have documented declining oxygen concentrations over the past 22 y (1984-2006). At 200-300 m, the oxygen content of the water has declined by $20 \%$ to $30 \%$, with a shoaling of the hypoxic boundary $\left(1.42 \mathrm{ml} \mathrm{L}^{-1}\right)$ of up to $90 \mathrm{~m}$ within inshore regions of the southern California Current system. Both increased stratification from warming, and advection of low-oxygen equatorial waters are proposed to contribute to oxygen declines. During April 2008, oxygen was measured below $2 \mathrm{ml} \mathrm{L}^{-1}$ at $100 \mathrm{~m}$ depths and between 1 and $2 \mathrm{ml} \mathrm{L}^{-1}$ over much of the inner southern California shelf (J. Wilkinson, personal communication). McClatchie et al. (personal communication), suggest that similar oxygen declines associated with shoaling of the OMZ were also observed off California in 195060 and that hypoxia at $200-300 \mathrm{~m}$ is common in summer. The outer shelf provides habitat for several valuable rockfish (Sebastes spp.). New analyses reveal that $37 \%$ of the rockfish conservation area at $180-240 \mathrm{~m}$ is hypoxic during a normal summer, but this may increase to $55 \%$ during El Niño years when the California undercurrent, carrying saline low-oxygen water, is strengthened (McClatchie et al., personal communication). While the fish can migrate inshore, 
this causes loss of habitat for populations already stressed by overfishing. There are few outer-shelf fish or invertebrate surveys that track changes in animal distributions in response to hypoxia. However, many changes in animal distributions are noted off California during El Niño (Arntz et al., 2006); some of these might be driven by responses to oxygen depletion in addition to warming.

Alta California (USA) has no records of shelf anoxia, but during June 2007, inshore anoxia was recorded over a $5 \mathrm{~km}$ stretch of coastline at Erendira, a strong upwelling region off Baja California, south of Ensenada, Mexico. Most animals died and a walkout involving many tons of lobsters was observed, similar to events off Nambia. The anoxic event was attributed to a combination of upwelling, intrusion of deep, subtropical salty, low-oxygen waters, and red tide conditions (J.M. Hernandez-Ayon et al., pers. comm.). Recent local observations of declining oxygen levels combined with oceanscale records of expanding oxygen minimum zones in the eastern tropical Pacific (Stramma et al. 2008, and in review) suggest that hypoxia may become increasingly common on the Pacific shelves off Oregon, California and Mexico in the coming decades.

\subsubsection{Northern Gulf of Mexico}

The northern Gulf of Mexico hypoxic zone, adjacent to and influenced by the Mississippi and Atchafalaya Rivers, is the second largest zone of human-caused, oxygen-depleted waters in the world's coastal ocean (Fig. 2). River and landscape alterations over two centuries have significantly lessened the buffering capacity of the watershed (Turner and Rabalais, 2003), but anthropogenic additions of nutrients resulted in eutrophication and the development of hypoxia in the last half of the 20th century (Rabalais et al., $2007 \mathrm{a}, \mathrm{b}$ ).

Seasonal hypoxia - spring through early fall - is the result of persistent stratification coupled with the high organic production in overlying surface waters that is fueled by river-derived nutrients (Rabalais et al., 2007a). There is a persistent haline stratification due to the high discharge of the Mississippi River, which, coupled with thermal warming in the spring and summer, intensifies the density differences. The mid-summer extent of bottom-water hypoxia $\left(<2 \mathrm{mg} \mathrm{L}^{-1} ; 1.4 \mathrm{ml} \mathrm{L}^{-1}\right)$ has averaged $13500 \mathrm{~km}^{2}$ since 1985 , and reached its maximal size of $22000 \mathrm{~km}^{2}$ in 2002 . Hypoxic waters are most prevalent at depths between 5 and $45 \mathrm{~m}$.

The responses of the fauna vary, depending on the concentration of dissolved oxygen, but there is a fairly consistent pattern of progressive stress and mortality as the oxygen concentration decreases from 2 to $3 \mathrm{mg} \mathrm{L}^{-1}$ (1.4 to $\left.2.1 \mathrm{ml} \mathrm{L}^{-1}\right)$ to anoxia $\left(0 \mathrm{mg} \mathrm{L}^{-1}\right)$ (Fig. 3). Elasmobranchs (rays and sharks) typically leave the area when oxygen concentrations fall below $3 \mathrm{mg} \mathrm{L}^{-1}$. Other demersal fishes migrate away from the area when oxygen concentrations fall below $2 \mathrm{mg} \mathrm{L}^{-1}$, although drum, red fish and snapper are oc-

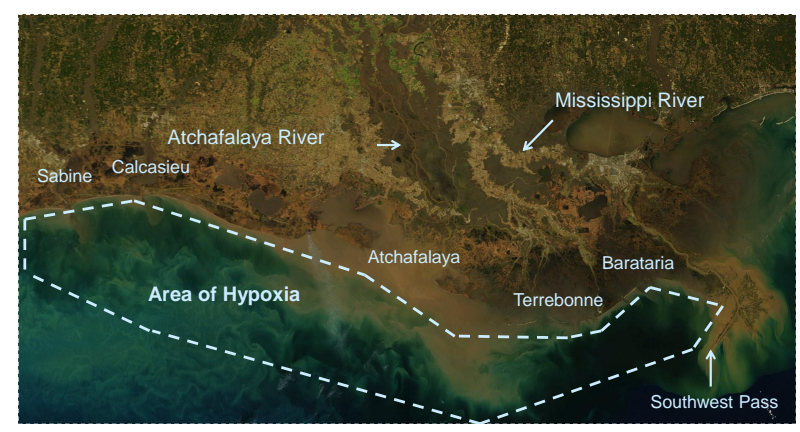

Fig. 2. Hypoxic region and influencing rivers off Louisiana in the northern Gulf of Mexico.

casionally seen by divers when the oxygen concentrations are near $1.5 \mathrm{mg} \mathrm{L}^{-1}\left(1 \mathrm{ml} \mathrm{L}^{-1}\right)$ and the layer of hypoxic water is not thick (N. Rabalais, personal observation). Demersal fishes and crustaceans can die en masse when hypoxic water masses trap them near shore and there is no escape. Demersal invertebrates are seldom caught in bottom trawls when the oxygen levels fall below $2 \mathrm{mg} \mathrm{L}^{-1}\left(1.4 \mathrm{ml} \mathrm{L}^{-1}\right)$ (Pavela et al., 1983; Renaud, 1986), but are routinely seen in remotely-operated vehicle (ROV) tapes at oxygen concentrations below that level (Rabalais et al., 2001a). Some penaeid shrimp and stomatopods were observed at oxygen levels as low as 1.7 to $1.8 \mathrm{mg} \mathrm{L}^{-1}\left(1.2-1.3 \mathrm{ml} \mathrm{L}^{-1}\right)$ but never below $1.5 \mathrm{mg} \mathrm{L}^{-1}\left(1 \mathrm{ml} \mathrm{L}^{-1}\right)$. Stomatopod presence in hypoxic waters as low as $1.5 \mathrm{mg} \mathrm{L}^{-1}$ is consistent with the results of Pihl et al. (1991) who indicated that Squilla empusa first adapted physiologically to hypoxia and then migrated as hypoxia became more severe, a trend consistent with its more stationary and territorial behavior.

As the oxygen level decreases from 1.5 to $1 \mathrm{mg} \mathrm{L}^{-1}$ (1 to $0.7 \mathrm{ml} \mathrm{L}^{-1}$ ) bottom-dwelling organisms exhibit stress behavior (Rabalais et al. 2001a). Crabs (e.g. Libinia sp., Persephona sp.) and sea stars (Astropecten sp.) climb on top of high spots, such as burrow excavation mounds. Brittle stars emerge from the sediment and use their arms to raise their disks off the substrate. Burrowing shrimp (Alpheus sp.) emerge from their burrows, and gastropods (Oliva sayana, Terebra sp., Cantharus cancellarius and Distorsio clathrata) move through the surface sediments with their siphons extended directly upward. Large burrowing anemones $(\mathrm{Ce}$ rianthus sp.) become partly or completely extended from their tubes and lie on the substrate, in a flaccid and nonresponsive condition. Polychaete worms emerge from the substrate and lie motionless on the surface (e.g. Chloeia viridis and Lumbrineris sp.). These behaviors are presumed to position the organisms in higher oxygen content waters, even though moving from the safety of the sediments exposes them to greater risk of predation. The presence of large, typically infaunal organisms on the sediment surface, however, supports the idea presented earlier that bottom-feeding fish are excluded from the hypoxic lower water column, unlike in 


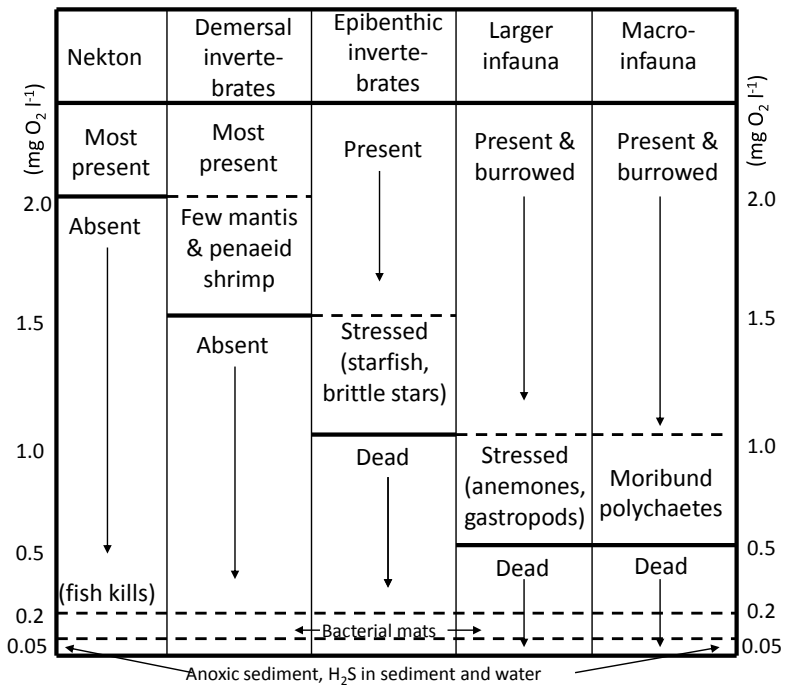

Fig. 3. Progressive changes in fish and invertebrate fauna as oxygen concentration decreases from $2 \mathrm{mg} \mathrm{L}^{-1}\left(1.4 \mathrm{ml} \mathrm{L}^{-1}\right)$ to anoxia $\left(0 \mathrm{mg} \mathrm{L}^{-1}\right)$ on the Louisiana continental shelf (Rabalais et al., 2001a, b).

the York River of Chesapeake Bay where predators move into such areas and feed on stressed infauna (Pihl et al. 1992).

As oxygen levels decrease from 1 to $0.5 \mathrm{mg} \mathrm{L}^{-1}(0.7$ to $0.35 \mathrm{ml} \mathrm{L}^{-1}$ ) even the most tolerant burrowing organisms, principally polychaetes, emerge partially or completely from their burrows and lie motionless on the bottom. Several polychaetes, one hemichordate, one ophiuroid and several cerianthid anemones that appeared lifeless on the bottom became active when they were brought to the surface in sealed containers of ambient water and placed in shallow dishes with ambient water that naturally re-oxygenated by diffusion (Rabalais et al. 2001a). Jørgensen (1980) also found that many of the organisms seen lying on the bottom in hypoxic areas were moribund, not dead. If these organisms survive, they may re-enter the sediment and may partially account for the recolonization of benthos when hypoxia abates. Below oxygen concentrations of $0.5 \mathrm{mg} \mathrm{L}^{-1}\left(0.35 \mathrm{ml} \mathrm{L}^{-1}\right)$ there is a fairly linear decline in species richness, abundance and biomass of benthic macroinfauna (Rabalais et al., 2001b).

Benthic communities in seasonally severe hypoxic conditions on the Louisiana continental shelf are characterized by decreases in species richness, abundance and biomass of organisms relative to similar habitats without low oxygen levels (Rabalais et al., 2001b). Some macroinfauna, including the polychaetes Ampharete and Magelona and sipunculans, are capable of surviving extremely low dissolved oxygen concentrations and/or high hydrogen sulfide concentrations. The abundance of macrofauna during the period of lowest oxygen concentrations are less than comparable areas off the southwestern Louisiana coast, on the Texas shelf, and in the Chesapeake Bay mainstem and tributaries (Rabalais et al., 2001b). Abundances of macroinfauna, primarily opportunistic polychaetes, increase in the fall following the dissipation of hypoxia, but the numbers of individuals can be only slightly greater than the summer depressed fauna and result in no or a negligible increase in biomass. Fewer taxonomic groups characterize the severely affected area throughout the year. Long-lived, higher biomass and direct-developing species are never members of the severely affected community. Suitable feeding habitat (in terms of severely reduced populations of macroinfauna that may characterize substantial areas of the seabed) is thus removed from the foraging base of demersal organisms, including the commercially important penaeid shrimps.

Murrell and Fleeger (1989) surveyed the meiofaunal assemblages at three shallow stations $(8-13 \mathrm{~m})$ over an annual cycle, including severe hypoxia in the summer. Total meiofaunal abundances increased through spring and ranged from approximately 800 to 3800 ind $10 \mathrm{~cm}^{-2}$ before a hypoxic event. Following hypoxia there were dramatic declines in abundance and diversity of major meiofauna taxa (Murrell and Fleeger, 1989). Benthic harpacticoid copepods were least tolerant to low oxygen, while nematodes and kinorhynchs were less affected. Copepods declined from high values of $100-410$ to zero ind $10 \mathrm{~cm}^{-2}$ when hypoxia developed. Nematode abundance ranged from 600 to 3100 ind $10 \mathrm{~cm}^{-2}$ before hypoxia and from 500 to 1100 ind $10 \mathrm{~cm}^{-2}$ after hypoxia. There was clear evidence from settlement traps deployed in the area of hypoxia that nematodes migrated into the water column away from hypoxic sediments and settled to the sediments with the return of normoxic conditions (Wetzel et al., 2001). These same settling traps provided evidence that the polychaete Paraprionospio pinnata delayed settlement and remained in the water column until oxygen values returned to a level above $2.0 \mathrm{mg} \mathrm{L}^{-1}$ (Powers et al., 2001).

At oxygen values below $0.2 \mathrm{mg} \mathrm{L}^{-1}$ but above anoxia $\left(0 \mathrm{mg} \mathrm{L}^{-1}\right)$, various sized patches of "cottony" Beggiatoa mats cover the sediment surface on the Louisiana shelf. Filaments of the bacteria Beggiatoa and other unidentified filamentous bacteria form on the surface of the sediments at oxygen levels up to $1 \mathrm{mg} \mathrm{L}^{-1}$ (L. Duet, Q. Dortch, N. Rabalais, unpublished data). The obvious Beggiatoa mats, observed by ROV video and divers, are present at oxygen concentrations $<0.2 \mathrm{mg} \mathrm{L}^{-1}$. Similar bacterial mats were observed by divers on the inner shelf off Freeport, Texas in June 1979 following a severe hypoxic event (Harper et al., 1981).

\subsubsection{Benguela shelf, West Africa}

The Benguela shelf, extending to $350 \mathrm{~m}$, is among the deepest in the world outside Antarctica (Shannon, 1985). There are three distinct regimes with respect to oxygenation and sulfide production: the inner shelf with extremely oxygen-depleted bottom waters, the oxygen minimum zone on the outer shelf and upper continental slope, and 
the better oxygenated continental slope (below the OMZ) (Brïchert et al., 2003). The Luderitz upwelling cell divides the outer shelf and slope into a northern region, characterized by oxygen minimum waters and a better oxygenated southern zone. Sanders (1969) conducted seminal work on macrofaunal diversity along a transect from Walvis Bay $(100 \mathrm{~m})$ to the open ocean $(2140 \mathrm{~m})$. He documented a 100 -fold increase in density between $100 \mathrm{~m}$ and $200-300 \mathrm{~m}$ water depths and a 10-fold increase in diversity as oxygen shifted from just under 2\% saturation to 11-15\% saturation (Sanders, 1969). Most studies of the Benguela benthic ecosystem response to hypoxia conducted since that time focus on fisheries species (Sakko, 1998) or sediment microbiology (Schulz and de Beer, 2002; Brüchert et al., 2003).

Recent investigations have revealed that the central Benguela outer shelf experiences significant oxygen variability, driven by advection over both seasonal and interannual time scales (Monteiro et al., 2006, 2008; Monteiro and van der Plas, 2006; Brüchert et al., 2006, Mohrholz et al., 2007). The relatively better oxygenated Cape Basin South Atlantic central water and the warm, saline hypoxic Angola Basin Central water provide opposing biogeochemical influences that mix on the shelf after upwelling at Cape Frio and Lüderitz. Hypoxia intensifies from December to May when the poleward flow of the equatorial current strengthens and peaks in June and July due to contributions from in situ oxygen consumption. This seasonality has been intensifying due to warming trends (Monteiro et al., 2008). Interannual variability is also strong, with Benguela Niños shifting the hypoxic boundary vertically, and driving hypoxia to persistent anoxia on the central Benguela shelf (Monteiro et al., 2006). The shape of the shelf has a large influence on the sources and tempo of physical forcing by regulating influence of the ocean-shelf boundary and regional wind-stress driven advection.

Fish assemblages change along latitudinal and depth gradients on the Benguela shelf. The oxygen-depleted central inner shelf (to depths of approximately $150 \mathrm{~m}$ ) is populated almost exclusively by the goby Sufflogobius bibarbatus, but diversity is much higher on the outer shelf (150$300 \mathrm{~m}$ ) where hake and horse mackerel are found in bottom waters. Squid and cuttlefish are present to the south where oxygenation improves (Sakko, 1998). Benthic ostracods also show low diversity in the north and higher diversity to the south, corresponding to differences in water mass oxygenation (Dingle et al., 1995). Decapod crustaceans typically avoid low oxygen. The portunid Bathynectes piperitus avoids the low oxygen concentrations on the shelf but aggregates just below the OMZ at 300-400 m (Abello and Macpherson, 1989). Such aggregations, observed in crabs, shrimp and ophiuroids on different margins, appear to be a common feature of lower OMZ boundaries (Levin, 2003).

Biomass spectra of fishes reveal greater abundance of small species with rapid turnover rates, lower community diversity, reduced importance of elasmobranchs, and declining biomass in the central, most productive shelf areas, relative to less productive regions (Macpherson and Gordoa, 1996). Although oxygen is not mentioned by these authors, it almost certainly is a key agent producing these patterns. The dynamics of hake populations on the shelf and slope are driven largely by oxygen. The two prevalent hake species have different habitat preferences and tolerances to low oxygen; this is reflected in their temporal variability. Merluccius paradoxus moves $\mathrm{N}$ and $\mathrm{S}$ with the better-oxygenated Cape Basin central water. This species resides at the boundary between the equatorial and Cape Basin waters, retaining some access to oxygen but gaining protection from less hypoxia-tolerant predators (Monteiro et al., 2008). In contrast, M. capensis resides on the shelf and through physiological adaptation tolerates relatively lower oxygen. Severe oxygen limitation causes massive biomass fluctuations in this species rather than a redistribution of the population (Monteiro et al., 2008)

The inner Benguela shelf (to 100-125 m water depth) is distinct in having muddy, diatomaceous sediments rich in opal and organic carbon that accumulate at high rates due to elevated productivity. There are measurable sulfide fluxes to the water column, and sediments are also sulfidic (Brüchert et al., 2003). Overlying water is often hypoxic or anoxic with oxygen depletion resulting from in situ degradation of organic matter combined with periodic advection of low oxygen Angola current water. Hypoxic conditions $\left(<0.5 \mathrm{ml} \mathrm{L}^{-1}\right)$ cover almost $4700 \mathrm{~km}^{2}$, which is $55 \%$ of the total shelf, whereas extreme anoxia (oxygen concentrations less than $\left.1 \mu \mathrm{M}\left(=0.023 \mathrm{ml} \mathrm{L}^{-} 1\right)\right)$ occurs over almost $900 \mathrm{~km}^{2}$, roughly $10 \%$ of the total shelf area (Brüchert et al., 2006). There is some disagreement about the extent to which water column oxygen levels on the inner shelf are regulated by sedimentary processes versus external forcing. Both seasonal and decadal variability in oxygen on the shelf are attributed to the influence of external hypoxic boundary conditions (van der Plas et al., 2007; Monteiro and van der Plas, 2006). However, the close match between the combined sediment and water column oxygen consumption versus primary production on the inner shelf supports local, sedimentary regulation (Brüchert et al., 2006).

High rates of sulfate reduction occur within inner shelf sediments (Brüchert et al., 2003) and when sulfate is depleted, methanogenesis occurs. Sulfide removal is bacterially mediated by large, sulfide oxidizers, including Beggiatoa spp. and Thiomargarita namibiensis (Schulz and de Beer, 2002). However, both methane and sulfide may accumulate as free gas and emerge in small quantities, creating pockmarks (Emeis et al., 2004), or as massive, episodic eruptions, generating a toxic water column (Weeks et al., 2002, 2004; Ohde et al., 2007). Unlike Beggiatoa spp., T. namibiensis is not obligately microaerophilic, and can survive during outgassing events that bring them into contact with oxygenated waters (Schulz and de Beer, 2002). 
(a)

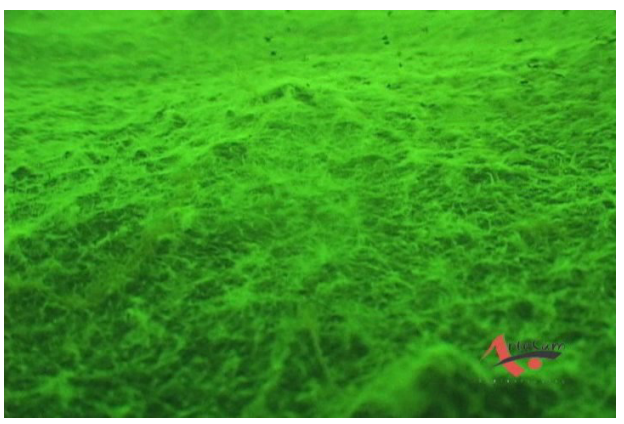

(c)

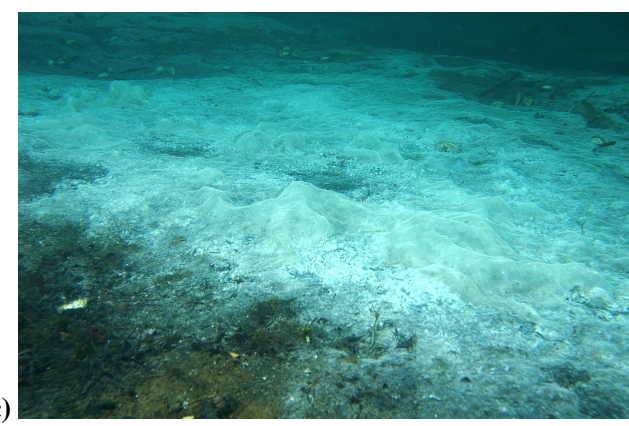

(b)

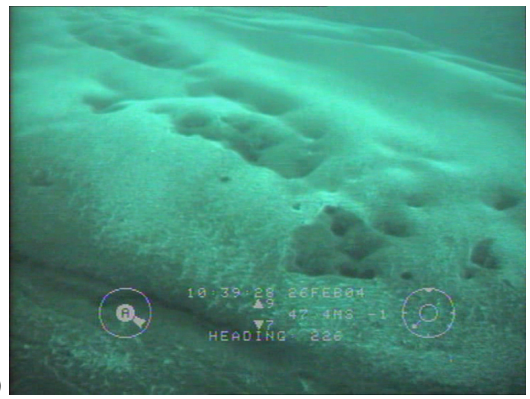

(d)

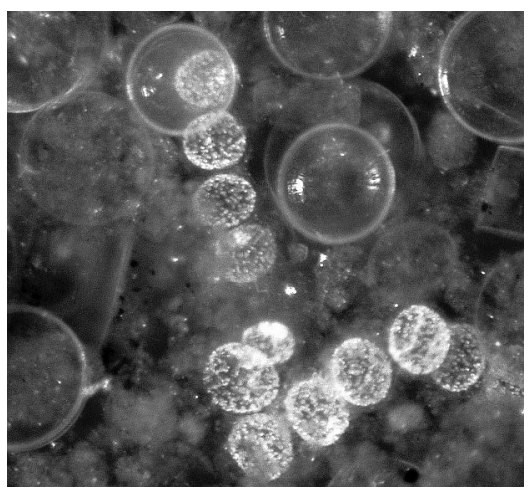

Fig. 4. Bacterial mat formation in coastal waters. (a) Thioploca mat, Concepcion Bay, Chile (10 m), Photograph by Sergio Nuño, (b) Bacterial mat (Beggiatoa and Thiomargarita), Namibia inner shelf $\left(47 \mathrm{~m}, 22^{\circ} 58.7 \mathrm{~S} 14^{\circ} 22.1 \mathrm{E}\right.$, February 2004), Note the pitting from escaped methane gas. Photograph by R. Bahlo (Institut für Ostseeforschung Warnemünde). (c) Beggiatoa mat, New Zealand Fjord (5-10 m) Photograph by S. Wing. (d) Thiomargarita namibiensis against a backdrop of centric diatom frustrules, from the Namibia shelf at $100 \mathrm{~m}$ $\left(19^{\circ} 48.8 \mathrm{~S} 12^{\circ} 46.4 \mathrm{E}\right.$, May 2008).

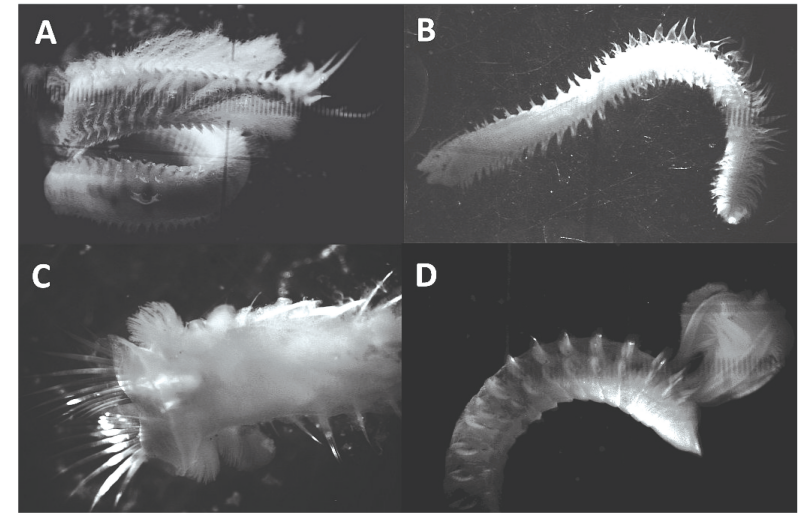

Fig. 5. Elaborate gills and branchiae on polychaetes associated with microbial mats on the Namibian inner shelf. (a) Diopatra sp.; note long spiral branchiae (b) Nereidae; note posterior branchial proliferations (c) Pectinaria sp.; note anterior gill filaments (d) Paraprionospio $\mathrm{sp}$.
Off northern Namibia the OMZ (80-120 m) assemblages are dominated by large aggregations of the molluscs Nassarius vinctus and Nuculana bicuspidata; together these form $73 \%$ of the macrofauna $>1 \mathrm{~mm}$. Species richness is reduced relative to inshore areas (Zettler, 2009). Further south, large areas of the inner shelf are covered by extensive sulfur bacterial mats (Fig. 4b). Here the benthic fauna of the inner shelf ecosystem include spionid, onuphid, pectinarid, hesionid, sigambrid and nereid polychaete species along with nematodes (B. Currie, unpublished data). All have elaborate branchial proliferations (Fig. 5) and most are associated with Beggiatoa and Thiomargarita mats. The bearded goby (Sufflogobius bibarbatus) is the only fish abundant in the matcovered sediments, and shows remarkable capacity to tolerate anoxia (Palm et al., personal communication). The bacteria, especially the Beggiatoa, are capable of removing most of the sulfide using nitrate as an electron acceptor (Schulz and de Beer, 2002; Brüchert et al., 2006). Thus the microbial mats act to detoxify the sediment, permitting the goby to use the benthic habitat as a predator refuge, and providing both the goby and the invertebrates with a low sulfide (but oxygen-depleted) habitat. The gobies migrate to oxygenated waters and feed diurnally (O’Toole, 1978), providing key 
(a)

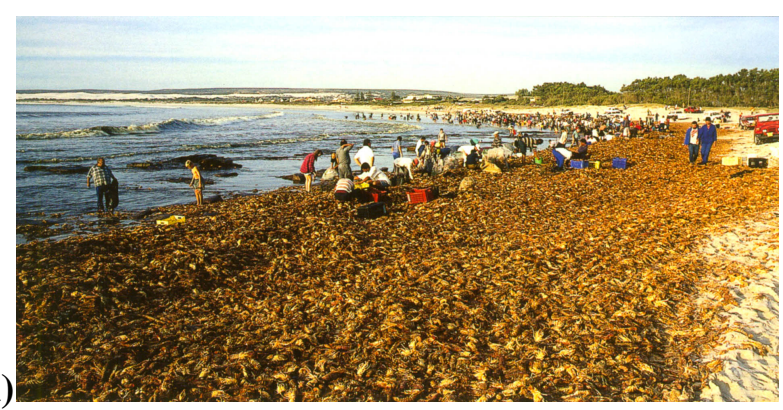

(b)

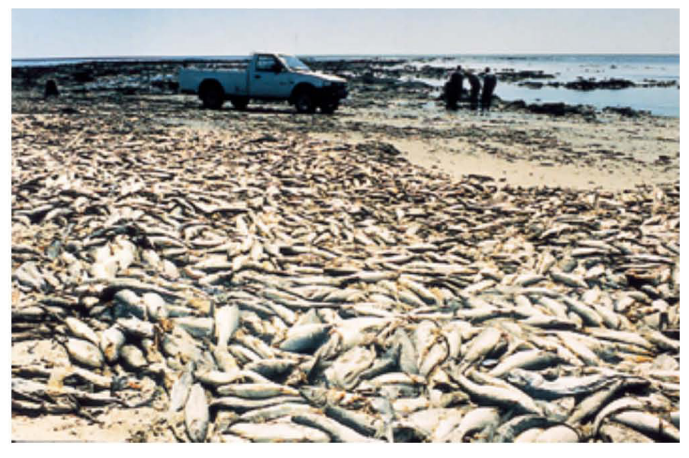

(c)

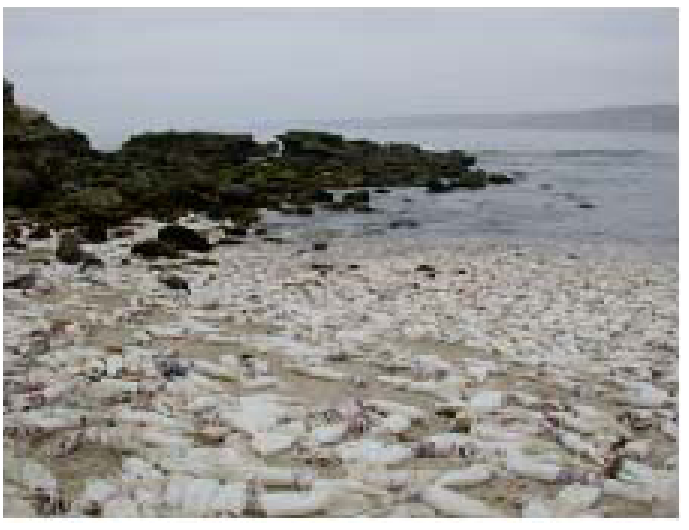

Fig. 6. Mass mortalities. (a) Rock lobster walkout in April 1997 at Elands Bay, South Africa, following water column anoxia induced by decay of a bloom of Ceratium furca. Elands Bay, South Africa. Photo by G. Roland Pitcher (b) Massive fish mortality associated with hydrogen sulfide production following anoxia induced by decay of Ceratium furca and Prorocentrum micans, March 1994, St. Helena Bay, South Africa. Photo by G. Roland Pitcher. (c) Humboldt squid (Dosidicus gigas) swimout on the La Jolla, California shoreline. Photo by Lisa Levin. Similar wash ups have occurred on the Oregon shoreline in 2004 and 2008. The role of hypoxia is uncertain.

food for hake, seabirds and seals in the ecosystem (Crawford and Dyer, 1995; Cury and Shannon, 2004; Palm et al., personal communication).

In general, diversity of intertidal and subtidal benthic algae and invertebrates decreases from the southern to the northern part of the Benguela shelf (Saako, 1998). Pelagic hydrozoans and scyphozoans have recently increased in abun- dance on the Benguela shelf, possibly in response to reduced abundance of clupeid fishes (Bakun and Weeks, 2006) or in response to eutrophication or climate change. In Walvis Bay they prey extensively on bottom organisms and on larvae of benthic invertebrates and thus are considered part of the benthic ecosystem (Flynn and Gibbons, 2007).

Water column sulfur patches on the Namibian coast are detectable by satellite; these may persist between 1-6 days and extend up to $21 \mathrm{~km}$ (Ohde et al., 2007). Seasonal mortality of fishes in Walvis Bay, and the possible involvement of algal blooms, were noted very early by Copenhagen (1953). Algal blooms contribute to oxygen depletion and hasten sulfide and methane eruptions. Mass migrations and/or mortality of cape hake (Merluccius capensis) in response to shifting oxygenation was recorded in the 1990s (Hamakuaya et al., 1998) and up to the present (Fig. 6b) (Monteiro et al., 2008). One of the most dramatic responses of inshore species to hypoxia and sulfide events in the Benguela system involves the activities of rock lobsters (Jasus lalandii). They aggregate inshore (within a mile of shore) where the surf oxygenates the water (Baily et al., 1985) and under extreme conditions will "walk out" (migrate) onto the shore in mass strandings (Fig 6) that lead to extensive mortality over days to a month. Recovery time varies with the area affected and whether hydrogen sulfide was produced (Cockcroft, 2001).

\subsubsection{Pakistan shelf - Arabian Sea}

The Pakistan shelf is subject to seasonal, monsoon-driven hypoxia. An order of magnitude drop in oxygen (from 2.12 to $0.11 \mathrm{ml} \mathrm{L}^{-1}$ ) was observed on the outer Pakistan shelf $(140 \mathrm{~m})$ between pre-monsoon and late southwest monsoon periods in 2003, reflecting an upward shoaling of the OMZ. This was accompanied by a $4.1^{\circ} \mathrm{C}$ drop in temperature and a 0.4 reduction in salinity, due to either a shoaling of the thermocline or possibly contributions from a northward extension of the West India Undercurrent (Brand and Griffiths, 2009). A low-diversity foraminiferal assemblage ( $>300-\mu \mathrm{m}$ fraction) is present at this site, consisting mainly of calcareous species $(60 \%)$ that are largely restricted to the upper $1 \mathrm{~cm}$. Foraminiferal densities increased at this shelf site and in the OMZ core at $300 \mathrm{~m}\left(0.09 \mathrm{ml} \mathrm{L}^{-1}\right)$ following the 2003 southwest monsoon, largely as a result of population increases in the phytodetritus-consuming Uvigerina ex. gr. semiornata (Larkin and Gooday, 2009). The macrofaunal community structure at $140 \mathrm{~m}$ exhibited little response to the southwest monsoon and concomitant oxygen decline. No significant changes in biomass, individual body size, number of polychaete families (21 vs. 25), H', J' and Rank 1 dominance were observed (Hughes et al., 2009). However, lower oxygenation was associated with a reduction in macrofaunal density, burrow counts, and number of polychaete species, with spionid and flabelligerid polychaete densities decreasing. Cirratulid polychaetes remained dominant (about 20\% of the total polychaetes) (Hughes et al., 2009). Macrofauna 
are extremely rare at $300 \mathrm{~m}$ where oxygen remains low and laminations persist (Hughes et al., 2009). Isotope enrichment studies tracking the fate of ${ }^{13} \mathrm{C}$-labeled phytodetritus at $140 \mathrm{~m}$ demonstrated a strong shift in $\mathrm{C}$ processing pathways, with macrofauna responsible for most of the non-bacterial ${ }^{13} \mathrm{C}$ consumption during oxygenated conditions and protozoans (Foraminifera) responsible at $0.11 \mathrm{~mL} \mathrm{~L}^{-1}$ (Woulds et al., 2007, 2009). Additional tracer experiments show corresponding differences in metazoan vs protozoan $\mathrm{C}$ consumption in comparison with the better oxygenated $(940 \mathrm{~m}$; $\left.0.2 \mathrm{ml} \mathrm{L}^{-1}\right)$ and poorly oxygenated $\left(300 \mathrm{~m} ; 0.09 \mathrm{ml} \mathrm{L}^{-1}\right.$ ) sites on the Pakistan margin, suggesting oxygen thresholds influence C cycling pathways (Woulds et al., 2007, 2009).

\subsubsection{West Indian Shelf - Arabian Sea}

The outer Indian shelf and slope are affected by the flow of the West India Undercurrent that is slightly better oxygenated than the waters it mixes with, thus preventing bottom waters over the outer shelf and slope from turning anoxic at least to the south of Goa $\left(15^{\circ} \mathrm{N}\right)$. Nevertheless, the OMZ is still quite well-developed in the region throughout the year (Naqvi et al., 2006). Mazumder et al. (2003) observed high abundance of benthic Foraminifera belonging to the genera Bolivina, Cassidulina, Lernella, Uvigerina and Eponides in surface sediments exposed to the OMZ (depth 150-1500 m) off Goa. Interestingly, Bulimina marginata, which is abundant in other OMZs, accounted for only about $2 \%$ of the total benthic foraminiferal population in this region; instead, Bulimina costata constituted more than $15 \%$ of the total Foraminifera. Nigam et al. (2007) observed high abundance ( $>40 \%$ of benthic Foraminifera) of rectilinear benthic Foraminifera (RBF; e.g., Bolivina, Brizalina, Uvigerina) within the 90-1200 m depth range in the same region, and proposed that the increased abundance of RBF may be used as an indicator of oxygen-depleted conditions in the Arabian Sea.

Hypoxia (and anoxia) on the West India inner shelf exhibits pronounced seasonality due to upwelling associated with southward movement of the West India coastal current during the southwest monsoon. From July to November subsurface oxygen concentrations over the inner and midshelf regions are $<10 \mu \mathrm{M}\left(<0.23 \mathrm{ml} \mathrm{L}^{-1}\right)$. Upwelling of nutrient-rich subsurface waters fertilizes the euphotic zone, increasing oxygen demand while a lens of low-salinity water (from rainfall) maintains stratification and reduces ventilation. Sustained observations off Goa show that denitrification becomes the dominant metabolic pathway in midsummer (July-August) resulting in a removal of $\mathrm{NO}_{3}^{-}$and the accumulation of intermediates $\mathrm{NO}_{2}^{-}$and $\mathrm{N}_{2} \mathrm{O}$, followed by sulfate reduction sometime in September, as evident from the buildup of $\mathrm{H}_{2} \mathrm{~S}$ and $\mathrm{NH}_{4}^{+}$in the bottom waters (Naqvi et al., 2006). The intensity and duration of anoxia varies annually. The oxygen-deficiency is most intense along the central west coast (the Konkan coast) that receives maximal SW monsoon precipitation, and it is less intense south of about $12^{\circ} \mathrm{N}$ (the Malabar coast). The latter region, however, experiences massive dinoflagellate or coccolithophorid blooms during the SW monsoon (Naqvi et al., 1998; Ramaiah et al., 2005). Upwelled water reaches the surface along the Malabar coast more often than it does along the Konkan coast because of a more important role of local wind forcing, resulting in greater eutrophic zone nutrient enrichment and better subsurface ventilation. There is evidence that the extent of hypoxia has increased over the last 40 years and that $\mathrm{H}_{2} \mathrm{~S}$ production is most likely a recent phenomenon. This change corresponds to a 46-fold increase in $\mathrm{N}$ use by South Asian countries as synthetic fertilizer over the same time period (Naqvi et al., 2006).

Few quantitative data document benthic responses to hypoxia on the inner Indian shelf, although the paucity of organisms was noted as early as 1959 by Carruthers et al. (1959) off Bombay. Surface sediments off Goa show the presence of numerous shells but not live bivalves (B. Ingole, unpublished data) supporting an intensification of oxygen deficiency in the recent past. No dense mats of sulfur bacteria, as occur off Chile or Namibia, have been noted on the inner west Indian Shelf, possibly due to lack of free sulfide. Measured sulphate reduction rates are anomalously low in the inner-shelf sediments (Naqvi, unpublished). Thioploca are present elsewhere in the Arabian Sea at deeper depths (Levin et al., 1997; Schmalljohan et al., 2001).

An experimental study by Panchang et al. (2006) involved incubating sediment cores, collected from the midshelf (depth $50 \mathrm{~m}$ ) in the Konkan region, under near in situ temperature-salinity conditions but with varying overlyingwater oxygen levels (fully oxygenated to almost completely oxygen depleted). The experiments revealed that changes in overlying-water oxygen levels (from an initial concentration of $68 \mu \mathrm{M} \approx 1.54 \mathrm{ml} \mathrm{L}^{-1}$ ) invariably resulted in a decrease in foraminiferal counts. In the natural environment, living Foraminifera were confined to the upper $5 \mathrm{~cm}$ of sediments with the most common genera in order of decreasing abundance being Fursenkoina, Nonion, Rotalia and Reophax, with Bulimina, Cancris, Ammotium and Globobulimina also present in smaller numbers. Fursenkoina and Nonion were found to be more tolerant of changes in oxygen than bolivinids and rotaliids. Experimental results implied strong seasonality in the vertical distribution, species composition and counts of Foraminifera (Panchang et al., 2006)

In addition to the afore-mentioned peak in RBF in the outer shelf-slope region that is exposed to the open ocean OMZ, Nigam et al. (2007) documented a secondary peak in RBF at 50-60 m off Goa, where they form over $78 \%$ of the benthic Foraminifera. This Bolivina-Bulimina-dominated assemblage is indicative of organic enrichment, as a similar assemblage occurs in sediments overlain by oxygenated waters on the Florida continental shelf (Sen Gupta et al., 1981). The macrobenthos in the same region show elevated dominance and reduced species richness at this depth (Jayaraj et al., 
2007) although oxygen levels were high during winter sampling. Macrobenthic densities were unusually low at $30 \mathrm{~m}$, which falls within the zone of seasonal sulphate reduction (Naqvi et al., 2006). Among polychaetes, three species in the spionid genus Prionospio, cirratulids (Cirriformia afer), Cossura coasta and Sternaspis scutata are abundant on the inner shelf $(<50 \mathrm{~m})$. These deposit feeders are replaced by more carnivorous species including Lepidonotus carinulatus, Ancistrosyllis constricta, and Syllis spongicola, as well as by Amphicteis gunneri, Notomastus aberrans and Cirratulis cirratus on the outer shelf $(>100 \mathrm{~m})$. Dissolved oxygen was found to be a contributing but not overriding factor controlling assemblage structure (Jayaraj et al., 2007). Many of the inshore regions exhibit poor water quality due to extensive domestic and industrial waste disposal; very low dissolved oxygen occurs post monsoon in fall, which is mainly due to anoxia developing along the open coast. Prionospio pinnata is dominant in these open coastal areas when oxygen declines to $2 \mathrm{ml} \mathrm{L}^{-1}$ or lower (Varshney et al., 1988).

Demersal fish and shellfish species disappear seasonally from the outer shelf off Cochin (along the Malabar coast), and often aggregate in estuarine waters along the west coast. Solar prawns (Metapenaeus dobsoni) are caught in large quantities during such events. Critical oxygen levels for the dominant fish Synagris japonicus, expected to be most tolerant to hypoxia, are $0.25-0.50 \mathrm{ml} \mathrm{L}^{-1}$ (Banse, 1959)

Inner- and mid-shelf hypoxia is distinct from the deeper offshore suboxic zone, in part due to the presence of the above-mentioned better oxygenated West India Undercurrent, which flows along the continental margin between the two systems. Sometimes during anoxic inner shelf events, fish appear to aggregate on the outer shelf, as intense trawling is observed. At other times fish kills occur when escape from anoxic waters is not possible. The demersal fish catch along the west coast has undergone large fluctuations over the past decade, apparently related to changes in bottom-water oxygen and $\mathrm{H}_{2} \mathrm{~S}$ levels. The conditions were most severe in 2001, when the temperature of the upwelled water was lowest, and the prawn fishery nearly collapsed. The landing in Goa, for example, fell by a factor of ten, as $\mathrm{H}_{2} \mathrm{~S}$ was present at depths up to $65 \mathrm{~m}$ (Naqvi et al., 2009). However, a recovery to the "normal" level has since occurred (especially after 2005). Although $\mathrm{H}_{2} \mathrm{~S}$ is still present, the duration of complete anoxia is shorter than in the early 2000s.

\subsubsection{East India shelf - Bay of Bengal}

The East Indian shelf in the Bay of Bengal is not subject to hypoxia at very shallow depths as happens in the Arabian Sea, despite intense river runoff. Weaker upwelling and limited DIN loading are believed to be responsible (Naqvi et al., 2006). Despite the consequently lower primary productivity of the Bay of Bengal, the biomass and population density of benthic organisms over the eastern and western shelves of India are similar, although most of the data were gener- ated before the intensification of hypoxia over the western shelf (Ansari et al., 1977; Ansari et al., 1982; Parulekar et al., 1982). The density of infauna is especially high close to river mouths [meiofauna: $226-96710 \mathrm{~cm}^{-2}$; macrofauna: 90-4785 $\mathrm{m}^{-2}$; Ansari et al., 1982]. Among the various taxonomic groups of macrobenthos, polychaetes, bivalves and crustaceans were the most abundant. The meiobenthos is dominated by Foraminifera and nematodes followed by polychaetes and ostracods (Ansari et al., 1977, 1982; Parulekar et al., 1982).

Below the surface mixed layer (which is deeper over the eastern Indian shelf), as in other parts of the North Indian Ocean, oxygen declines sharply from saturated values to concentrations between $\sim 0$ and $0.5 \mathrm{ml} \mathrm{L}^{-1}$ at depths of 150 $200 \mathrm{~m}$. Recent investigations on the shelf between $16^{\circ}$ and $20^{\circ} \mathrm{N}$ reveal steep drops in macrofaunal diversity $\left(\mathrm{H}^{\prime}\right)$ and evenness $\left(\mathrm{J}^{\prime}\right)$ and a rise in dominance $(>90 \%)$, mirroring oxygen declines across the shelf. These also parallel a rise in sediment organic matter content up to $6 \%$ TOC on the outer shelf. At oxygen concentrations below $0.10 \mathrm{ml} \mathrm{L}^{-1}$, the polychaetes Prionospio sp. and Cossura coasta, and nemerteans comprise most of the macrobenthos (Raman and Rao, unpublished data).

\section{Synthesis: general benthos responses to hypoxia}

The sections below summarize general hypoxia responses of different benthic size or taxonomic groups. Table 1 provides an overview of the characteristic genera and species common to hypoxic regions around the world and Table 2 summarizes the community-level responses across major size groups. We attempt to assess whether the cause of hypoxia (human vs natural) affects these responses, but caution that often interactions between the two types of forcing as well as sitespecific environmental differences prevent a clear assessment of this issue.

\subsection{Mat-forming microbes}

Microbial responses to hypoxia are intimately tied to geochemistry, in both sediments and the water column. Although this review does not treat these interactions (see Middelburg and Levin, 2009), we consider mat-forming microbes to be a fundamental macroscopic feature of benthic ecosystems subject to severe hypoxia. These mats are formed largely of filamentous sulfide oxidizing bacteria in the genera Beggiatoa, Thioploca, or Thiomargarita, although sulfate reducing and methane oxidizing bacteria are often intermixed (Graco et al., 2004; Ding and Valentine, 2008). Primary differences among the dominant genera involve the presence of a sheath and multiple filaments (Thioploca) or bead-like construction (Thiomargarita), and their ability to function in the presence or absence of oxygen (Jørgensen and Gallardo, 1999; Brüchert et al., 2003, 2006). All are capable 
Table 1. Characteristic fauna of hypoxic coastal settings. See text discussions for citations.

\begin{tabular}{|c|c|c|c|c|c|c|c|c|c|}
\hline Location & $\begin{array}{l}\text { Mat-Forming Mi- } \\
\text { crobes }\end{array}$ & Foraminifera & Polychaetes & Molluses & Crustaceans & $\begin{array}{l}\text { Other } \\
\text { Invertebrates }\end{array}$ & Fishes & Notable Phenomena & $\begin{array}{l}\text { Exacerbating Fac- } \\
\text { tors }\end{array}$ \\
\hline \multicolumn{10}{|l|}{ Seasonal } \\
\hline Louisiana Shelf & Beggiatoa & $\begin{array}{l}\text { Pseudononion atlanticum, } \\
\text { Epistominella vitrea, Bu- } \\
\text { liminella morgani (mid } \\
\text { shelf); Ammonia parkinso- } \\
\text { niana (inner shelf) }\end{array}$ & $\begin{array}{l}\text { Amphareter, Magelona } \\
\text { tolerant through hypoxic } \\
\text { months, Paraprionospio } \\
\text { pinnata, Mediomastus } \\
\text { ambiseta, Sigambra tentac- } \\
\text { ulata, at initiation and end } \\
\text { of hypoxia }\end{array}$ & & & \multirow[t]{3}{*}{$\begin{array}{l}\text { Aspidosiphon } \\
\text { sp. (Sipuncula) }\end{array}$} & & $\begin{array}{l}\text { Hypoxia is a summer } \\
\text { phenomenon, areal cover } \\
\text { of hypoxia varies each } \\
\text { summer. Hurricanes re- } \\
\text { duce hypoxic area }\end{array}$ & $\begin{array}{lr}\begin{array}{l}\text { Nutrient } \\
\text { from the }\end{array} \text { Mis- } \\
\text { sissippi } & \text { River } \\
\text { watershed } & \end{array}$ \\
\hline $\begin{array}{l}\text { Chesapeake } \\
\text { Bay }\end{array}$ & & $\begin{array}{l}\text { Ammonia parkinsoniana } \\
\text { (Elphidium selseyensis, } \\
\text { Ammobaculites exiguus } \\
\text { intolerant) }\end{array}$ & $\begin{array}{l}\text { Paraprionospio pinnata, } \\
\text { Polydora ligni, Streblospio } \\
\text { benedicti, Mediomastus } \\
\text { ambiseta, Leitoscoloplos } \\
\text { fragilis, Glycinde soli- } \\
\text { taria, Eteone heteropoda } \\
\text { Asabellides oculata. }\end{array}$ & $\begin{array}{l}\text { Mulinia } \\
\text { lateralis }\end{array}$ & $\begin{array}{l}\text { Ostracod - } \\
\text { Cytheromorpha } \\
\text { curta }\end{array}$ & & $\begin{array}{l}\text { Spot (Leiostomus xan- } \\
\text { thurus), Croaker (Micro- } \\
\text { pogonias undulatus) }\end{array}$ & $\begin{array}{l}\text { Habitat compression of } \\
\text { fishes, prey behavior en- } \\
\text { hances food for fishes, } \\
\text { oyster reef loss with cas- } \\
\text { cading effects on com- } \\
\text { munity and trophic struc- } \\
\text { ture. Loss of biomass, } \\
\text { biodiversity and long- } \\
\text { lived macrofauna }\end{array}$ & $\begin{array}{l}\text { Eutrophication, } \\
\text { overfishing (oys- } \\
\text { ters) }\end{array}$ \\
\hline $\begin{array}{l}\text { Changjiang } \\
\text { Estuary \& Inner } \\
\text { Shelf }\end{array}$ & & & Glycera chirori & $\begin{array}{l}\text { Thyasira } \\
\text { tokunagai }\end{array}$ & $\begin{array}{l}\text { Callianassa } \\
\text { japonica }\end{array}$ & & $\begin{array}{lr}\text { Trichiurus } & \text { lepturus, } \\
\text { Larimichthys polyacti } \\
\text { and Portunus } & \text { tritubercu- } \\
\text { latus }\end{array}$ & $\begin{array}{l}\text { Macro and meiofaunal } \\
\text { density drops in hypoxic } \\
\text { area, aggregations of } \\
\text { megafauna at edges. } \\
\text { Collapses of benthos and } \\
\text { conversion to pelagic } \\
\text { system }\end{array}$ & $\begin{array}{l}\text { Eutrophication, in- } \\
\text { vasions via ballast } \\
\text { water }\end{array}$ \\
\hline $\begin{array}{l}\text { Scandinavian } \\
\text { and Scottish } \\
\text { fjords }\end{array}$ & & $\begin{array}{l}\text { Stainforthia fusiformis, } \\
\text { Spiroplectammina biformis, } \\
\text { Bulimina marginata }\end{array}$ & $\begin{array}{l}\text { Heteromastus filiformis, } \\
\text { Melinna cristata, Spio- } \\
\text { phanes kroyeri, Capitella } \\
\text { capitata, Scalibregma } \\
\text { inflatum (fish farms) }\end{array}$ & $\begin{array}{l}\text { Abra } \\
\text { nitida, } \\
\text { Thyasira equlis. } \\
\text { Thyasira sarsi }\end{array}$ & & $\begin{array}{l}\text { Amphiura } \\
\text { chiajei, A. filiformis } \\
\text { (Ophiuroidea) }\end{array}$ & & $\begin{array}{l}\text { Limited flushing in- } \\
\text { creases influence of } \\
\text { human activities, mus- } \\
\text { sels can exacerbate } \\
\text { hypoxia }\end{array}$ & $\begin{array}{l}\text { pulp mill, aquacul- } \\
\text { ture, sewage inputs }\end{array}$ \\
\hline Chilean Shelf & Thioploca spp. & & $\begin{array}{l}\text { Paraprionospio pinnata, } \\
\text { Mediomastus branchiferus, } \\
\text { Aricidea pigmentata, } \\
\text { Nephtys ferruginea and } \\
\text { Cossura chilensis }\end{array}$ & & & & & $\begin{array}{l}\text { ENSO cycles modify } \\
\text { seasonal patterns. El } \\
\text { Niño improves oxy- } \\
\text { genation, attenuating } \\
\text { seasonality and favoring } \\
\text { larger, deeper-dwelling } \\
\text { taxa }\end{array}$ & La Niña \\
\hline $\begin{array}{l}\text { Peru Shelf, } \\
\text { Ancon Bay } \\
15 \mathrm{~m}\end{array}$ & & & $\begin{array}{l}\text { Owenia collaris, Magelona } \\
\text { phyllisae, Chaetozone sp. } \\
\text { and Phoronis sp. }\end{array}$ & & $\begin{array}{l}\text { Ampelisca } \\
\text { araucana }\end{array}$ & & & & \\
\hline $\begin{array}{l}\text { Pakistan shelf, } \\
140 \mathrm{~m}\end{array}$ & Thioploca spp. & Uvigerina semiornata & $\begin{array}{l}\text { Cirratulidae and Spionidae } \\
\text { dominant }\end{array}$ & & & & & $\begin{array}{l}\text { Seasonal, order of mag- } \\
\text { nitude decline in oxygen } \\
\text { following SW monsoon, } \\
\text { corresponds to density } \\
\text { declines in Spionidae } \\
\text { and Flabelligeridae }\end{array}$ & \\
\hline $\begin{array}{l}\text { W. Indian Inner } \\
\text { Shelf }\end{array}$ & & & $\begin{array}{l}\text { Prionospio, Cirriformia } \\
\text { afer, Cossura coasta, } \\
\text { Sternaspis scutata }\end{array}$ & & $\begin{array}{l}\text { Metapenaeus } \\
\text { dobsoni }\end{array}$ & & Synagris japonicus & $\begin{array}{l}\text { Monsoon driven up- } \\
\text { welling, seasonal sulfide } \\
\text { exposure }\end{array}$ & $\begin{array}{l}\text { Atmospheric nutri- } \\
\text { ent enrichment, do- } \\
\text { mestic and indus- } \\
\text { trial waste disposal }\end{array}$ \\
\hline $\begin{array}{l}\text { W. Indian } \\
\text { Outer shelf }\end{array}$ & & $\begin{array}{l}\text { Rectilinear bi- and tri-serial } \\
\text { taxa (e.g. Bolivina and Bu- } \\
\text { limina, Fursenkoina) }\end{array}$ & $\begin{array}{l}\text { Prionospio pinnata, Lep- } \\
\text { idonotus carinulatus, An- } \\
\text { cistrosyllis constricta, Syl- } \\
\text { lis spongicola, Amphicteis } \\
\text { gunneri, Notomastus aber- } \\
\text { rans and Cirratulis cirratus }\end{array}$ & & & & & & \\
\hline $\begin{array}{l}\text { Benguela } \\
\text { Outer Shelf }\end{array}$ & & & & & & & $\begin{array}{l}\text { Merluccius } \\
\text { paradoxus, } \text { M. capensis }\end{array}$ & $\begin{array}{l}\text { Benguela Niños can } \\
\text { move the system from } \\
\text { seasonal to persistent } \\
\text { hypoxia }\end{array}$ & $\begin{array}{l}\text { Ocean warm- } \\
\text { ing trends may } \\
\text { be intensifying } \\
\text { seasonality }\end{array}$ \\
\hline Japanese Bays & & $\begin{array}{lr}\text { Ammonia } & \text { beccarii, } \\
\text { Trochammina hadai, } \\
\text { Eggerella advena, Uviger- } \\
\text { inella glabra. Also Virgu- } \\
\text { linella fragilis in sulphidic } \\
\text { habitat (Namako-ike, } \\
\text { Japan) }\end{array}$ & & & $\begin{array}{l}\text { Ostracods- } \\
\text { Bicornucythere } \\
\text { bisanensis, } \\
\text { B. sp., Cytheromor- } \\
\text { pha acupunctata, } \\
\text { Loxooconcha viva }\end{array}$ & & & & \\
\hline \multicolumn{10}{|l|}{ Permanent } \\
\hline Black Sea & & $\begin{array}{ll}\text { Ammonia, } & \text { Monotha- } \\
\text { lamous taxa } & \text { including } \\
\text { Psammophaga } & \end{array}$ & $\begin{array}{l}\text { Protodrilus sp. and Vic- } \\
\text { torniella zaikai }\end{array}$ & $\begin{array}{l}\text { Mytilus gallo- } \\
\text { provincialis }\end{array}$ & & & & $\begin{array}{l}\text { Mussels keep phyto- } \\
\text { plankton blooms in } \\
\text { check. Loss of mussels } \\
\text { led to cascade, shift to } \\
\text { domination by comb } \\
\text { jellies Mnemiopsis leydi }\end{array}$ & $\begin{array}{l}\text { Overfishing, } \\
\text { species invasion }\end{array}$ \\
\hline Baltic Sea & & & $\begin{array}{lrr}\text { Scoloplos } & \text { armiger, } \\
\text { Capitella } & \text { sp., } & \text { Pygospio } \\
\text { elegans } & & \end{array}$ & Macoma baltica & 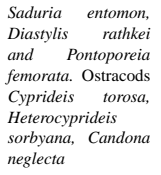 & $\begin{array}{l}\text { Halicryptus spinulo- } \\
\text { sus(Priapula) }\end{array}$ & & & Eutrophication \\
\hline $\begin{array}{l}\text { Peru, Ancon } \\
\text { Bay ( } 34 \mathrm{~m} \text { and } \\
\text { below) }\end{array}$ & & & $\begin{array}{l}\text { Paraprionospio pinnata, } M . \\
\text { phyllisae, Chaetozone sp. } \\
\text { and Leitoscoloplos chilen- } \\
\text { sis }\end{array}$ & & & & & $\begin{array}{l}\text { El Niño improves oxy- } \\
\text { genation and leads to } \\
\text { colonization by scallops, } \\
\text { octopus and whelks }\end{array}$ & \\
\hline $\begin{array}{l}\text { Benguela Inner } \\
\text { Shelf }\end{array}$ & $\begin{array}{l}\text { Beggiatoa, } \\
\text { Thiomargarita } \\
\text { namibiensis, } \\
\text { Thioploca }\end{array}$ & $\begin{array}{l}\text { Virgulinella fragilis occurs } \\
\text { in Walvis Bay, Namibia. } \\
\text { Characteristic species for } \\
\text { sulphidic environments } \\
\text { (Tsuchiya et al., 2008) }\end{array}$ & $\begin{array}{l}\text { Diopatra sp., Paraprionos- } \\
\text { pio sp. Nephtys sp., Sygam- } \\
\text { bra sp., Pectinaria sp., Hes- } \\
\text { ionidae }\end{array}$ & $\begin{array}{l}\text { Nassarius vinc- } \\
\text { tus } \\
\text { Nuculana bicus- } \\
\text { pidata }\end{array}$ & $\begin{array}{l}\text { Bathynecties } \\
\text { piperitus }\end{array}$ & & $\begin{array}{l}\text { Sufflogobius } \\
\text { bibarbatus }\end{array}$ & $\begin{array}{l}\text { Eruptions of hydrogen } \\
\text { sulfides create anoxic } \\
\text { water columns and gas } \\
\text { release visible from } \\
\text { satellites. Microbial } \\
\text { mats are capable of } \\
\text { consuming much of the } \\
\text { slow sulfide flux }\end{array}$ & $\begin{array}{l}\text { Algal blooms oc- } \\
\text { cur coincident with } \\
\text { hypoxia. Lobster } \\
\text { 'walkouts' gener- } \\
\text { ate mass mortality } \\
\text { of a key fisheries } \\
\text { species }\end{array}$ \\
\hline
\end{tabular}


Table 2. Summary of benthic community responses to severe coastal hypoxia.

\begin{tabular}{|c|c|c|c|c|c|c|}
\hline Attribute & Microbial Mat & Foraminifera & $\begin{array}{l}\text { Metazoan } \\
\text { Meiofauna }\end{array}$ & Macroinfauna & $\begin{array}{l}\text { Megafaunal } \\
\text { Invertebrates }\end{array}$ & $\begin{array}{l}\text { Demersal Fish } \\
\text { and Shellfish }\end{array}$ \\
\hline Abundance & High & High & High & Reduced & Reduced & Reduced \\
\hline Biomass & High & Reduced & Reduced & Reduced & Reduced & Reduced \\
\hline Body Size & Large & $\begin{array}{l}\text { Small, thin } \\
\text { walled }\end{array}$ & $\begin{array}{l}\text { Small, some } \\
\text { large in the } \\
\text { OMZ }\end{array}$ & Reduced & & Reduced \\
\hline $\begin{array}{l}\text { Dominant } \\
\text { (Hypoxia- } \\
\text { tolerant) Taxa }\end{array}$ & $\begin{array}{l}\text { Beggiatoa, } \\
\text { Thioploca }\end{array}$ & $\begin{array}{l}\text { Hyaline, } \\
\text { calcareous } \\
\text { forms }\end{array}$ & Nematodes & $\begin{array}{l}\text { Annelids } \\
\text { (Spionidae, } \\
\text { Capitellidae, } \\
\text { Magelonidae), } \\
\text { Sipunculans, } \\
\text { Priapula }\end{array}$ & $\begin{array}{l}\text { Cnidarians, } \\
\text { Ophiuroids } \\
(\mathrm{OMZ})\end{array}$ & $\begin{array}{l}\text { Gobies (Namibia), } \\
\text { hogchoker } \\
\text { (Chesapeake Bay) }\end{array}$ \\
\hline $\begin{array}{l}\text { Species } \\
\text { Richness }\end{array}$ & & Reduced & Reduced & Reduced & Reduced & \\
\hline Evenness & & Reduced & Reduced & Reduced & Reduced & \\
\hline Dominance & & High & High & High & $\begin{array}{l}\text { Mostly } \\
\text { intolerant }\end{array}$ & $\begin{array}{l}\text { Mostly } \\
\text { intolerant }\end{array}$ \\
\hline Behavior & $\begin{array}{l}\text { aggregate at } \\
\text { sediment } \\
\text { surface }\end{array}$ & $\begin{array}{l}\text { Shallow } \\
\text { dwelling in } \\
\text { sediments }\end{array}$ & $\begin{array}{l}\text { Migrate upward } \\
\text { within } \\
\text { sediments }\end{array}$ & $\begin{array}{l}\text { Migrate to } \\
\text { surface, } \\
\text { reduced } \\
\text { dwelling } \\
\text { depths, suface } \\
\text { feeding }\end{array}$ & $\begin{array}{l}\text { Move away, } \\
\text { emerge from } \\
\text { sediments, } \\
\text { Evisceration, } \\
\text { depart from } \\
\text { shell }\end{array}$ & $\begin{array}{l}\text { Swim } \\
\text { away/Avoidance, } \\
\text { Impaired } \\
\text { reproduction }\end{array}$ \\
\hline $\begin{array}{l}\text { Functional } \\
\text { effects }\end{array}$ & $\begin{array}{l}\text { Sulfide } \\
\text { removal, } \\
\text { dominate C } \\
\text { flow }\end{array}$ & $\begin{array}{l}\text { Dominate C } \\
\text { cycling }\end{array}$ & $\begin{array}{l}\text { Reduced micro- } \\
\text { scale } \\
\text { bioturbation, C } \\
\text { processing }\end{array}$ & $\begin{array}{l}\text { Reduced } \\
\text { bioturbation, C } \\
\text { processing }\end{array}$ & & \\
\hline $\begin{array}{l}\text { Recovery } \\
\text { following } \\
\text { hypoxia }\end{array}$ & Disappear & Rapid & Rapid & Mixed & Slower & Mixed \\
\hline
\end{tabular}

of using nitrate as an electron acceptor. Biomass of these mega-bacteria can be unusually high; Thioploca reaches $120 \mathrm{~g}_{\text {wet }} \mathrm{wt} \mathrm{m}^{-2}$ (Gallardo, 1977) and Thiomargarita nami-

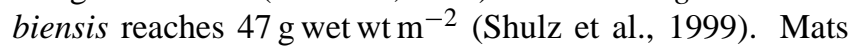
of Thioploca form permanently on the Peru shelf and seasonally off central Chile, as well as on the upper slope of Oman and Pakistan (Jørgensen and Gallardo, 1999) and off Namibia (Gallardo et al., 1998). However, Beggiatoa and Thiomargarita are the primary mat-forming taxa on the inner Namibian shelf (Schulz et al., 1999; Brüchert et al., 2003, 2006).

Thioploca mats appear to be more commonly characteristic of naturally occurring hypoxic systems associated with upwelling and high nitrate concentrations. In contrast, microbial mats caused by mass degradation of macroalgal or phytoplankton blooms in eutrophic settings (e.g. Graco et al., 2001; Glud et al., 2004) or of animals that have died in response to hypoxia in estuarine, inner shelf, and basin settings are most often formed by Beggiatoa and Thiothrix. Recently another diverse group of filamentous "macro" bacteria have been described from sulfidic shelf sediments in the eastern
Pacific Ocean off Chile, Peru, Panama and Costa Rica. They appear to be sulfide oxidizers and can be associated with sheaths of Thioploca, but are an order of magnitude smaller, (i.e. $10 \mathrm{~s}$ instead of $100 \mathrm{~s}$ of microns in length) (Gallardo and Espinoza, 2007).

Many protozoans and metazoan animals live in association with mats of mega- and macro-bacteria, including some eukaryotes with symbiotic bacteria (Bernhard et al., 2000; Gallardo and Espinoza, 2007). An active hypothesis is that large mat-forming, sulfide- oxidizing bacteria detoxify sediment by removing sulfide, and thus facilitate metazoan habitation. In this regard, a positive correlation between Thioploca and meiofaunal biomass was observed on the central Chile shelf during non-El Niño conditions when Thioploca was abundant; after El Niño, when Thioploca declined, no relationship was found. Although this evidence does not verify a detoxification role for Thioploca mats, Thioploca presence is thought to have had a positive influence on meiofauna (Neira et al., 2001b). The different bacterial taxa exhibit differences in their sulfide removal capacity (Brüchert et al., 2006), but the extent to which 
these differences control animal distributions, and whether they are related to the source of hypoxic conditions, requires further study.

\subsection{Plants and algae}

The response of benthic primary producers (seagrasses, macroalgae and microalgae) to eutrophication has been studied extensively (e.g. Duarte, 1995; Valiela et al., 1997). The current conceptual model involves a shift in dominance from seagrasses and perennial macroalgae to initially ephemeral bloom-forming macroalgae and epiphytes and ultimately to phytoplankton dominance. Eutrophication and hypoxia cause large benthic macrophytes with high biomass, high light requirements and low nutrient turnover to be replaced by small pelagic algae with lower light requirement, low biomass and high turnover (Duarte, 1995; McGlathery et al., 2007). This shift from benthic to pelagic primary producers has been attributed primarily to competition for light. Increasing nutrients stimulate phytoplankton with the consequence that underlying vegetation is shaded. Although the response of microphytobenthos (benthic microalgae and cyanobacteria) to nutrient addition has been studied extensively, there are few data on their response to eutrophication at an ecosystem scale. One would expect a decrease in microphytobenthos importance as a system becomes eutrophied because of shading by phytoplankton (Vadeboncoeur et al., 2003). However, benthic microalgae are adapted to photosynthesize in very low light levels, as low as 5$10 \mu \mathrm{E} \mathrm{m}^{-2} \mathrm{~s}^{-1}$ and $1 \%$ surface incident radiation (Sundbäck and Graneli, 1988; Cahoon et al., 1994). Their numbers are high below phytoplankton-shaded waters on the Louisiana continental shelf (Baustian, unpublished data).

The effect of hypoxic and anoxic waters on seagrasses has been studied extensively (Burkholder et al., 2007). Hypoxia impedes respiration and many metabolic functions including nutrient uptake by seagrasses (Smith et al., 1988). Although short-lived extreme events may result in seagrass shoot dieoff, colonization by surviving seedlings may provide some resilience (Plus et al., 2003). The consequences of consecutive short-term hypoxic events need to be investigated. Bottom-water hypoxia, high organic carbon loading and lack of sediment reactive iron alone or in combination (Middelburg and Levin, 2009) may cause high concentrations of sulfide in sediments with adverse effects on seagrass functioning and survival (Burkholder et al., 2007).

Larson and Sundbäck (2008) experimentally investigated the effect of short-lived hypoxic events on microphytobenthos. They found that benthic microalgae can show high resilience after hypoxic events (i.e. high rates of recovery) and suggested that the recovery time is related to the duration of the hypoxic event. Montserrat et al. (2008) defaunated intertidal estuarine sediments by covering them with polyethylene sheets for 40 days causing anoxia in the sediments. Following removal of the sheets, microphytobenthos recovered rapidly and showed extensive growth of cyanobacteria and diatoms. Extensive mats of microphytobenthos developed in one month, partly or perhaps mainly due to the absence of grazers. This high resilience of microphytobenthos has been attributed to the capability of these organisms to enter dormant stages, thereby minimizing respiration losses (Larson and Sundbäck, 2008).

\subsection{Foraminifera}

The interest of palaeoceanographers in developing proxies for palaeo-oxygenation and productivity, together with studies of oxygen minimum zones and hypoxic basins, have generated a substantial body of data on Foraminifera in naturally hypoxic systems (Sen Gupta and Machain-Castillo, 1993; Bernhard and Sen Gupta, 1999; Gooday et al., 2009). A fundamental problem in these studies has been to distinguish the effects of organic enrichment from those of oxygen depletion. Many of the changes in foraminiferal community structure and composition seen in hypoxic environments are likely to reflect changes in the quantity and quality of the organic matter supplies to the sea floor. Species that are less resistant to a shortage of oxygen begin to disappear only when oxygen concentrations fall below a critical level, possibly $\sim 0.5 \mathrm{ml} \mathrm{L}^{-1}$ or less, leading to reduced species richness and a change in species composition (Gooday, 2003; Jorissen et al., 2007). Some species are able to tolerate prolonged anoxia. Short-term tolerance of sulphide is also reported, based on experimental studies in which rose Bengal staining was supported by live observations (Moodley et al., 1998).

Foraminifera possess a number of ultrastructural and biochemical features which may help them to survive in extreme hypoxic/sulphidic environments (Bernhard and Sen Gupta, 1999). These include the presence of bacterial symbionts (Bernhard, 2003) and sequestered chloroplasts (Bernhard and Bowser, 1999), as well as peroxisomes that facilitate the respiration of oxygen derived from the breakdown of hydrogen peroxide (Bernhard and Bowser, 2008). In addition, at least some hypoxia-tolerant species are able to respire nitrate (Risgaard-Petersen et al., 2006). It should be remembered that the majority of Foraminifera live some distance below the sediment/water interface. Unlike most macro- and megafaunal organisms, which are in contact with bottom water, Foraminifera are surrounded by sediment pore water. As a result, species that live deeper in the sediment are exposed to hypoxic and anoxic micro-environments, even when the overlying bottom water is well oxygenated.

Reviews of Foraminifera in oxygen-depleted habitats are provided by Sen Gupta and Machain-Castillo (1993), Jorissen (1999), Bernhard and Sen Gupta (1999), Gooday (2003), Murray (2006), Jorissen et al. (2007), and Gooday et al. (2009). Assemblages typically exhibit a number of characteristics, which can be summarised as follows.

(1) As a group, Foraminifera are more tolerant of hypoxia than most metazoans. Their standing stocks are often 
very high, probably reflecting a rich food supply combined with a scarcity of competitors and predators in these habitats (Phleger and Soutar, 1973; Phleger, 1976). In hypoxic areas where they are the most abundant eukaryotic organisms, Foraminifera dominate carbon uptake and cycling (Woulds et al., 2007, 2009).

(2) Although most Foraminifera tolerate fairly low oxygen concentrations, a relatively small number of genera and species dominate the assemblages in strongly hypoxic conditions. Elongate, sometimes flattened, biserial or triserial morphotypes (RBF, e.g. Brizalina, Bolivina) are often common, but a variety of spiral and other test shapes (e.g. Cassidulina, Epistominella) are also found (Bernhard and Sen Gupta, 1999; Jorissen et al., 2007). However, few Foraminiferal taxa or morphotypes are restricted to hypoxic environments (Sen Gupta and Machain-Castillo, 1993; Murray, 2001, 2006). An exception may be Virgulinella fragilis, which appears to be a sulfide specialist (Tsuchiya et al., 2008).

(3) Fauna of hypoxic settings are usually dominated by taxa with hyaline, calcareous tests (rotaliids, buliminids). In many cases, the tests are small and thin-walled. Agglutinated and organic-walled taxa are less common, although they are by no means absent (Gooday et al., 2000; Bernhard et al., 2006).

(4) In hypoxic environments, Foraminifera typically live close to the sediment-water interface. This applies even to taxa that live deeper in the sediment in well-ventilated settings, presumably because deeper layers have become too inhospitable. Some of the most tolerant species are considered to be deep infaunal species because they occupy microhabitats well below the sediment/water interface in sediments overlain by oxic seawater. However, in some areas, hypoxic assemblages are dominated by species with planispiral test morphologies, typical of niches close to the sediment surface. These taxa, which appear to be especially adapted to hypoxia at the sediment-water interface, are rare in well-oxygenated settings (Jorissen et al., 2007).

(5) The elimination of hypoxia-sensitive foraminiferal species leads to a reduction in species richness, while the abundance of a few hypoxia-tolerant species results in increased dominance. As a result, indices of species diversity that combine richness and dominance are depressed compared to more oxic environments (Gooday et al., 2000).

Much of our information about hypoxia-tolerant Foraminifera comes from bathyal settings where hypoxia occurs naturally, principally oxygen minimum zones, silled continental margin basins and fjords, and methane seeps (Bernhard and Sen Gupta, 1999). In most of these areas, hypoxic conditions have persisted for thousands and millions of years. Studies in shallower water have focused mainly on areas off major rivers, such as the North Adriatic (River Po) and the northern Gulf of Mexico (Mississippi River), where hypoxia is exacerbated by human influences (Van der Zwaan and Jorissen, 1991).
Since hypoxic conditions are mostly seasonal in coastal systems, the severity of oxygen depletion varies on a yearly and seasonal scale. In many cases, strong hypoxia persist for only short periods of time, which may be too short to cause the disappearance of the more sensitive species. It is therefore probable that the specific faunas of these areas are mainly a reflection of the strongly increased organic input, often with a large proportion of terrestrial components. An exception can be noted for the genus Quinqueloculina, which is hypoxia-intolerant and has disappeared from the foraminiferal community on the Louisiana continental shelf (Rabalais et al., 1996).

The species inhabiting these coastal and sublittoral areas are different from those found at bathyal depths; for example, deep infaunal species of Globobulimina and Chilostomella are generally absent. However, as in deeper-water settings, faunal composition changes with increasing eutrophication and hypoxia. Most miliolids disappear where hypoxia is severe (Platon et al., 2005). Species of Ammonia, which are very common in nearshore habitats, are particularly tolerant of eutrophic conditions whereas most species of another typical shallow-water genus, Elphidium, are much more sensitive. This contrast led Sen Gupta et al. (1996) to propose the ratio between the abundance of Ammonia and Elphidium (the "Ammonia-Elphidium index") as an indicator of hypoxia (see also Sen Gupta and Platon, 2006). Three other hyaline calcareous species, Pseudononion atlanticum, Epistominella vitrea and Buliminella morgani, flourish in low oxygen conditions on the Louisiana shelf and have been used as indicators (PEB index) of historic low oxygen in sediment core records (Osterman et al., 2003). These indices probably mainly reflect eutrophication, which is usually correlated with hypoxia.

Core records indicate that increased hypoxia/eutrophication leads to a depression in species richness and diversity in coastal and shelf areas (Nelsen et al. 1994, Platon et al., 2005), similar to that observed at upper bathyal depths (Gooday et al., 2000). Moreover, hypoxia, whether natural or human-induced, appears to impact foraminiferal assemblages in a similar way. For example, on the Louisiana shelf, Osterman et al. (2008) reported periodic peaks in the abundance of species tolerant to lower oxygen (the PEB index) extending back over the last 1000 years. These responses, which were presumably related to natural low-oxygen events fueled by terrestrial organic matter, resembled the rapid increase in the PEB index caused by the development of human-induced hypoxia since the 1950s in the same area. The current PEB index, however, is much higher than the periodic peaks in the $>100$ year record. In the Adriatic Sea, species typical of eutrophic conditions in front of the Po delta include Nonionella turgida, Hopkinsina pacifica, Stainforthia concava and several Bolivina species (Barmawidjaja et al., 1992; Jorissen et al., 1992). In a study on a sediment core taken off the Po delta, Barmawidjaja et al. (1995) tentatively explained the relative increase of these 
taxa starting in the 1960s as a response to the appearance of seasonal hypoxia in this area.

\subsection{Metazoan meiofauna}

Ecological studies on effects of hypoxia and anoxia on metazoan meiofauna are limited (Diaz and Rosenberg, 1995). Several field studies have demonstrated the sensitivity of metazoan meiobenthic animals to bottom-water hypoxia (e.g. Coull, 1969; Elmgren, 1975; Josefson and Widbom, 1988; Murrell and Fleeger, 1989; Moodley et al., 1997). The general consensus is that meiofaunal taxa are less affected by hypoxia than macrofauna and megafauna (e.g. Elmgren, 1975; Josefson and Widbom, 1988; Levin et al., 2002). Meiofauna also seem to be less sensitive to physical disturbance and destabilization of the sediment that may accompany hypoxia (e.g. Thistle, 1980; Austen et al., 1989; Warwick et al., 1990; Neira and Rackemann, 1996).

Among the metazoan meiofauna, nematodes, the numerically dominant and least motile meiofaunal taxon in subtidal soft sediment communities, are the most tolerant to low oxygen (Giere, 1993; Cook et al., 2000; Neira et al., 2001a). Several species are able to withstand anoxic conditions for over 60-78 days, although their densities decline (Wieser and Kanwisher, 1961; Moodley et al., 1997). Recent meiofaunal studies at three shelf and upper slope sites off Chile (north, off Antofagasta at $309 \mathrm{~m}$; central, off Concepcion at $366 \mathrm{~m}$; south, off Chiloe at $296 \mathrm{~m})(0-10 \mathrm{~cm}$; Veit-Kohler et al., 2009), and off Callao, Peru (94 m) (0-1 cm; Gutiérrez et al., 2008) confirm previous observations for the region (Neira et al., 2001a, 2001b) that nematodes are the dominant meiobenthic group at these depths and that they reach highest densities and biomass during periods of strong oxygen deficiency. Time series data off Callao, Peru (94 m), indicate fluctuations in nematode density and community dominance (up to $100 \%$ ), with a "nematode state" suggested to occur under extreme La Niña conditions when bottom-water oxygen concentrations are $<10 \mu \mathrm{M}\left(0.22 \mathrm{ml} \mathrm{L}^{-1}\right)$ and macrofaunal densities are reduced (Gutiérrez et al., 2008). Similar nematode trends have been observed in relation to low oxygen off central Chile (Neira et al., 2001a; Sellanes and Neira, 2006) and off Callao at $305 \mathrm{~m}$ (Neira et al., 2001b; Levin et al., 2002) during and after El Niño events.

In contrast, copepods and other crustaceans appear to be the meiofaunal groups most sensitive to anoxia (Coull, 1969; Elmgren, 1975; Heip, 1980; Murrel and Fleeger, 1989; Moodley et al., 1997). During 1985/1986, summer hypoxic conditions on the Louisiana shelf led to complete loss of harpacticoid copepods within a month, with lesser declines in nematode and kinorhynch densities. Copepods were slow to recover following return of normal oxygen conditions in the spring of the following year, further suggesting the sensitivity of copepods to hypoxia (Murrel and Fleeger, 1989).

Hypoxia can affect the vertical distribution and composition of nematode fauna. On the Swedish west coast,
Sabatieria pulchra, a species associated with the redox potential discontinuity, migrates vertically and is the only metazoan species present after summer hypoxia (Hendelberg and Jensen, 1993). Species of the same genus dominate bathyal sediments $(500 \mathrm{~m}$ and $1000 \mathrm{~m})$ off the Kenyan coast in the W Indian Ocean (Muthumbi et al., 2004). Subsurface fauna appear to be affected by hypoxia only in a narrow, shallow depth range, suggesting an upwards migration in response to increasing sulphide concentration (Hendelberg and Jensen 1993). Beneath fish farms in the western Mediterranean (Tyrrenian Sea), $74 \%$ of the meiofauna was concentrated in the top $1 \mathrm{~cm}$ compared to only $42 \%$ after the cages were removed (Mazolla et al. 2000).

In surface sediments, food availability is thought to play a more important role in regulating meiofaunal communities than oxygen, whereas oxygen supply is often the limiting factor in deeper sediments (Vanreusel et al., 1995). Organic load biodeposition of mussel and fish farms can also lead to oxygen depletion of bottom waters (e.g. Tsutsumi et al., 1991; Mazzola et al., 1999; Mirto et al., 2000, 2002). Because they are sensitive to changes in the environment, meiofauna have been suggested as initial indicators of benthic community structural response to fish farm biodeposition (Duplisea and Hargrave, 1996). In the Western Mediterranean (Tyrrhenian Sea), a strong impact on meiofauna assemblages was observed beneath fish cages. Meiofaunal densities (top $10 \mathrm{~cm}$ ) dropped about 3 fold as compared with a control site during the 8 months of sampling (Mazzola et al., 1999). Copepods and ostracods exhibited a significant decline in the farm sediment in the first three months; kinorhynchs disappeared completely at the farm site, whereas polychaete density did not vary (Mazzola et al., 1999). The nematode assemblage was highly impacted, with reduced densities, diversity and richness in sediment beneath the farm. There were also changes in functional indices; after 45 days of farming there was an increase in individual biomass and a different nematode assemblage. In another study in the same area, meiofaunal densities beneath a mussel farm were significantly lower $\left(1551\right.$ ind $\left.10 \mathrm{~cm}^{-2}\right)$ than at a control site $\left(2071\right.$ ind $\left.10 \mathrm{~cm}^{-2}\right)$ over 12 months. In this setting turbellarian, ostracod, and kinorhynch densities significantly decreased compared with a control site, while copepod densities remained constant or increased, possibly benefiting from enhanced microphytobentic biomass (Mirto et al., 2000). The observed changes in meiofaunal community structure are a combined response to increased organic load along with reduced oxygen penetration at the water-sediment interface.

\subsubsection{Meiofaunal recovery following hypoxia}

Meiofaunal organisms are known to be characterized by high turnover rates and hence rapid or short recovery times (e.g. Chandler and Fleeger, 1983; Alongi et al., 1983; Danovaro et al., 1995). Meiofaunal crustaceans such as copepods and 
ostracods can rapidly recover due to their motility. However, the speed and extent of meiofaunal colonization of defaunated sediments vary greatly. For example, Chandler and Fleeger (1983) showed that copepods and nauplii recolonized azoic estuarine sediments $(15 \times 28 \mathrm{~cm}$ chambers $)$ in only two days, whereas nematodes required 29 days. Subtidal experiments placing azoic sediment trays $(29 \times 34 \mathrm{~cm})$ revealed that copepods required five days to reach background densities, while for nematodes it took seven days (Alongi, 1981). Neira and Rackeman (1996) reported that meiofauna recolonized "black spots" $\left(1 \mathrm{~m}^{2}\right.$ patches of buried algae with reduced sediments lacking fauna) only after redevelopment of an oxidized sediment layer. In those places where the surface remained "black", the meiofauna did not re-establish or their abundances and taxon richness were very low for almost one year. Differences in recolonization modes of the meiofauna may be attributed to their motility, ability to become suspended, active swimming, as well as their vertical distribution in the sediment column (Jensen, 1983; Chandler and Fleeger, 1983; Bowman et al., 1984; Powell, 1989). Experimentally-induced hypoxia, created by covering $4 \times 4 \mathrm{~m}$ sediment plots with a polyethylene sheet, caused strong changes in nematode community composition on a tidal flat but did not result in complete nematode mortality (Van Colen et al., 2009), as was observed for the macrobenthos (Van Colen et al., 2008). Nematode recovery was rapid (1 month) but was strongly influenced over the long term by the dynamics of the macrobenthic bioturbation, grazing and resuspension (Van Colen et al., 2009).

The re-establishment of meiofauna in sediments previously affected by hypoxic bottom waters may occur by a combination of passive transport of sediment particles, and selective re-entry into the sediment, which is influenced by the physico-chemical features of the substrate (Palmer, 1988; Fleeger et al., 1990). Meiofauna, primarily copepods, ostracods, turbellarians, polychaetes and juvenile bivalves, are known to respond to environment deterioration by active migration away from the sediment (Bell and Sherman, 1980; Armonies, 1988, 1994; Wetzel et al., 2001). Nematodes are predominantly dispersed either passively by resuspension by currents, by locally restricted movements within the sediment, or by active swimming (Hagerman and Rieger, 1981; Chandler and Fleeger, 1983; Walters, 1988; Armonies, 1990, 1994). Thus it is not surprising that meiofauna are commonly early colonists (Rhoads et al., 1977), and that the most mobile and sensitive taxa (i.e., copepods) rapidly colonize sediments after favorable conditions return.

\subsection{Macrofauna and megafauna}

Detailed reviews of macrobenthic responses to hypoxia can be found in $\mathrm{Wu}$ (2002), which addresses molecular responses, Grieshaber et al. (1994), which considers physiological and metabolic responses, Diaz and Rosenberg (1995), which focuses on physiological and species-level attributes, Rosenberg (2001), which addresses functional groups and community succession, and Levin (2003), which reviews benthos within permanent oxygen minimum zones. Organism tolerances to hypoxia are treated in Rosenberg (1991) and Gray et al. (2002). Often the ecosystem responses are associated with organic enrichment; these are synthesized by Pearson and Rosenberg $(1978,1987)$ and Gray et al. (2002). Below we briefly review community changes and the ecosystem-level consequences expected along gradients of increasing hypoxia (decreasing oxygen) and recovery (increasing oxygen), and assess whether the source, frequency or intensity of hypoxia influences macrobenthic response.

First responses to hypoxia are usually behavioral or physiological. Tube lengthening or body extension into the water column occurs in a variety of polychaetes and amphipods (Tyson and Pearson, 1991; Nilsson and Rosenberg, 1994, 2000; Rosenberg et al., 2002). Related responses include shallowing of burial depth (Long et al., 2008), emergence from the sediment (Rabalais et al., 2001a), and the formation of aggregations that raise individuals into the water column (Stachowitsch, 1984; Baden et al., 1990). During September 1983 anoxia occurred in the Gulf of Trieste, covering at least $50 \mathrm{~km}^{2}$. Stachowitsch $(1984,1991,1992)$ made careful observations of sequential responses by epibenthos at $20-25 \mathrm{~m}$ water depth, providing a glimpse of relative tolerance. Initially brittle stars (Ophiothrix quinquemaculata) and holothurians (Cucumaria planci) detached from sponges and other hard substrate; some holothurians eviscerated. Burrowing holothurians, echinoids, mantis shrimp and ghost shrimp emerged from the sediment. Subsequently hermit crabs left their shells, bivalves and sipunculans emerged; crabs, gobies and flatfish died. Anemones and tunicates were among the last to die. The ophiuroids Amphiura filiformis and A. chiajei emerged from the sediment in experimental tests when oxygen fell to $0.85 \mathrm{ml} \mathrm{L}^{-1}$ and $0.54 \mathrm{ml} \mathrm{L}^{-1}$, respectively (Rosenberg et al., 1991). Ophiuroid aggregation and climbing behavior is also documented in the southeastern Kattegat (Baden et al., 1990) and Gulf of Mexico (see earlier text).

As hypoxia persists or its severity increases, mortality occurs. This can result from direct lethality, caused by low oxygen or presence of hydrogen sulfide, or from indirect causes such as increased susceptibility to predators (due to reduced burial and dwelling depths or less efficient foraging) (Long et al., 2002; Wu, 2002). Subsequent effects can be abrupt and involve sharp reductions in numbers of species, biomass and density and increased dominance by a few species (Harper et al., 1991; Rosenberg, 2001; Rabalais et al., 2001b).

Small body size, rapid growth rates, shallow dwelling zones, limited bioturbation, and annual life cycles are attributes of species that inhabit seasonally hypoxic settings. Seasonal hypoxia typically causes loss of species numbers, reduced biomass and increased dominance. Annelids (e.g. Heteromastus filiformis, Paraprionospio pinnata) and 
certain molluscs (e.g. Thyasira equalis, T. sarsi, Melinna cristata) prove most tolerant although even they can disappear completely when sulfide levels increase greatly (Josefson and Widbom, 1988; Nilsson and Rosenberg, 2000; Quiroga et al., 2007).

Diversity is the biological attribute most sensitive to hypoxia. Loss of hypoxia-intolerant taxa leads to greatly reduced species richness and evenness. Typically crustaceans and echinoderms disappear first, with annelids and selected molluscs exhibiting greatest tolerance to hypoxia (Diaz and Rosenberg, 1995; Gray et al., 2002). Under extreme oxygen depletion only a few species may persist and dominance is always high. Because hypoxia and eutrophication (or upwelling production) often co-occur it is difficult to separate their effects on diversity (Levin and Gage, 1998). Organic enrichment will strongly influence evenness and dominance. Another confounding factor is that hypoxic waters typically have low $\mathrm{pH}$, in part from $\mathrm{CO}_{2}$ buildup produced by respiration. In permanently hypoxic or suboxic waters, animals may be bathed in waters of $\mathrm{pH}<7.5$. Thus it is often difficult to distinguish effects of oxygen depletion from those of decreased $\mathrm{pH}$ on taxonomic composition in such regions. Calcifying taxa such as echinoderms, with highly soluble high$\mathrm{Mg}$ calcite, usually fare poorly in hypoxic settings (Levin, 2003).

Other attributes shaped by hypoxia include body-size structure and morphology. Smaller taxa typically prevail over larger forms due to their greater surface area to volume ratios that enhance diffusion (Levin, 2003). Smaller taxa that persist in hypoxic settings tend to be opportunistic, with high larval availability, rapid growth and short generation times (Wu, 2002). Branchiate species with prolific respiratory structures (gills, brachiae, palps and tentacles; Fig. 5) such as spionid, cirratulid and ampharetid polychaetes, seem to have an advantage in both oxygen acquisition (Lamont and Gage, 2000) and surface feeding, and may explain the predominance of surface-deposit feeding annelids in many enriched, hypoxic settings.

Animal vertical distributions in the sediment are typically predicted to become shallower under hypoxic conditions (Long et al., 2008). This seems to occur when hypoxia is episodic or seasonal, as seen in the northern Gulf of Mexico (Rabalais et al., 2001b). For the most part, deep burrowers disappear under hypoxic conditions and animal activities are focused near the sediment-water interface in most estuaries and continental shelves. However, in settings where taxa are adapted to naturally occurring, persistent low-oxygen conditions, a deepening of deposit-feeder vertical distributions is observed, perhaps associated with an enhanced chemosynthetic food supply (Smith et al., 2000; Rabalais et al., 2001; Levin et al., 2003, 2009).

Hypoxia-induced changes in the size, composition, diversity, feeding and dwelling habits of benthic macrofaunal communities have many functional consequences. These include shifts in trophic structure and food chain support func- tions, altered organic matter remineralization pathways, reductions in bioturbation and attendant oxygenation and carbon burial, and loss of habitat heterogeneity and key biogenic structure-forming species (e.g. mussel beds, oyster reefs, seagrasses) that act as ecosystem engineers (sensu Coleman and Williams, 2002).

As oxygen is depleted suspension feeders are replaced by deposit feeders, and deep-burrowing, subsurface-deposit feeders are replaced by shallow interface feeders. Predators decline along a hypoxia gradient in Hong Kong (Wu, 1982) and in Chesapeake Bay (Breitburg et al., 1994). Macrobenthos abundances are reduced, while meiobenthos abundances remain high, and eventually protozoans replace metazoans as biomass dominants and as key recyclers of organic carbon (Woulds et al., 2007). Under extreme conditions nearly all energy flows through microbes and trophic support for fisheries is curtailed or terminated. As animal biomass declines and activities are concentrated at shallower depths in the sediment column, particle mixing and solute pumping rates and depths diminish. There is a loss of geochemical heterogeneity in sediment and a reduction in organic matter remineralization and burial (see Middelburg and Levin, 2009). Loss of large-reef forming species reduces habitat complexity and water filtration capacity, two factors that are important to maintenance of system health and biodiversity (Coleman and Williams, 2002).

\subsubsection{Macrofaunal and megafaunal recovery}

Recovery of macrobenthos and megabenthos following coastal hypoxia can follow variable trajectories (e.g. Gutiérrez et al., 2008), sometimes with different successional patterns occurring at nearby sites (e.g. Harper et al., 1981). Sediment profile imagery and derivation of a benthic habitat quality index from the imagery defines four distinct successional stages following a 2-year reoxygenation of the Gullmar Fjord. These involve formation of microbial mats and absence of fauna in stage 0 , then increasing dwelling depths in the sediment column and degree of bioturbation. The recovery stages did not mirror the degradation stages, with Capitella capitata, the nemertean Hubrechtella dubia, and the heart urchins Echinocardium spp. colonizing at 85$95 \mathrm{~m}$ (Nilsson and Rosenberg, 2000; Rosenberg et al., 2002).

On the Texas inner shelf, recovery following acute hypoxia with hydrogen sulfide buildup involved colonization by Paraprionospio pinnata in deeper waters $(20 \mathrm{~m})$ and sequential succession of Magelona phyllesae, Abra aequalis, Balanoglossus sp. n., Natica pusilla, and Lembos brunneomaculata in shallower $(15 \mathrm{~m})$ waters. Ampeliscid amphipods, while not tolerant of severe hypoxia, are observed to be common just prior to hypoxic events (Harper et al., 1991) at oxygen minimum zone edges (Levin, 2003) and at the Mississippi River canyon (Soliman and Rowe, 2008), suggesting they may be organic enrichment opportunists that can serve as indicators of impending hypoxia. The ampeliscid 
amphipods, however, did not recruit back to the hypoxic zone studied by Harper et al. $(1981,1991)$ for several years and were completely absent from the benthic macroinfaunal community in severely hypoxic areas of the Louisiana continental shelf (Rabalais et al., 2001b).

Annual recovery is common to sites subject to predictable, seasonal hypoxia, such as Tampa Bay, Florida (Santos and Simon, 1980). Rapid growth, reproductive timing and dispersal potential all contribute to resiliency. Kiel Bay fauna (Arntz, 1981) and Tampa Bay fauna (Santos and Simon, 1980) are considered pre-adapted to hypoxia, with recovery occurring in 1 year. However, when hypoxia is not seasonal and occurs over longer periods, recovery following hypoxia can be delayed. Recovery of macro- and meiofauna following defaunation by hypoxia can take 18 months or more in settings as diverse as fjords (Josefson and Widbom, 1988; Austen and Widbom, 1991), the New Jersey shelf (Boesch and Rosenberg, 1981), the Adriatic Sea (Stachowitsch, 1991) and Hong Kong waters ( $\mathrm{Lu}$ and $\mathrm{Wu}, 2000)$. Additional factors, such as the presence of excessive organic debris and sulfide (Rosenberg, 1972, 1976; Leppakoski, 1975; Karakassis et al., 1999), limited exchange and recruit sources (Lardicii et al., 2001), altered salinity regimes, or recurring hypoxia (Gutiérrez et al., 2008), can all slow faunal recovery following hypoxia.

\subsection{Benthic and demersal fisheries resources}

The shelf and estuarine habitats most likely to experience hypoxia are also nutrient-rich areas that support abundant bottom fisheries, so there is strong interest in the effects of hypoxia on these resources (see review by Breitburg et al., 2009; Ekau et al., 2009). Hypoxia can affect fish and shellfish directly, by inducing behavioral avoidance, altering migration routes, reducing growth and reproduction, inhibiting immune responses or by causing mass mortality. However, often it is the indirect effects of severe hypoxia, including loss of prey and loss or compression of critical habitat including structural features that can have the greatest effect on demersal fisheries (Diaz and Breitburg, 2009).

Surprisingly, moderate or intermittent hypoxia can be linked to benefits for fishery species. The underlying source of hypoxia, nutrient enrichment, may yield elevated prey biomass systemwide, as in parts of the Baltic Sea (Elmgren, 1989). Oxygen-stressed infauna may move towards the sediment-water interface and provide an enhanced, readily accessible food supply to mobile fish and shellfish that can return to oxygenated waters after feeding. Demersal species that are able to tolerate low DO for short periods, (e.g., weakfish; Tuzzolino, 2008) can take advantage of enhanced prey availabililty. They also can obtain refuge from less tolerant predators. The widespread ability of fish and shellfish to swim away from hypoxic areas, combined with the facilitative effects described above, may explain why large-scale studies rarely demonstrate a clear negative relationship be- tween fishery landings and extent of hypoxia (Breitburg et al., 2009). However, the proportion of demersal fish and shellfish relative to pelagic fishes typically declines under conditions of extensive or permanent hypoxia, such as found in the Sea of Azov, the Black Sea, the Skagerrak-Kattegat and the Adriatic Sea (Caddy, 2000; de Leiva Moreno et al., 2000).

There are clear cases where hypoxia induces mass mortality or reduces catches locally. Sporadic declines in oxygen concentrations connected to thermohaline stratification occur quite frequently in shallow shelf waters such as the North Sea (Westernhagen and Dethlefsen, 1983) or Mid Atlantic Bight (Mountain, 2002) and in inshore bays, such as the Limfjord in Denmark (Jørgensen, 1980). During low-oxygen events in the North Sea, fish abundance dropped to 1 to $5 \mathrm{~kg}$ per $30 \mathrm{~min}$ trawl compared to the situation after remixing with 360 to $450 \mathrm{~kg}$ catch per trawl. Video images revealed that most mobile animals such as fish had left the area. This was in agreement with a similar event in the New York Bight in 1976 (Sindermann and Swanson, 1979). As oxygen depletions do not happen instantly, fish and other mobile animals normally have enough time to leave the endangered areas, and can repopulate the sites after the situation has improved. For sessile species that are hypoxia-tolerant, one consequence of reduced predation by fishes and megafaunal invertebrates may be enhanced survivorship. This may explain the sustained production of the harvested quahog clam Mercenaria mercenaria in hypoxic settings in Narragansett Bay, Rhode Island, USA (Altieri, 2008).

Most demersal fish species are sensitive to low oxygen and react to changes at a tolerance level of about $30 \%$ saturation $\left(2 \mathrm{ml} \mathrm{L}^{-1}\right)$. Miller et al. (2002) give an $\mathrm{LC}_{50}$ of 1.5 to $3 \mathrm{mg} \mathrm{L}^{-1}$ (1 to $2 \mathrm{ml} \mathrm{L}^{-1}$ ) for several coastal and estuarine fish. These species will readily detect decreasing oxygen and escape as early as possible. However, the less mobile members of the demersal community can experience extremely high mortality, depending on the rate of decrease of dissolved oxygen. Westernhagen and Dethlefsen (1983) observed up to $100 \%$ mortality in some ophiuroid species in their study. Some crustaceans can cope with $1 \mathrm{mg} \mathrm{L}^{-1}$ $\left(0.7 \mathrm{ml} \mathrm{L}^{-1}\right)$ (Miller et al., 2002) without showing significant change in behavior (Demers et al., 2006), but crayfish and lobsters cannot escape quickly and thus are highly vulnerable to events like the hydrogen sulfide eruptions that occur on the Namibian shelf. They become trapped by the upwelling anoxic waters and pushed towards the shore. In this case mobile species like fish also sometimes get trapped and washed ashore.

Another impact of strong hypoxia or anoxia is on the early life stages of some species. The best example maybe the Baltic cod, that lives in a strongly stratified environment where more saline but poorly oxygenated waters occur at greater depths. To maintain sperm activation and egg buoyancy, cod needs a minimum salinity of 11 (Nissling and Westin, 1997). Oxygen content of waters below the 


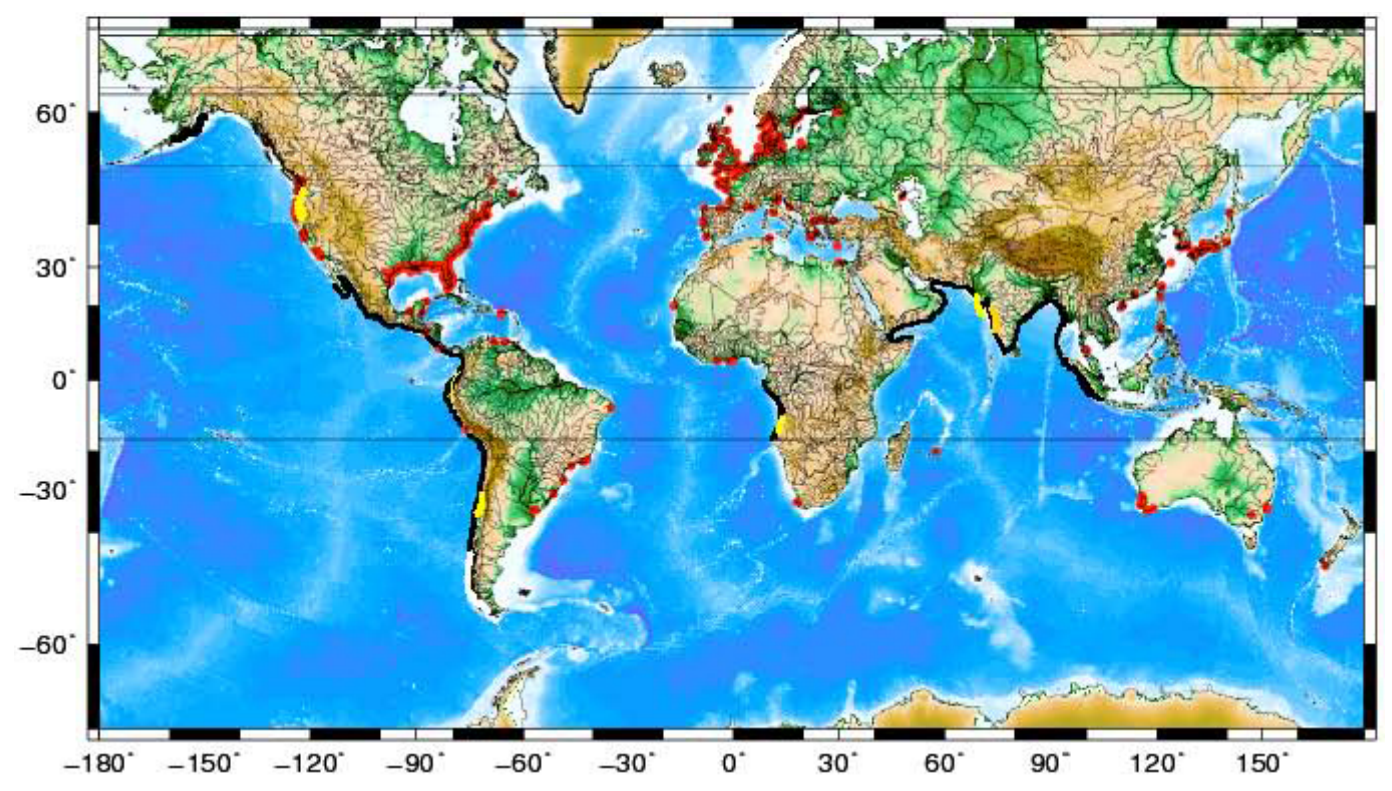

Fig. 7. World distribution of coastal hypoxia including eutrophication-induced coastal hypoxia (red, from Diaz and Rosenberg, 2008), outer shelf (200 m) hypoxia (black, from Garcia et al., 2006, World Ocean Atlas), and inner shelf hypoxia (yellow, see paper text).

thermocline has decreased in the Western Baltic Sea in recent decades (Gerlach, 1996). The habitat required for spawning (saturation $>30 \%$ and salinity $>11$ suitable for cod development) has diminished due to a continuously rising oxycline (Lozán et al., 1996; Nausch et al., 2003). The Bay anchovy is encountering similar difficulties in weakly stratified estuaries of Chesapeake Bay, where eggs sink into lethal hypoxic waters (Keister et al., 2000).

\section{Are there differences between human-caused vs. nat- ural coastal hypoxia?}

\subsection{Characteristics of human-induced and natural hy- poxia}

To compare benthic responses to natural versus humaninduced hypoxia, we must consider how the location, sources, timing, duration, areal extent, or intensity of hypoxia might differ when hypoxia is caused by human activities. Among the major factors contributing to hypoxia (nutrient enrichment, limited circulation, stratification, old water, or advection of low-oxygen water), the most direct human cause of hypoxia is nearly always eutrophication. At first glance, the occurrence of most eutrophication-related hypoxia differs in distribution from natural open shelf [OMZor climate-change related] hypoxia (Fig. 7). The east and west North Atlantic, along with the NW Pacific, support a majority of eutrophication-driven hypoxia records, which mainly occur in bays, estuaries, fjords and enclosed seas (Diaz and Rosenberg, 2008). In contrast, upwelling regions, including the Eastern Pacific, West Africa and Northern In- dian Ocean are all sites of natural shelf hypoxia. One hypothesis is that long-term exposure of ecosystems to natural upwelling and high production generates resistance to eutrophication. An alternative explanation is that regions with natural shelf hypoxia support smaller human populations with a smaller $\mathrm{N}$ footprint, or that these ecosystems are less well studied (leading to fewer records of human-induced hypoxia).

\subsection{Emergent responses to human-induced vs natural hypoxia}

Eutrophication, via riverine or atmospheric input of nutrients, or particulate organic matter (e.g., from fish food or sewage) will usually select for species that are enrichment opportunists (Table 1), and high abundance and species dominance (Table 2) will persist, or precede a crash. Similar characteristics are likely for shelf fauna exposed seasonally to upwelled, natural oxygen- depleted waters.

Often organic additions by human can exacerbate conditions in areas already susceptible to hypoxia due to natural topography (silled lochs and fjords, enclosed seas, estuaries), seasonal upwelling or to advection of low-oxygen water masses. The dramatic increase in incidence of hypoxia from cultural eutrophication in recent decades must be linked to human activities in hypoxia-conducive environments (Diaz and Rosenberg, 2008).

Less direct human influences such as altered coastline configurations and circulation, changes to freshwater or sediment supply, and global warming (with associated shifts in 
winds and precipitation) may generate hypoxia without massive eutrophication. Although both human and natural hypoxia can be regular, episodic or permanent, most humaninduced hypoxia is seasonal and localized, but persistent in recurrence on an annual basis (Diaz and Rosenberg, 2001, 2008). Recovery is possible, and conditions should select for infaunal species with annual (or shorter) life spans or mobile taxa able to migrate away from hypoxic areas. Early successional communities should dominate in regions subject to human-induced hypoxia, and composition should be temporally dynamic. While permanent hypoxia can be induced by humans in enclosed seas (Mee et al., 2005), it is more often a natural phenomenon that generates highly adapted, coevolved, low-diversity communities formed of species that can live and reproduce with surprisingly little oxygen (Karlson et al., 2002). The evolution of small body sizes, elaborate respiratory structures, ontogenetic migrations (into different oxygen zones), and chemosynthesis-based diets, are features of naturally hypoxic systems (Levin, 2003). Episodic reoxygenation events are also a natural phenomenon. Hurricanes in the Gulf of Mexico or El Niño conditions off Peru and Chile all act to temporarily dissipate hypoxia. Hypoxia in the Gulf of Mexico reforms within a week once the system has re-stratified. The capability of species to respond rapidly and positively to amelioration of hypoxia appears to be much greater in areas of natural hypoxia (Arntz et al., 2006).

Human-introduced hypoxia often occurs adjacent to large human populations, ie. mainly near river mouths or in enclosed bays in the Northern Hemisphere (Diaz and Rosenberg, 2008). For many of these areas, normoxia is the historical condition, and organisms have had little prior exposure to severe hypoxia. Thus, oxygen thresholds inhibiting growth and reproduction or inducing mortality are an order of magnitude higher than where hypoxia occurs naturally, and complete mortality of metazoans is more likely. In enclosed water bodies and along the coasts of the south eastern Pacific Ocean, off West Africa, and in the northern Indian Ocean, where hypoxia occurs naturally often over great expanses (Helly and Levin, 2004), a broader range of species are able to persist at near-anoxic conditions (reviewed in Levin, 2003).

\subsection{Interactions of hypoxia, climate change, and other human influences}

At some point the influences of nature and humans interact and cannot be distinguished in assessing benthic responses to hypoxia. Recent observations of declining oxygen and shoaling OMZs in the tropical oceans (Stramma et al., 2008), on the Oregon Coast (Grantham et al., 2004, Chan et al., 2008), and on the California coast (Bograd et al., 2008; McClatchie et al., personal communication) all introduce the possibility but claim uncertainty about the role of global warming in observed oxygen trends. Ocean warming can exacerbate hypoxia by reducing oxygen solubility, by increasing tem- perature stratification, by shifting upwelling or downwelling winds, and by altering circulation to enhance advection of low-oxygen water masses or reduce advection of oxygenated waters. Warming can increase storm incidence and thus increase oxygenation (Rabalais et al., 2009). It may also enhance respiration over production due to their differential temperature dependence. Untangling these different effects from each other and from human-induced eutrophication may be difficult. At the level of the individual, reduced oxygen supply to tissues can be the first mechanism to restrict whole-animal tolerance to thermal extremes. Hypoxia will exacerbate this limitation, and accelerate extinctions or relocations induced by warming (Pörtner and Knust, 2007).

In addition, hypoxia and warming will rarely be the sole factors acting to shape communities and ecosystems. Ammonium, hydrogen sulfide, organic carbon loading and acidification effects that accompany hypoxia will all have individual and synergistic effects (Wu, 2002). Hypoxia and low pH, for example, will reduce oyster defense against common diseases by lowering production of reactive oxygen intermediates (Boyd and Burnett, 1999), and increase the vulnerability of Humboldt squid (Dosidicus gigas) to predation by slowing metabolism (Rosa and Siebel, 2008). On larger scales, overfishing, other forms of pollution, habitat degradation and pressure from invasive species and diseases can all increase ecosystem susceptibility to disruption by hypoxia. Thus, predicting species, community or ecosystem responses to oxygen depletion in coastal settings requires a broader understanding of the context in which it occurs.

Acknowledgements. We thank SCOR for supporting the Working Group 128 that instigated this review. We thank D. Gilbert and all members of the SCOR Working Group on Coastal Hypoxia for exchange of ideas and for encouragement throughout. We thank Bronwen Currie for valuable input concerning the Nambian shelf, bacterial mat photographs, and access to Nambian worms. V. Gallardo provided access to images of bacteria from Concepcion Bay (FONDECYT Project 1070552); R. McLeod and S. Wing provided access to images of bacteria from Doubtful Sound, New Zealand. We thank D. Breitburg and D. Gutiérrez for providing access to their unpublished manuscripts, Garen Checkley for assistance drafting Fig. 1, R. Diaz for providing eutrophication-induced hypoxia locations plotted in Fig. 7 and John Helly and G. Mendoza for drafting Fig. 7. Three reviewers provided valuable comments on the manuscript. This research was partly supported by the US National Science Foundation, National Environmental Research Council and the Netherlands Organization for Scientific Research. AJG was partly supported by OCEANS 2025, a co-ordinated marine science programme of the Natural Environment Research Council (UK).

Edited by: D. Gilbert 


\section{References}

Abello, P. and Macpherson, E.: Distribution of Bathynectes piperitus (Brachyura: Portunidae) in the Benguela Upwelling Region and its relationship with some environmental parameters, J. Crustacean Biol., 9, 373-380, 1989.

Alongi, D. M.: Recolonization of meiobenthos in oiled azoic subtidal muddy sands of the York River estuary, Virginia, M.A thesis, College of Williams and Mary, Virginia, 96 pp., 1981.

Alongi, D. M., Boesch, D. F., and Diaz, R. J.: Colonization of meiobenthos in oil-contaminated sands of the lower Chesapeake Bay, Mar. Biol., 72, 325-335, 1983.

Altieri, A. H.: Dead zones enhance key fisheries species by providing predation refuge, Ecology, 89, 2808-2818, 2008.

Andersin, A. B., Lassig, J., Parkkonen, L., and Sandler, H.: The decline of macrofauna in the deeper parts of the Baltic proper and the Gulf of Finland, Kieler Meeresforsch., Sonderheft, 4, 23-52, 1978.

Ansari, Z. A., Harkantra, S. N., Nair, S. A., and Parulekar, A. H.: Benthos of the Bay of Bengal: A preliminary report, Mahasagar, 10, 55-60, 1977.

Ansari, Z. A., Rodrigues, C. L., Chatterji, A., and Parulekar, A. H.: Distributions of meiobenthos and macrobenthos at the mouths of some rivers of the East Coast of India, Indian J. Mar. Sci., 11, 341-343, 1982.

Armonies, W.: Active emergence of meiofauna from intertidal sediments, Mar. Ecol.-Prog. Ser., 43, 151-154, 1988.

Armonies, W.: Short-term changes of meiofaunal abundance in intertidal sediments, Helgolander Meeresun., 44, 375-386, 1990.

Armonies, W.: Drifting meio- and macrobenthic invertebrates on tidal flats in Königshaven: a review. Helgolander Meeresun., 48, 299-320, 1994.

Arntz, W. E., Gallardo, V. A., Gutiérrez, D., Isla, E., Levin, L. A., Mendo, J., Neira, C., Rowe, G., Tarazona J., and Wolff, M.: ENSO and similar perturbation effects on the benthos of the Humboldt, California and Benguela Current upwelling ecosystems, Adv. Geosci., 6, 243-265, 2006,

http://www.adv-geosci.net/6/243/2006/.

Arntz, W. E., Valdivia, E. and Zeballos, J.: Impact of El Niño 198283 on the commercially exploited invertebrates (mariscos) of the Peruvian shore, Meeresforschung, 32, 3-22, 1988.

Arntz, W. E.: Zonation and dynamics of macrobenthos biomass in an area stressed by oxygen deficiency, in: Stress Effects on Natural Ecosystems, edited by: Barrett, G. W. and Rosenberg, R., Wiley\&Sons Ltd., Chichester, 215-225, 1981.

Austen, M. C. and Widbom, B.: Changes in and slow recovery of a meiobenthic nematode assemblage following a hypoxic period in the Gullmar Fjord basin, Sweden, Mar. Biol., 111, 139-145, 1991.

Austen, M. C., Warwick, R. M., and Rosado, M. C.: Meiobenthic and macrobenthic community structure along a putative pollution gradient in southern Portugal, Mar. Pollut. Bull., 20, 398-404, 1989.

Baden, S. P., Loo, L.-O., Pihl, L., and Rosenberg, R.: Effects of eutrophication on benthic communities including fish: Swedish west coast, Ambio, 19, 113-122, 1990.

Baily, G. W., Beyers, C. J. De B., and Lipschitz, S. R.: Seasonal variation of oxygen deficiency in waters off southern south west Africa in 1975 and 1976 and its relation to the catchability and distribution of the Cape rock lobster Jasus lalandii, S. Afr. J.
Marine Sci., 3, 197-214, 1985.

Bakun, A. and Weeks, S.: Adverse feedback sequences in exploited marine systems: are deliberate interruptive actions warranted?, Fish Fish., 7, 316-333, 2006.

Banse, K.: On upwelling and bottom-trawling off the southwest coast of India, J. Mar. Biol. Assoc. India, 1, 33-49, 1959.

Barmawidjaja, D. M., Jorissen, F. J., Puskaric, S., and Van der Zwaan, G. J.: Microhabitat selection by benthic Foraminifera in the Northern Adriatic Sea, J. Foramin. Res., 22, 297-317, 1992.

Barmawidjaja, D. M., van der Zwaan, G. J., Jorissen, F. J., and Puškarik, S.: 150 years of eutrophication in the northern Adriatic Sea: Evidence from benthic foraminiferal records, Mar. Geol., 122, 367-384, 1995.

Bell, S. S. and Sherman, K. M.: A field investigation of meiofaunal dispersal: tidal resuspension and implications, Mar. Ecol.-Prog. Ser., 3, 245-249, 1980.

Bernhard, J. M., Buck, K. R., Farmer, M. A., and Bowser, S. S.: The Santa Barbara Basin is a symbiosis oasis, Nature, 403, 7780, 2000

Bernhard, J. M.: Potential symbionts in bathyal foraminifera, Science, 299, p. 861, 2003.

Bernhard, J. M. and Sen Gupta, B. K.: Foraminifera in oxygendepleted environments, in: Modern Foraminifera, edited by: Sen Gupta, B. K., Kluwer Academic Publishers, Dordrecht, Boston, London, 201-216, 1999.

Bernhard, J. M. and Bowser, S. S.: Benthic foraminifera of dysoxic sediments: chloroplast sequestration and functional morphology, Earth-Sci. Rev., 46, 149-165, 1999.

Bernhard, J. M. and Bowser, S. S.: Peroxisome proliferation in foraminifera inhabiting the chemocline: an adaptation to reactive oxygen species exposure?, J. Eukaryot. Microbiol., 55, 135-44, 2008.

Bernhard, J. M., Habura, A., and Bowser, S. S.: An endobiontbearing allogromiid from the Santa Barbara Basin: Implications for the early diversification of foraminifera, J. Geophys. Res., 111, G03002, doi:10.1029/2005JG000158, 2006.

Boesch, D. F., Diaz, R. J., and Virnstein, R. W.: Effects of tropical storm Agnes on soft bottom macrobenthic communities of the James and York River estuaries and the bay mouth, Chesapeake Sci., 17, 246-259, 1976

Boesch, D. F. and Rosenberg, R.: Response to stress in marine benthic communities, in: Stress effects on natural ecosystems, edited by: Barrett, G. W. and Rosenberg, R., John Wiley, Chichester, 179-200, 1981.

Bograd, S. J., Castro, C. G., Di Lorenzo, E., Palacios, D. M., Bailey, H., Gilly, W., and Chavez, F. P.: Oxygen declines and the shoaling of the hypoxic boundary in the California Current, Geophys. Res. Lett., 35, LI2607, doi:10.1029/2008GL034185, 2008.

Bowman, L. A., Romeyn, K. and Admiral., W.: On the ecology of meiofauna in an organically polluted estuarine mudflat, Estuar. Coast. Shelf S., 19, 633-653, 1984.

Boyd, J. N. and Burnett, L. E.: Reactive oxygen intermediate production by oyster hemocytes exposed to hypoxia, J. Exp. Biol., 202, 3135-3143, 1999.

Brand, T. D. and Griffiths, C.: Seasonality in the hydrography and biogeochemistry across the Pakistan margin of the NW Arabian Sea, Deep-Sea Res. Pt. II., 56, 283-295, 2009.

Bricker, S., Longstaff, B., Dennison, W., Jones, A., Boicourt, K., Wicks, C., and Woerner, J.: Effects of nutrient enrichment in the 
nation's estuaries: a decade of change, NOAA Coastal Ocean Program Decision Analysis Series No. 26, National Centers for Coastal Ocean Science, Silver Spring, MD, 2007.

Breitburg, D. L.: Episodic hypoxia in the Chesapeake Bay: interacting effects of recruitment, behavior and a physical disturbance, Ecological Monographs, 62, 525-546, 1992.

Breitburg, D. L., Pihl, L., and Kolesar, S. E.: Effects of low dissolved oxygen on the behavior, ecology and harvest of fishes: a comparison of the Chesapeake Bay and Baltic-Kattegat Systems, in: Coastal and estuarine studies: coastal hypoxia consequences for living resources and ecosystems, edited by: Rabalais, N. N. and Turner, R. E., American Geophysical Union, Washington, D. C., 293-310, 2001.

Breitburg, D. L., Hondorp, D. W., Davias, L. A. and Diaz, R. J.: Hypoxia, nitrogen and fisheries: Integrating effects across local and global landscapes, Annu. Rev. Mar. Sci., 1, 329-349, 2009.

Brietburg, D. L. and Fulford, R. S.: Oyster-sea nettle interdependence and altered control within the Chesapeake Bay ecosystem, Estuaries Coasts, 29, 776-784, 2006.

Breitburg, D. L., Steinberg, N., DuBeau, S., Cooksey, C., and Houde, E.D.: Effects of low dissolved oxygen on predation on estuarine fish larvae, Mar. Ecol.-Prog. Ser., 104, 235-246, 1994.

Brüchert, V., Jørgensen, B. B. Neumann, K., Reichmann, D., Schlösser, M., and Schulz, H.: Regulation of bacterial sulphate reduction and hydrogen sulfide fluxes in the central Namibian coastal upwelling zone, Geochim. Cosmochim. Ac., 67, 45054518, 2003.

Brüchert, V., Currie, B., Peard, K. R., Lass, U., Endler, R., Dübecke, A., Julies, E., Leipe, T., and Zitzmann, S.: Biogeochemical and physical control of shelf anoxia and water column hydrogen sulphide in the Benguela coastal upwelling system, in: Past and Present Water Column Anoxia, edited by: Neretin, L. N., Springer, New York, 161-193, 2006.

Burkholder, J. M., Tomasko, D. A., Touchette, B. W.: Seagrasses and eutrophication, J. Exp. Mar. Biol. Ecol., 350, 46-72, 2007.

Caddy, J. F.: Toward a comparative evaluation of human impacts on fishery systems of enclosed and semi-enclosed seas, Rev. Fish. Sci., 1, 57-95, 1993.

Caddy, J. F.: Marine catchment basin effects vs impacts of fisheries on semi-enclosed seas, ICES J. Mar. Sci., 57, 628-640, 2000.

Cahoon, L. B., Laws R. A., and Thomas C. J.: Viable diatoms and chlorophyll a in continental slope sediments off Cape Hatteras, North Carolina, Deep-Sea Res. Pt. II, 41, 767-782, 1994.

Carruthers, J. N., Gogate, S. S., Naidu, J. R and Laevastu, T.: Shoreward upslope of the layer of minimum oxygen off Bombay: its influence on marine biology, especially fisheries, Nature, 183, 1084-1087, 1959.

Chan, F., Barth, J. A., Lubchenco, J., Kirincich, A., Weeks, H., Peterson, W. T., and Menge, B. A.: Emergence of anoxia in the California Current large marine ecosystem, Science, 319, 920, 2008.

Chandler, G. T. and Fleeger, J. W.: Meiofaunal colonization of azoic estuarine sediment in Louisiana: mechanisms of dispersal, J. Exp. Mar. Biol. Ecol., 69, 175-188, 1983.

Chen, C.-C., Gong, G.-C., and Shiah, F.-K.: Hypoxia in the East China Sea: one of the largest coastal low-oxygen areas in the world, Mar. Environ. Res., 64, 399-408, 2007.

Cockroft, A. C.: Jasus lalandii "walkouts" or mass strandings in South Africa during the 1990's: an overview, Mar. Freshwater
Res., 52, 1085-1094, 2001.

Coleman, F. C. and Williams, S. L.: Overexploiting marine ecosystem engineers: potential consequences for biodiversity, TREE, 17, 40-44, 2002.

Conley, D. J., Carstensen, J., Ærtebjerg, G., Christensen, P. B., Dalsgaard, T., Hansen, J. L. S., and Josefson, A. B.: Long-term changes and impacts of hypoxia in Danish coastal waters, Ecol. Appl., 17, S165-S184, 2007.

Connolly, T. P., Hickey, B. M., and Geier, S. L.: Seasonal and event-scale processes contributing to hypoxia on the continental shelf of Washington, ASLO Ocean Sciences Abstract, Orlando, Florida, 2008.

Cook, A. A., Lambshead, P. J. D., Hawkins, L. E., Mitchell, N., and Levin, L. A.: Nematode abundance at the oxygen minimum zone in the Arabian Sea, Deep-Sea Res. Pt. II, 4, 75-85, 2000.

Copenhagen, W. J.: The periodic mortality of fish in the Walvis region. A phenomenon within the Benguela current, Dept. of Commerce and Industries, Division of Fisheries, Investigational Report 14, 1-33, 1953.

Coull, B. C.: Hydrographic control of meiobenthos in Bermuda, Limnol. Oceanogr., 14, 953-957, 1969.

Craig, J. K. and Crowder, L. B.: Hypoxia-induced habitat shifts and energetic consequences in Atlantic croaker and brown shrimp on the Gulf of Mexico shelf, Mar. Ecol.-Prog. Ser., 294, 79-94, 2005.

Crawford, R. J. M. and Dyer, B. M.: Responses by four seabird species to a fluctuating availability of Cape anchovy Engraulis capensis off South Africa, Ibis, 137, 329-339, 1995.

Cronin, T. M. and Vann, C. D.: The sedimentary record of climatic and anthropogenic influence on the Patuxent Estuary and Chesapeake Bay ecosystems, Estuaries, 26, 196-209, 2003.

Cury, P. and Shannon, L.: Regime shifts in upwelling ecosystems: observed changes and possible mechanisms in the northern and southern Benguela, Prog. Oceanogr., 60, 223-243, 2004.

Danovaro, R., Fraschetti, S., Belgrano, A., Curini-Galletti, M., Vincx, M., Albertelli, G., and Fabiano, M.: The potential impact of meiofauna on the recruitment of macrobenthos in a subtidal coastal benthic community of the Ligurian Sea: a field result, in: Proceedings of the 24th European Marine Biology Symposium, edited by: Eleftheriou, A., Ansell, A. D., and Smith, C. J., Olsen and Olsen, Fredensborg, DK, 115-122, 1995.

Daoji, L., Zahng, J., Huang, D., Wi, Y., and Liang, J.: Oxygen depletion in the Changiang (Yangtze) estuary, Sci. China Ser. D, 32, 686-694, 2002.

Dauer, D. M., Rodi, A. J., and Ranasinghe, J. A.: Effects of low dissolved oxygen on the macrobenthos of the lower Chesapeake Bay, Estuaries, 15, 384-391, 1992.

de Leiva Moreno, J. I., Agostini, V. N., Caddy, J. F., and Carocci, F.: Is the pelagic-demersal ratio from fishery landings a useful proxy for nutrient availability? a preliminary data exploration for the semi-enclosed seas around Europe, ICES J. Mar. Sci., 57, 1091-1102, 2000.

Demers, A., Souty-Grosset, C., Trouilhé, M., Füreder, L., Renai, B., Gherardi, F.: Tolerance of three European native species of crayfish to hypoxia, Hydrobiologia, 560, 425-432, 2006.

Diaz, R. J. and Breitburg, D. L.: The hypoxic environment. Ch. 1, in: Fish Physiology, Hypoxia. Volume 27, edited by: Richards, J. G., Elsevier Inc., New York, 2009.

Diaz, R. J. and Rosenberg, R.: Marine benthic hypoxia: A review 
of its ecological effects and the behavioural responses of benthic macrofauna, Oceanogr. Mar. Biol., 33, 245-303, 1995.

Diaz, R. J. and Rosenberg, R.: Overview of anthropogenicallyinduced hypoxic effects on marine benthic fauna, in: Coastal and estuarine studies: coastal hypoxia consequences for living resources and ecosystems, edited by: Rabalais, N. N. and Turner, R. E., American Geophysical Union, Washington, D. C., 129145,2001

Diaz, R. J. and Rosenberg, R.: Spreading dead zones and consequences for marine ecosystems, Science, 321, 926-929, 2008.

Ding, H. and Valentine, D. L.: Methanotrophic bacteria occupy benthic microbial mats in shallow marine hydrocarbon seeps, Coal Oil Point, California. J. Geophys. Res.-Biogeosciences, 113, G01015, doi:10.1029/2007JG000537, 2008.

Dingle, R. V.: Continental shelf upwelling and benthic Ostracoda in the Benguela System (southwestern Atlantic Ocean), Mar. Geol., 122, 207-225, 1995.

Duarte, C. M.: Submerged aquatic vegetation in relation to different nutrient regimes, Ophelia, 41, 87-112, 1995.

Duplisea, D. E. and Hargrave, B. T.: Response of meiobenthic size structure, biomass and respiration to sediment organic enrichment, Hydrobiol., 339, 161-170, 1996.

Ekau, W, Auel, H., Pörtner, H.-O., and Gilbert, D.: Impacts of hypoxia on the structure and processes in the pelagic community (zooplankton, macro-invertebrates and fish), Biogeosci. Discuss., 6, 5073-5144, 2009

Elmgren, R.: Benthic meiofauna as indicator of oxygen conditions in the northern Baltic proper, Merentutkimuslait. Julk. Havsforskningsinst. Skr., 239, 265-271, 1975.

Elmgren, R.: Man's impact on the ecosystem of the Baltic Sea: energy flows today and at the turn of the century, Ambio, 18, 326-332, 1989.

Emeis, K.-C., Brüchert, V., Currie, B., Endler, R., Ferdelman, T., Kiessling, A., Leipe, T., Noli-Peard, K., Struck, U., and Vogt, T.: Shallow gas in shelf sediments off the Namibian coastal upwelling ecosystem, Cont. Shelf Res., 24, 627-642, 2004.

Espino, M., Benites, C., and Maldonado, M.: Situación de la población de merluza durante "El Niño", in: El Niño. Su impacto en la fauna marina, edited by: Arntz, W. E., Landa, A., and Tarazona, J., Bol. Inst. Mar Peru-Callao, spec. vol., 159-162, 1985.

Fleeger, J. W., Palmer, M. A., and Moser, E. B.: On the scale aggregation of meiobenthic copepods on a tidal mudflat, PSZNI Mar. Ecol., 11, 227-237, 1990.

Flemer, D. A., Kruczynski, W. L., Ruth, B. F., and Bundrick, C. M.: The relative influence of hypoxia, anoxia, and associated environmental factors as determinants of macrobenthic community structure in a Northern Gulf of Mexico estuary, J. Aq. Ecosys. Stress and Recovery, 6, 311-328, 1999.

Flynn, B. A. and Gibbons, M. J.: A note on the diet and feeding of Chrysaora hysoscella in Walvis Bay Lagoon, Namibia, during September 2003, S. Afr. J. Marine Sci., 29, 303-307, 2007.

Fonselius, S.: Oxygen and hydrogen sulphide conditions in the Baltic Sea, Mar. Pollut. Bull., 12, 287-194, 1981.

Gallardo, V. A.: Notas sobre la diversidad de la fauna bentónica sublitoral del norte de Chile, Gayana (Zoología), 10, 3-15, 1963.

Gallardo, V. A.: Large benthic microbial communities in sulfide biota under Perú-Chile subsurface countercurrent, Nature, 268, 331-332, 1977.
Gallardo, V., Cañete, J. I., Roa, R., Enriquez-Briones, S., and Baltazar, M.: Recruitment of the squat lobster Pleuroncodes monodon on the continental shelf off Central Chile, J. Crustacean Biol. 14, 665-669, 1994.

Gallardo, V. A. and Espinoza, C.: New communities of large filamentous sulfur bacteria in the eastern South Pacific, Int. Microbiol., 10, 97-102, 2007.

Gallardo, V. A., Klingelhoffer, E., Arntz, W. E., and Graco, M.: First report of the bacterium Thioploca in the Benguela ecosystem off Namibia, J. Mar. Biol. Assoc. UK, 78, 1007-1010, 1998.

Garcia, H. E., Locarnini, R. A., Boyer, T. P. and Antonov, J. I.: Volume 3: dissolved oxygen, apparent oxygen utilization, and oxygen saturation, edited by: Levitus, S., NOAA Atlas NESDIS 64, U.S. Government Printing Office, Washington, D.C., 396 pp., 2006.

Gerlach, S. A.: Ökologische Veränderungen in der Kieler Bucht, in: Warnsignale aus der Ostsee, edited by: Lozán, L. J., Lampe, R., Matthäus, W., Rachor, E., Rumohr, H., and Westernhagen, H. V., Parey, Berlin, 259-266, 1996.

Giere, O.: Meiobenthology. The microscopic fauna in aquatic sediments, Springer, Berlin, 328 pp., 1993.

Gillibrand, P. A., Turrell, W. R., Moore, W. R. and Adams, R. D.: Bottom water stagnation and oxygen depletion in a Scottish sea loch, Estuar. Coast. Shelf Sci., 43, 217-235, 1996.

Glud, R., Rysgaard, S., Fenchel, T., and Nielsen, P.: A conspicuous $\mathrm{H}_{2} \mathrm{~S}$-oxidizing microbial mat from a high-latitude Arctic fjord (Young Sound, NE Greenland), Mar. Biol., 145, 51-60, 2004.

Gooday, A. J.: Benthic foraminifera (Protista) as tools in deep-water palaeoceanography: a review of environmental influences on faunal characteristics, Adv. Mar. Biol., 46, 1-90, 2003.

Gooday, A. J., Bernhard, J. M., Levin, L. A., and Suhr, S. B.: Foraminifera in the Arabian Sea oxygen minimum zone and other oxygen deficient settings: taxonomic composition, diversity, and relation to metazoan faunas, Deep-Sea Res. Pt. II, 47, 25-54, 2000.

Gooday, A. J., Jorissen, F., Levin, L. A., Middelburg, J. J., Naqvi, S. W. A., Rabalais, N. N., Scranton, M., and Zhang, J.: Historical records of coastal eutrophication-induced hypoxia, Biogeosciences, 6, 1707-1745, 2009, http://www.biogeosciences.net/6/1707/2009/.

González, R. R. and Quiñones, R. A.: Pyruvate oxidoreductases involved in glycolytic anaerobic metabolism of polychaetes from the continental shelf off central-south Chile, Estuar. Coast. Shelf S., 51, 507-519, 2000.

Grantham, B. A., Chan, F., Nielsen, K. J., Fox, D. S., Barth, J. A., Huyer, A., Lubchenco, J., and Menge, B. A.: Upwelling-driven nearshore hypoxia signals ecosystem and oceanographic changes in the northeast Pacific, Nature, 429, 749-754, 2004.

Graco, M., Farias, L., Molina, V., Gutierrez, D., and Nielsen, L. P.: Massive developments of microbial mats following phytoplankton blooms in a naturally eutrophic bay: implications for nitrogen cycling, Limnol. Oceanogr., 46, 821-832, 2001.

Gray, J. S., Wu, R. S.-S., and Or, Y. Y.: Effects of hypoxia and organic enrichment on the coastal marine environment, Mar. Ecol.Prog. Ser., 238, 249-279, 2002.

Grieshaber, M. K., Hardewig, I., Kreutze, U., and Pörtner, H. O.: Physiological and metabolic responses to hypoxia in invertebrates, Rev. Physiol. Bioch. P., 125, 43-147, 1994.

Gulin, M. and Kovalevsky, A. O.: Changes with depth in the Black 
Sea benthic redox-environment with regard to oxygen availability for deep-sea fauna, Geophys. Res. Abstr., 10, EGU2008-A01250, 2008.

Gutiérrez, D., Aronés, K., Chang, F., Quipúzcoa, L. and Villanueva, P.: Impact of the seasonal and interannual oceanographic variation on the assemblages of microphytoplankton, mesozooplankton, ichtyoplankton and macrozoobenthos in two coastal areas of northern Perú from 1994 to 2002, Boletín del Instituto del Mar del Perú, 22, 1-61, 2005.

Gutiérrez, D., Enriquez, E., Purca, S., Quipuzcoa, L., Marquina, R., Flores, G., and Graco, M.: Oxygenation episodes on the continental shelf of central Peru: remote forcing and benthic ecosystem response, Prog. Oceanogr., 79, 177-189, doi:10.1016/j.procean.2008.10.025, 2008.

Gutiérrez, D., Gallardo, V. A., Mayor, S., Neira, C., Vasquez, C., Sellanes, J., Rivas, M., Soto, A., Carrasco, F. D., and Baltazar, M.: Effects of dissolved oxygen and organic matter reactivity on macrofaunal bioturbation potential in sublittoral bottoms off central Chile during 1997-1998 El Niño, Mar. Ecol.-Prog. Ser., 202, 81-99, 2000.

Hagermann, G. M. and Rieger, R. M.: Dispersal of benthic meiofauna by wave and current action in Bogue South, North Carolina, USA, PSZNI Mar. Ecol., 2, 245-270, 1981.

Hagy, J. D., Boynton, W. R., Keefe, C. W., and Wood, K. V.: Hypoxia in Chesapeake Bay, 1950-2001: Long-term change in relation to nutrient loading and river flow, Estuaries, 27, 634-658, 2004.

Hamukuaya, H., O’Toole, M. J., and Woodhead, P. J. M.: Observations of severe hypoxia and offshore displacement of cape hake over the Namibian shelf in 1994, S. Afr. J. Marine Sci., 19, 5759, 1998.

Harper, D. E., Jr., McKinney, L. D., Nance, J. M. and Salzer, R. R.: Recovery responses of two benthic assemblages following an acute hypoxic event on the Texas continental shelf, northwestern Gulf of Mexico, in: Modern and ancient continental shelf anoxia, edited by: Tyson, R. V. and Pearson, T. H., Geological Society Special Publ., London, 58, 49-64, 1991.

Harper Jr., D. E., McKinney, L. D., Salzer, R. R., and Case, R. J.: The occurrence of hypoxic bottom water off the upper Texas coast and its effects on the benthic biota, Contrib. Mar. Sci., 24, 53-79, 1981.

Heip, C. H. R.: Meiobenthos as a tool in assessment of marine environmental quality, Rapp. PV Reun. Cons. Int. Explor. Mer., 179, 182-187, 1980.

Helly, J. and Levin, L. A.: Global distribution of naturally occurring marine hypoxia on continental margins, Deep-Sea Res. Pt. I, 51, 1159-1168, 2004.

Hendelberg, M. and Jensen, P.: Vertical distribution of the nematode fauna in a coastal sediment influenced by seasonal hypoxia in the bottom water, Ophelia, 83-94, 1993.

Holland, A. F., Shaughnessy, A. T. and Heigel, M. H.: Long-term variation in the mesohaline Chesapeake Bay macrobenthos: Spatial and temporal patterns, Estuaries, 10, 370-278, 1987.

Holland, A. F., Mountford, N. K., and Mihursky, J. A.: Temporal variation in upper bay mesohaline benthic communities, Chesapeake Sci., 16, 370-378, 1977.

Howell, P. and Simpson, D.: Abundance of marine resources in relation to dissolved oxygen in Long Island Sound, Estuaries, 17, 394-402, 1994.
Hughes, D. A., Lamont, P. A., Levin, L. A., Packer, M., and Gage, J. D.: Macrofaunal communities and sediment structure across the Pakistan Margin oxygen minimum zone, north-east Arabian Sea, Deep-Sea Res. Pt. II, 56, 434-448, 2009.

Jayaraj, K. A., Jayalakshmi, K. V., and Saraladevi, K.: Influence of environmental properties on macrobenthos in the northwest Indian Shelf, Environ. Monit. Assess., 127, 459-475, 2007.

Jensen, P.: Meiofaunal abundance and vertical zonation in a sublittoral soft bottom, with a test of the Haps corer, Mar. Biol., 74, 319-326, 1983.

Jørgenesen, B. B. and Gallardo, V. A.: Thioploca spp.: filamentous sulfur bacteria with nitrate vacuoles, FEMS Microbiol. Ecol., 28, 301-313, 1999.

Jørgensen, B. B.: Seasonal oxygen depletion in the bottom water of a Danish fjord and its effect on the benthic community, Oikos, 34, 68-76, 1980.

Jorissen, F.: Benthic foraminiferal microhabitats below the sediment-water interface, in: Modern Foraminifera, edited by: Sen Gupta, B. K., Kluwer Academic Publishers, Dordrecht, The Netherlands, 161-179, 1999.

Jorissen, F. J., Barmawidjaja, D. M., Puskaric, S. and Van der Zwaan, G. J.: Vertical distribution of benthic foraminifera in the northern Adriatic Sea: the relation with the organic flux, Mar. Micropaleontol., 19, 131-146, 1992.

Jorissen, F., Fontanier, C., and Thomas, E.: Paleoceanographical proxies based on deep-sea benthic foraminiferal assemblage characteristics, in: Proxies in Late Cenozoic Paleoceanography, edited by: Hillaire-Marcel, C. and de Vernal, A., Elsevier, Amsterdam, The Netherlands, 263-325, 2007.

Josefson, A. B. and Widbom, B.: Differential response of benthic macrofauna and meiofauna to hypoxia in the Gullmar Fjord basin, Mar. Biol., 100, 31-40, 1988.

Karakassis, I., Hatziyanni, E., Tsapakis, M., and Plaiti, W.: Benthic recovery following cessation of fish farming: a series of successes and catastrophes, Mar. Ecol.-Prog. Ser., 184, 205-218, 1999.

Karlson, K., Rosenberg, R., and Bonsdorff, E.: Temporal and spatial large-scale effects of eutrophication and oxygen deficiency of benthic fauna in Scandinavian and Baltic waters - a review, Oceanogr. Mar. Biol., 40, 427-489, 2002.

Keister, J. E., Houde, E. D., and Breitburg, D. L.: Effects of bottomlayer hypoxia on abundances and depth distributions of organisms in Patuxent River, Chesapeake Bay, Mar. Ecol.-Prog. Ser., 205, 43-59, 2000.

Lamont, P. A. and Gage, J. D.: Morphological responses of macrobenthic polychaetes to low oxygen on the Oman continental slope, NW Arabian Sea, Deep-Sea Res. Pt. II, 47, 9-24, 2000.

Lardicci, C., Como, S., and Rossi, F.: Recovery of the macrozoobenthic community after severe dystrophic crises in a Mediterranean coastal lagoon (Orbetello, Italy), Mar. Pollut. Bull., 42, 202-214, 2001.

Larkin, K. E. and Gooday, A. J.: Foraminiferal faunal responses to monsoon-driven changes in organic matter and oxygen availability at $140 \mathrm{~m}$ and $300 \mathrm{~m}$ water depth in the NE Arabian Sea, Deep-Sea Res. Pt. II, 56, 403-421, 2009.

Larson, F. and Sundbäck, K.: Role of microphytobenthos in recovery of functions in a shallow-water sediment system after hypoxic events, Mar. Ecol.-Prog. Ser., 357, 1-16, 2008.

Larsson, U., Elmgren, R., and Wolff, F.: Eutrophication of the 
Baltic Sea: Causes and consequences, Ambio, 14, 9-14, 1985.

Leppäkoski, E.: Assessment of degree of pollution on the basis of macrozoobenthos in marine and brackish water environments, Acta Academiae Aboensis B35, 1975.

Levin, L. A. and Gage, J. D.: Relationships between oxygen, organic matter and the diversity of bathyal macrofauna, Deep-Sea Res. Pt. II, 45, 129-163, 1998.

Levin, L. A., Whitcraft, C. R., Mendoza, G. F., Gonzalez, J. P., and Cowie, G. L.: Oxygen and organic matter thresholds for benthic faunal activity on the Pakistan Margin oxygen minimum zone (700-1100 m), Deep-Sea Res. Pt. II, 56, 449-471, 2009.

Levin, L. A.: Oxygen minimum zone benthos: Adaptation and community response to hypoxia, Oceanogr. Mar. Biol. , 41, 1-45, 2003.

Levin, L. A., Gutiérrez, D., Rathburn, A. E., Neira, C., Sellanes, J., Muñoz, P., Gallardo, V. A., and Salamanca M. A.: Benthic processes on the Peru margin: A transect across the oxygen minimum zone during the 1997-98 El Niño, Prog. Oceanogr., 53, 1-27, 2002.

Levin, L. A., Huggett, C. L., and Wishner, K. F.: Control of deepsea benthic community structure by oxygen and organic matter gradients in the eastern Pacific Ocean, J. Mar. Res., 49, 763-800, 1991.

Levin, L. A., Gage, J., Lamont, P., Cammidge, L., Patience, A., and Martin, C.: Infaunal community structure in a low-oxygen organic rich habitat on the Oman continental slope, NW Arabian Sea, in: Responses of marine organisms to their environment, edited by: Hawkins, L., Hutchinson, S., Jenson, A., Williams, J., and Sheader, M., Proc. 30th European Marine Biology Symposium, Southampton, UK, 1995, 223-230, 1997.

Levin, L. A., Gage, J. D., Martin, C., and Lamont, P. A.: Macrobenthic community structure within and beneath the oxygen minimum zone, NW Arabian Sea, Deep-Sea Res. Pt. II, 47, 189226, 2000.

Levin, L. A., Ziebis, W., Mendoza, G. F., Growney, V. A., Tryon, M. D., Brown, K. M., Mahn, C., Gieskes, J. M., and Rathburn, A. E.: Spatial heterogeneity of macrofauna at northern California methane seeps: influence of sulfide concentration and fluid flow, Mar. Ecol.-Progr. Ser., 265, 123-139, 2003.

Li, D. J., Zhang, J., Huang, D. J,. Wu, Y., and Liang, J.: Oxygen depletion off the Changjiang (Yangtze River) Estuary, Sci. China Ser. D, 45, 1137-1146, 2002.

Long, W. C., Brylawski, B. J., and Seitz, R.: Behavioral effects of low dissolved oxygen on the bivalve Macoma balthica, J. Exp. Mar. Biol. Ecol., 359, 34-39, 2008.

Lozán, L. J., Lampe, R., Matthäus, W., Rachor, E., Rumohr, H., and Westernhagen, H. v. (Eds.): Warnsignale aus der Ostsee, Parey, Berlin, 385 pp., 1996.

Lu, L. and Wu, R. S. S.: An experimental study on recolonization and succession of marine macrobenthos in defaunated sediment, Mar. Biol., 136, 291-302, 2000.

Macpherson, E. and Gordoa, A.: Biomass spectra in benthic fish assemblages in the Benguela System, Mar. Ecol.-Prog. Ser., 138, 27-32, 1996.

Mazumder, A., Henriques, P. J., and Nigam, R.: Distribution of benthic foraminifera within oxygen minimum zone off central west coast, India, Gondwana Geol. Mag., 6, 5-10, 2003.

Mazzola, A., Mirto, S., and Danovaro, R.: Initial fish-farm impact on meiofaunal assemblages in coastal sediments of the Western
Mediterranean, Mar. Pollut. Bull., 38, 1126-1133, 1999.

Mazzola, A., Mirto, S., La Rosa, T., Fabiano, M., and Danovaro, R.: Fish-farming effects on benthic community structure in coastal sediments: analysis of meiofaunal recovery, ICES J. Mar. Sci., 57, 1454-1461, 2000.

McClatchie, S., Goericke, R., Cosgrove, R., and Vetter, R.: Oxygen in the southern California Bight: multidecadal trends, impact of El Niño and implications for demersal fisheries, Limnol. Oceanogr., in review, 2009.

McGlathery, K. J., Sundbäck, K., and Anderson, I. C.: Eutrophication in shallow coastal bays and lagoons: the role of plants in the coastal filter, Mar. Ecol.-Prog. Ser., 348, 1-18, 2007.

Mee, D., Friedrich, J., and Gomoiu, M.: Restoring the Black Sea in times of uncertainty, Oceanography, 18, 100-112, 2005.

Middleburg, J. and Levin, L. A.: Coastal hypoxia and sediment biogeochemistry, Biogeosciences 6, 1273-1293, 2009.

Miller, D., Poucher, S., and Coiro, L.: Determination of lethal dissolved oxygen levels for selected marine and estuarine fishes, crustaceans, and a bivalve, Mar. Biol., 140, 287-296, 2002.

Mirto, S., La Rosa, T., Danovaro, R. and Mazzola, A.: Microbial and meiofaunal response to intensive mussel-farm biodeposition in coastal sediments of the western Mediterranean, Mar. Pollut. Bull., 40, 244-252, 2000.

Mirto, S., La Rosa, T., Gambi, C., Danovaro, R., and Mazzola, A.: Nematode community response to fish-farm impact in the western Mediterranean, Environ. Pollut., 116, 203-214, 2002.

Mohrholz, V., Bartholomae, C. H., van der Plas, A. K., and Lass, H. U.: The seasonal variability of the northern Benguela undercurrent and its relation to the oxygen budget on the shelf, Cont. Shelf Res., 28, 424-441, 2007.

Monteiro, P. M. S. and van der Plas, A. K.: Low oxygen water (LOW) variability in the Benguela system: key processes and forcing scales relevant to forecasting, in: The Benguela: predicting a large marine ecosystem, Large Marine Ecosytems, edited by: Shannon, V., Hempel, G., Malanotte-Rizzoli, P., Moloney, C. and Woods, J., Elsevier Series, Amsterdam, 14, 71-90, 2006.

Monteiro, P. M. S., van der Plas, A., Mohrholz, V., Mabille, E., Pascall, A., and Joubert, W.: Variability of natural hypoxia and methane in a coastal upwelling system: oceanic physics or shelf biology, Geophys. Res. Lett., 33, L16614, doi:10.1029/2006GL026234, 2006.

Monteiro, P. M. S., van der Plas, A. K., Mélice, J.-L., and Florenchie, P.: Interannual hypoxia variability in a coastal upwelling system: ocean-shelf exchange, climate and ecosystem-state implications, Deep-Sea Res. Pt. I, 55, 435-450, 2008.

Montserrat, F., van Colen, C., Degraer, S., Ysebaert, T., and Herman, P. M. J.: Benthic community-mediated sediment dynamics, Mar. Ecol.-Prog. Ser., 372, 43-59, 2008.

Moodley, L., Schaub, B. E. M., van der Zwaan, G. J., and Herman, P. M. L.: Tolerance of benthic foraminifera (Protista: Sarcodina) to hydrogen sulphide, Mar. Ecol.-Prog. Ser., 169, 77-86, 1998.

Moodley, L., van der Zwaan, G. J., Herman, P. M. J., Kempers, L. and van Breugel, P.: Differential response of benthic meiofauna to anoxia with special reference to Foraminifera (Protista: Sarcodina), Mar. Ecol.-Prog. Ser., 158, 151-163, 1997.

Mountain, D.: Potential consequences of climate change for the fish resources in the mid-Atlantic region, Fisheries in a Changing Climate, American Fisheries Society Symposium, 32, 185-194, 2002. 
Mountford, N. K., Holland, A. F., and Mihursky, J. A.: Identification and description of macrobenthic communities in the Calvert Cliffs region of the Chesapeake Bay, Chesapeake Sci., 14, 160369, 1977.

Murray, J. W.: Ecology and applications of benthic Foraminifera, Cambridge University Press, Cambridge, New York, Melbourne, Madrid, Cape Town, Singapore, São Paulo, 2006.

Murray, J. W.: The niche of benthic foraminifera, critical thresholds and proxies, Mar. Micropaleontol., 41, 1-7, 2001.

Murrell, M. and Fleeger, J. W.: Meiofauna abundance on the Gulf of Mexico continental shelf affected by hypoxia, Cont. Shelf. Res., 9, 1049-1062, 1989.

Muthumbi, A. W., Vanreusel, A., Duineveld, G., Soetaert, K., and Vincx, M.: Nematode community structure along the continental slope off the Kenian coast, Western Indian Ocean, Int. Rev. Hydrobiol., 89, 188-205, 2004.

Naqvi, S. W. A., George, M.D., Narvekar, P. V., Jayakumar, D. A., Shailaja, M. S., Sardesai, S., Sarma, V. V. S. S., Shenoy, D. M., Naik, H., Maheswaran, P. A., Krishnakumari, K., Rajesh, G., Sudhir, A. K., and Binu, M. S.: Severe fish mortality associated with "red tide" observed in the sea off Cochin, Curr. Sci., 75, 543-544, 1998.

Naqvi, S. W. A., Jayakumar, D. A., Narvekar, P. V., Naik, H., Sarma, V. V. S. S., D'Souza, W., Joseph, S., and George, M. D.: Increased marine production of $\mathrm{N}_{2} \mathrm{O}$ due to intensifying anoxia on the Indian continental shelf, Nature, 408, 346-349, 2000.

Naqvi, S. W., Naik, H., Jayakumar, D. A., Shailaja, M. S., and Narvekar, P. V.: Seasonal oxygen deficiency over the western continental shelf of India, in: Past and Present Water Column Anoxia, edited by: Neretin, L. N., Dordrecht, The Netherlands, 195-224, 2006.

Naqvi, S. W. A., Naik, H., Jayakumar, D. A., Pratihary, A. K., Narvenkar, G., Kurian, S., Agnihotri, R., Shailaja, M. S., and Narvekar, P. V.: Seasonal anoxia over the western Indian continental shelf, in: Indian Ocean Biogeochemical Processes and Ecological Variability, edited by: Wiggert, J., Hood, R., Naqvi, S. W. A., et al., American Geophysical Union, Washington DC, USA, in press, 2009.

Nausch, G., Matthaus, W., and Feistel, R.: Hydrographic and hydrochemical conditions in the Gotland Deep area between 1992 and 2003, Oceanologia, 45, 557-569, 2003.

Neira, C., Sellanes J., Levin, L. A., and Arntz, W. E.: Meiofaunal distributions on the Peru margin: relationship to oxygen and organic matter availability, Deep-Sea Res. Pt. I, 48, 2453-2472, 2001a.

Neira, C., Sellanes, J., Soto, A., Gutiérrez, D., and Gallardo, V. A.: Meiofauna and sedimentary organic matter off central Chile: response to changes caused by the 1997-1998 El Niño, Oceanol. Acta, 24, 313-328, 2001b.

Neira, C. and Rackemann, M.: Black spots produced by buried macroalgae in intertidal sandy sediments of the Wadden Sea: effects on the meiobenthos, J. Sea Res., 36, 153-170, 1996.

Nelsen, T. A., Blackwelder, P., Hood, T., McKee, B., Romer, N., Alvarez-Zarikian, C., and Metz, S.: Time-based correlation of biogenic, lithogenic and authigenic sediment components with anthropogenic inputs in the Gulf of Mexico NECOP study area, Estuaries, 17, 873-885, 1994.

Newell, R. I. E. and Koch, E.: Modeling seagrass density and distribution in response to changes in turbidity stemming from bivalve filtration and seagrass sediment stabilization, Estuaries, 27, 793806, 2004.

Newell, R. I. E.: Ecological changes in Chesapeake Bay: are they the result of overharvesting the eastern oyster (Crassostrea virginica)?, in: Understanding the Estuary: Advances in Chesapeake Bay Research, edited by: Lynch, M. P. and Krome, E.C., Chesapeake Research Consortium Publication, 129, 536-546, 1988.

Nigam, R., Mazumder, A., Henriques, P., and Saraswat, S.: Benthic foraminifera as proxy for oxygen-depleted conditions off the central West coast of India, J. Geol. Soc. India, 70, 1047-1054, 2007.

Nilsson, H. C. and Rosenberg, R.: Succession in marine benthic habitats and fauna in response to oxygen deficiency: analysed by sediment profile-imaging and by grab samples, Mar. Ecol.-Prog. Ser., 197, 139-149, 2000.

Nilsson, H. C. and Rosenberg, R.: Hypoxic response of two marine benthlc communities, Mar. Ecol.-Prog. Ser., 115, 209-217, 1994.

Nissling A. and Westin L.; Salinity requirements for successful spawning of Baltic and Belt Sea cod and the potential for cod stock interactions in the Baltic Sea. Mar Ecol Prog. Series, 152, 261271, 1997.

Nixon, S. W.: Coastal marine eutrophication: a definition, social causes, and future concerns, Ophelia, 41, 199-219, 1995.

Officer, C. B., Biggs, R. B., Taft, J. L., Cronin, L. E., Tyler, M. A., and Boynton, W. R.: Chesapeake Bay anoxia: origin, development, and significance, Science, 223, 22-27, 1984.

Ohde, T., Siegel, H., Reißmann, J., and Gerth, M.: Identification and investigation of sulphur plumes along the Namibian coast using the MERIS sensor, Cont. Shelf Res., 27, 744-756, 2007.

Olenin, S.: Benthic zonation of the eastern Gotland Basin, Baltic Sea, Netherlands, J. Aq. Ecol., 30, 265-282, 1997.

Osterman, L. E., Poore, R. Z., and Swarzenski, P. W.: The last 1000 years of natural and anthropogenic low-oxygen bottom-water on the Louisiana shelf, Gulf of Mexico, Mar. Micropaleontol., 66, 291-303, 2008.

Osterman, L. E.: Benthic foraminifers from the continental shelf and slope of the Gulf of Mexico: an indicator of shelf hypoxia, Estuar. Coast. Shelf S., 58, 17-35, 2003.

O'Toole, M. J.: Development, distribution and relative abundance of the larvae and early juveniles of the pelagic goby Sufflogobius bibarbatus (von Bonde) off South West Africa, 1972-1974, Sea Fisheries Branch Investigational Report, 116, Dept. of Industries, RSA, Cape Town, RSA., 1-28, 1978.

O'Toole, M. J. and Bartholomae, C.: An overview of marine environmental conditions off Namibia during 1994-1995. Proceedings of Annual Research Meeting, February 1995. Windhoek: Ministry of Fisheries and Marine Resources, 1995.

Palmer, M. A.: Dispersal of marine meiofauna: a review and conceptual model explaining passive transport and active emergence with implications for recruitment, Mar. Ecol.-Prog. Ser., 48, 8191, 1988.

Panchang, R., Nigam, R., Linshy, V., Rana, S. S., and Ingole, B. S.: Effect of oxygen manipulations on benthic foraminifera: a preliminary experiment, Indian J. Mar. Sci., 35, 235-239, 2006

Parulekar, A. H., Harkantra, S. N., and Ansari, Z. A.: Benthic production and assessment of demersal fishery resources of the Indian seas, Indian J. Mar. Sci., 11, 107-114, 1982.

Pavela, J. S., Ross, J. L. and Chittenden, M. E.: Sharp reductions in 
abundance of fishes and benthic macroinvertebrates in the Gulf of Mexico off Texas associated with hypoxia, Northeast Gulf Sci., 6, 167-173, 1983.

Paulmier, A. and Ruiz-Pino, D.: Oxygen minimum zones (OMZs) in the modern ocean, Prog. Oceanogr., 77, 331-350, doi:10.1016/j.pocean.2008.08.001, 2008.

Pearson, T. H. and Rosenberg, R.: Macrobenthic succession in relation to organic enrichment and pollution of the marine environment, Oceanogr. Mar. Biol., 16, 229-311, 1978.

Pearson, T. H. and Rosenberg, R.: Feast and famine: Structuring factors in marine benthic communities, in: Organization of Communities Past and Present, edited by: Gee, J. H. R. and Giller, P. S., Blackwell, Oxford, 373-395, 1987.

Phleger, F. B., and Soutar, A.: Production of benthic foraminifera in three east Pacific oxygen minima, Micropaleontology, 19, 110115, 1973.

Phleger, F. B.: Benthic Foraminifera as indicators of organic production in marginal marine areas, in: 1st International Symposium on Benthic Foraminifera of Continental Margins. Part A: Ecology and Biology, Maritime Sediments Special Publication, 1, 107-117, 1976.

Pihl, L., Baden, S. P., and Diaz, R. J.: Effects of periodic hypoxia on distribution of demersal fish and crustaceans, Mar. Biol., 108, 349-360, 1991.

Pihl, L., Baden, S. P., Diaz, R. J., and Schaffner, L. C.: Hypoxia induced structural changes in the diets of bottom-feeding fish and crustacea, Mar. Biol., 112, 349-362, 1992.

Platon, E., Sen Gupta, B. K., Rabalais, N. N., and Turner, R. E.: Effect of seasonal hypoxia on the benthic foraminiferal community of the Louisiana inner continental shelf: the 20th century record, Mar. Micropaleontol., 54, 263-283, 2005.

Plus, M., Deslous-Paoli, J. M., and Dagault, F.: Seagrass (Zostera marina L.) bed recolonisation after anoxia-induced full mortality, Aquat. Bot., 77, 121-134, 2003.

Pörtner, H. O. and Knust, R.: Climate change affects marine fishes through the oxygen limitation of thermal tolerance, Science, 315 , 95-97, 2007.

Powell, E. N.: Oxygen, sulfide and diffussion: why thiobiotic meiofauna must be sulfide-insensitive first-order respirers, J. Mar. Res., 47, 887-932, 1989.

Powers, S. P., Harper Jr., D. E., and Rabalais, N. N.: Effects of hypoxia/anoxia on the supply and settlement of benthic invertebrate larvae, in: Coastal and estuarine studies: coastal hypoxia consequences for living resources and ecosystems, edited by: Rabalais, N. N. and Turner, R. E., American Geophysical Union, Washington, D. C., 185-210, 2001.

Qu, J. G., Xu, Z. L., Long, Q., Wang, L., Shen, X. M., Zhang, J., and Cai, Y. L.: East China Sea, UNEP/GIWA Regional Assessment 36, University of Kalmar, Sweden, 96 pp., 2005.

Quiroga, E., Quinoñes, R., Palma, M., Sellanes, J., Gallardo, V., Gerdes, D. and Rowe, G.: Biomass size-spectra of macrobenthic communities in the oxygen minimum zone off Chile, Estuar. Coast. Shelf S., 62, 217-231, 2005.

Quiroga, E., Quiñones, R. A., González, R. R., Gallardo, V. A., and Jessen, G.: Aerobic and anaerobic metabolism of Paraprionospio pinnata (Polychaeta: Spionidae) in central Chile, J. Mar. Biol. Assoc. UK, 87, 459-463, 2007.

Rabalais, N. N. and Turner, R. E.: Hypoxia in the Northern Gulf of Mexico: description, causes and change, in: Coastal and estu- arine studies: coastal hypoxia consequences for living resources and ecosystems, edited by: Rabalais, N. N. and Turner, R. E., American Geophysical Union, Washington, D. C., 1-36, 2001.

Rabalais, N. N., Harper Jr., D. E., and Turner, R. E.: Responses of nekton and demersal and benthic fauna to decreasing oxygen concentrations, in: Coastal and estuarine studies: coastal hypoxia consequences for living resources and ecosystems, edited by: Rabalais, N. N. and Turner, R. E., American Geophysical Union, Washington, D. C., 115-128, 2001a.

Rabalais, N. N., Smith, L. E., Harper Jr., D. E., and Dubravko, J.: Effects of seasonal hypoxia on continental shelf benthos, in: Coastal and estuarine studies: coastal hypoxia consequences for living resources and ecosystems, edited by: Rabalais, N. N. and Turner, R. E., American Geophysical Union, Washington, D. C., 211-240, 2001b.

Rabalais, N. N., Turner, R. E., Díaz, R. J., and Justić, D.: Climate change and eutrophication of coastal waters, ICES J. Mar. Sci., in press, 2009.

Rabalais, N. N., Turner, R. E., Justic, D., Dortch, Q., and Wiseman Jr., W. J., and Sen Gupta, B.K.: Nutrient changes in the Mississippi River and system responses on the adjacent continental shelf, Estuaries, 19, 386-407, 1996.

Rabalais, N. N., Turner, R. E., Sen Gupta, B. K., Boesch, D. F., Chapman, P., and Murrell, M. C.: Characterization and longterm trends of hypoxia in the northern Gulf of Mexico: does the science support the action plan?, Estuaries Coasts, 30, 753-772, 2007a.

Rabalais, N. N., Turner, R. E., Sen Gupta, B. K., Platon, E., and Parsons, M. L.: Sediments tell the history of eutrophication and hypoxia in the northern Gulf of Mexico, Ecol. Appl., 17, S129S143, 2007b.

Rabalais, N. N.: Eutrophication, in: The global coastal ocean: multiscale interdisciplinary processes, The Sea, edited by: Robinson, A. R., McCarthy, J., and Rothschild, B. J., President and Fellows of Harvard College, USA, 13, 819-865, 2004.

Rahmstorf, S.: Thermohaline ocean circulation, in: Encyclopedia of quaternary sciences, edited by: Elias, S. A., Elsevier, Amsterdam, 2006.

Rainer, S. F. and Fitzhardinge, R. C.: Benthic communities in an estuary with periodic deoxygenation, Aust. J. Mar. Fresh. Res., 32, 227-243, 1981.

Ramaiah, N., Fernandes, P. J. T., Raveendran, T., Raveendran, O., Sunder, D., Revichandran, C., Shenoy, D. M., Gauns, M., Kurian, S., Gerson, J. J., Shoji, D. T., Madhu, N. V., Dree, K. S., Lokabharathi, P. A., and Shetye, S. R.: The September 2004 stench off the southern Malabar coast - a consequence of holococcolithophore bloom, Curr. Sci. India, 88, 551-54, 2005.

Renaud, M.: Hypoxia in Louisiana coastal waters during 1983: implications for fisheries, Fish. B.-NOAA, 84, 19-26, 1986.

Rhoads, D. C., Aller, R. C., and Goldhaber, M. B.: The influence of colonizing benthos on physical properties and chemical diagenesis on the estuarine seafloor, in: Ecology of marine benthos, edited by: Coull, B. C., University of South Carolina Press, Columbia, 113-138, 1977.

Risgaard-Petersen, N., Langezaal, A. M., Ingvardsen, I., Schmid, M. C., Jetten, M. S. M., Op den Camp, H. J. M., Derksen, J. W. M., Piña-Ochoa, E., Eriksson, S. P., Nielsen, L. P., Revsbech, N. P., Cedhagen, T., and van der Zwaan, G. J.: Evidence for complete denitrification in a benthic foraminifer, Nature, 443, 
93-96, 2006.

Rosa, R. and Siebel, B.: Synergistic effects of climate-related variables suggests future physiological impairment in a top oceanic predator, P. Natl. Acad. Sci. USA, 105(52), 20776-20780, doi:10.1073/pnas.0806886105, 2008.

Rosenberg, R., Agrenius, S., Hellman, B., Nilsson, H. C., and Norling, K.: Recovery of marine benthic habitats and fauna in a Swedish fjord following improved oxygen conditions, Mar. Ecol.-Prog. Ser., 234, 43-53, 2002.

Rosenberg, R., Hellman, B., and Johansson, B.: Hypoxic tolerance of marine benthic fauna, Mar. Ecol.-Prog. Ser., 79, 127-131, 1991.

Rosenberg, R., Nilsson, H. C., and Diaz, R. J.: Response of benthic fauna and changing sediment redox profiles over a hypoxic gradient, Estuar. Coast. Shelf S., 53, 343-350, 2001.

Rosenberg, R.: Benthic faunal dynamics during succession following pollution abatement in a Swedish estuary, Oikos, 27, 414427, 1976.

Rosenberg, R.: Benthic faunal recovery in a Swedish Fjord following the closure of a sulphite pulp mill, Oikos, 23, 92-108, 1972.

Rosenberg, R.: Marine benthic faunal successional stages and related sedimentary activity, Sci. Mar., 65 (Suppl. 2), 107-119, 2001.

Sagasti, A., Schaffner, L. C., and Duffy, J. E.: Effects of periodic hypoxia on mortality, feeding and predation in an estuarine epifaunal community, J. Exp. Mar. Biol. Ecol., 258, 257-283, 2001.

Sakko, A. L.: The influence of the Benguela upwelling system on Namibia's marine biodiversity, Biodivers. Conserv., 7, 419-433, 1998.

Sanders, H.: Benthic marine diversity and the stability-time hypothesis, Brookhaven Symposia on Biology, 22, 71-81, 1969.

Santos, S. L. and Simon, J. L.: Marine soft-bottom community establishment following annual defaunation: larval or adult recruitment, Mar. Ecol.-Prog. Ser., 2, 235-241, 1980.

Shaffer G., Hormazabal, S., Pizarro, O. and Salinas, S.: Seasonal and interannual variability of currents and temperature off central Chile, J. Geophys. Res., 104, 29 951-29 961, 1999.

Schaffer, G., Pizarro, O., Hormazabal, S., and Venegas, S.: Imprint of El Niño/La Niña cycles on the Humboldt Current system, Investig. Mar., v.30 n.1, supl. Symp. Valparaíso ago, 2002.

Schaffner, L. C., Jonsson, P., Diaz, R. J., Rosenberg, R., and Gapcynski, P.: Benthic communities and bioturbation history of estuarine and coastal systems: effects of hypoxia and anoxia, Sci. Total Environ. (supplement), 1001-1017, 1992.

Schmaljohann, R., Drews, M., Walter, S., Linke P., von Rad, U., and Imbhoff, J. F.: Oxygen minimum zone sediments in the northeastern Arabian Sea off Pakistan: a habitat for the bacterium Thioploca, Mar. Ecol.-Progr. Ser., 200, 27-42, 2001.

Schramm, W.: Factors influencing seaweed responses to eutrophication: some results from EU-project EUMAC, J. Appl. Phycol., 11, 69-78, 1999.

Schulz, H. N., Brinkhoff, T., Ferdelman, T. G., Hernandez Marine, M., Teske, A., and Jørgensen, B. B.: Dense populations of a giant sulfur bacterium in Namibian shelf sediments, Science, 284, 493-495. 1999.

Schulz, H. N. and de Beer, D.: Uptake rates of oxygen and sulfide measured with individual Thiomargarita namibiensis cells by using microelectrodes, Appl. Environ. Microb., 68, 57465749, 2002.
Sellanes, J. and Neira, C.: ENSO as a natural experiment to understand environmental control of meiofaunal community structure, Mar. Ecol., 27, 31-43, 2006.

Sellanes, J., Neira, C., and Quiroga, E.: Composition, structure and energy flux of the meiobenthos off central Chile, Rev. Chil. Hist. Nat., 76, 401-415, 2003.

Sellanes, J., Quiroga, E., Neira, C., and Gutiérrez, D.: Changes of macrobenthos composition under different ENSO cycle conditions on the continental shelf off central Chile, Cont. Shelf Res., 27, 1002-1016, 2007.

Sen Gupta, B. K., Lee, R. F., and May, M. S: Upwelling and an unusual assemblage of benthic foraminifera on the northern Florida continental slope, J. Paleontol., 55, 853-857, 1981.

Sen Gupta, B. K. and Platon, E.: Tracking past sedimentary records of oxygen depletion in coastal waters: use of the AmmoniaElphidium foraminiferal index, J. Coastal Res., 39, 1351-1355, 2006.

Sen Gupta, B. K., Turner, R. E., and Rabalais, N. N.: Seasonal oxygen depletion in continental-shelf waters of Lousiana: Historical record of benthic foraminifers, Geology, 24, 227-230, 1996.

Sen Gupta, B. K. and Machain-Castillo, M. L.: Benthic foraminifera in oxygen-poor habitats, Mar. Micropaleontol., 20, 183-201, 1993.

Sergeeva, N. G. and Gulin, M. B.: Meiobenthos from an active methane seepage area in the NW Black Sea, Mar. Ecol., 28, 152159, 2007.

Sergeeva, N. G., Zaika, V. E., and Kiseleva, M. I.: Two polychaete species bordering deep anoxic waters in the Black Sea, Tavrichesky me.-biolog. Vestnik, 56-60, 1999.

Shannon, L. V.: Evolution of the Benguela, physical features and processes, in: The Benguela Ecosystem Part I, edited by: Barnes, M., Aberdeen University Press, Oceanogr. Mar. Biol., 23, 105$182,1985$.

Shapiro, G. I., Alenynik, D. L., and Mee, L. D.: Interannual and interdecadal variability of the physical environment in the Black Sea revisited, Geophys. Res. Abstr., 8, EGU06-A00985, 2006.

Sindermann, C. J. and Swanson, R. L.: Oxygen depletion and associated benthic mortalities in New York Bight, 1976, Historical and Regional Perspective, NOAA Professional Paper 11, 1-16, 1979.

Smith, C. R., Levin, L. A., Hoover, D. J., McMurty, G., and Gage, J. D.: Variations in bioturbation across the oxygen minimum zone in the northwest Arabian Sea, Deep-Sea Res. Pt. II, 47, 227-257, 2000.

Smith, R. D., Pregnall, A. M., and Alberte, R. S.: Effects of anaerobiosis on root metabolism of Zostera marina (eelgrass) - Implications for survival in reducing sediments, Mar. Biol., 98, 131$141,1988$.

Sohlenius, G., Emies, K.-C., Andrén, E., Andrén, T., and Kohly, A.: Development of anoxia during the Holocene fresh - brackish water transition in the Baltic Sea, Mar. Geol., 177, 221-242, 2001.

Soliman, Y. and Rowe, G.: Secondary production of Ampelisca mississippiana Soliman and Wicksten 2007 (Amphipoda, Crustacea) in the head of the Mississippi Canyon, northern Gulf of Mexico, Deep-Sea Res. Pt. II, 55, 2692-2698, 2008.

Sorokin, Y.: The Black Sea: Ecology and Oceanography, Backhuys, Leiden, The Netherlands, 2002.

Stachowitsch, M.: Anoxia in the northern Adriatic Sea: Rapid 
death, slow recovery, in: Modern and ancient continental shelf anoxia, edited by: Tyson, R. V. and Pearson, T. H., Geological Society Special Publication No. 58, 119-129, 1991.

Stachowitsch, M.: Benthic communities: Eutrophication's "memory mode", in: Marine coastal eutrophication, edited by: Vollenweider, R. A., Marchetti, R., and Viviani, R., Sci. Total Environ., 1017-1028, 1992.

Stachowitsch, M.: Mass mortality in the Gulf of Trieste: the course of community destruction, PSZNI Mar. Ecol., 5, 243-264, 1984.

Stramma, L., Johnson, G. C., Sprintall, J. and Mohrholz, V.: Expanding oxygen-minimum zones in the tropical oceans, Science, 320, 655-658, 2008.

Stramma, L., Levin, L. A., Schmidt, S., and Johnson, G. C.: Tropical ocean desertification and biological impacts, Deep-Sea Res., in review, 2009.

Sunbäck, K. and Graneli, W.: Influence of microphytopbenthos on the nutrient flux between sediment and water: a laboratory study, Mar. Ecol.-Prog. Ser., 43, 63-69, 1988.

Tang, Q. S. (Ed.): Study on ecosystem dynamics in coastal ocean III. Atlas of resources and environment of east China Sea and Yellow Sea. Science Press, Beijing, 398 pp., 2004 (in Chinese).

Tang, Q.S. (Ed.): The living marine resources and inhabiting environment in the Chinese exclusive economic zone, Science Press, Beijing, 1237 pp., 2006 (in Chinese).

Tarazona, J., Arntz, W., Valle, S., and Peña, T.: Los indices de El Niño y del impacto sobre las comunidades bentonicas, in: El Niño en America Latina, Impactos biologicos y socials, edited by: Tarazona, J., Arntz, W., and Castillo, E., Consejo Nacional de Ciencia y Tecnologia, Lima, Peru, 113-126, 2001.

Tarazona, J., Salzwedel, H., and Arntz, W.: Oscillations of macrobenthos in shallow waters of the Peruvian central coast induced by El Niño 1982-83, J. Mar. Res., 46, 593-611, 1988a.

Tarazona, J., Salzwedel, H., and Arntz, W.: Positive effects of "El Niño" on macrozoobenthos inhabitating hypoxic areas of the Peruvian upwelling system, Oecologia, 76, 184-190, 1988b.

Thistle, D.: The response of a harpacticoid copepod community to a small-scale natural disturbance, J. Mar. Res., 38, 381-395, 1980.

Tsuchiya, M., Grimm, G. W., Heinz, P., Stogerer, K., Topac, K., Collen, J., Bruchert, V., Hemleben, C., Hemleben, V., and Kitazato, H.: Ribosomal DNA shows extremely low genetic divergence in a world-wide distributed, but disjunct and highly adapted marine protozoan (Virgulinella fragilis, Foraminiferida), Mar. Micropaleontol., 70, 8-19, doi:10.1016/j.marmicro.2008.10.001, 2008.

Tsutsumi, H., Kikuchi, T., Tanaka, M., Higashi, T., Imasaka, K., and Miyazaki, M.: Benthic faunal succession in a cove organically polluted by fish farming, Mar. Pollut. Bull., 23, 233-238, 1991.

Tulkki, P.: Disappearance of the benthic fauna from the basin of Bornholm (southern Baltic) due to oxygen deficiency, Cah. Biol. Mar., 6, 455-563, 1965.

Turner, R. E. and Rabalais, N. N.: Linking landscape and water quality in the Mississippi River basin for 200 years, Bioscience, 53, 563-572, 2003.

Tyler, R. M., Brady, D. C. and Targett, T. E.: Temporal and spatial dynamics of diel-cycling hypoxia in estuarine tributaries, Estuaries and Coasts, 32, 123-145, 2009.

Tyson, R. V. and Pearson, T. H. (Eds.): Modern and ancient continental shelf anoxia, Geological Society of London Special Publication No. 58, 470 pp., 1991.
Tuzzolino, D.: Examining the prey resource value of dielcycling hypoxia impacted benthic habitat for juvenile weakfish (Cynoscion regalis) and summer flounder (Paralichthys dentatus) in an estuarine tributary, Masters Thesis in Marine Biosciences, University of Delaware, Lewes, Delaware, 2008.

Vadeboncoeur, Y., Jeppesen, E., Vander Zanden, M. J., Schierup, H. H., Christoffersen, K., and Lodge, D. M.: From Greenland to green lakes: Cultural eutrophication and the loss of benthic pathways in lakes, Limnol. Oceanogr., 48, 1408-1418, 2003.

Valiela, I., McClelland, J., Hauxwell, J., Behr, P. J., Hersh, D., and Foreman, K.: Macroalgal blooms in shallow estuaries: Controls and ecophysiological and ecosystem consequences, Limnol. Oceanogr., 42, 1105-1118, 1997.

Van Colen, C., Monserrat, F., Verbist, K., Vincx, M., Steyaert, M., Vanaverbeke, J., Herman, P.M.J., Degraer, S., and Ysebaert, T.: Tidal flat nematode responses to hypoxia and subsequent macrofauna-mediated alterations of sediment properties, Mar. Ecol. Progr. Ser., 381, 189-197, 2009.

Van Colen, C., Monserrat, F., Vincx, M., Herman, P.M.J., Ysebaert, T., and Degraer, S.: Macrobenthic recovery from hypoxia in an estuarine tidal mudflat, Mar. Ecol. Progr. Ser., 372, 31-42, 2008.

van der Plas, A. K., Monteiro, P. M. S., and Pascall, A.: Crossshelf biogeochemical characteristics of sediments in the central Benguela and their relationship to overlying water column hypoxia, Afr. J. Mar. Sci., 29, 37-47, 2007.

Van der Zwaan, G. J. and Jorissen, F. J.: Biofacial patterns in riverinduced shelf anoxia, in: Modern and ancient continental shelf anoxia, No. 58, edited by: Tyson, R. V. and Pearson, T. H., Geological Society Special Publication, London, UK, 65-82, 1991.

Vanreusel, A., Vincx, M., Schram, D., and Van Gansbeke, D.: On vertical distribution of the metazoan meiofauna in shelf break and upper slope habitats of the NE Atlantic, Int. Rev. Ges. Hydrobio., 80, 313-326, 1995.

Vaquer-Sunyer, R. and Duarte, C. M.: Thresholds of hypoxia for marine biodiversity. P. Natl. Acad. Sci. USA, 105, 15452 15457,2008

Varshney, P. K., Govindan, K., Gaikwad, U. D., and Desai, B. N.: Macrobenthos off Versova (Bombay), west coast of India, in relation to environmental conditions, Indian J. Mar. Sci., 17, 222227, 1988.

Veit-Kohler, G., Gerdes, D., Quiroga, E., Hebbeln, D., and Sellanes, J.: Metazoan meiofauna within the oxygen-minimum zone off Chile: results of the 2001-PUCK expedition, Deep-Sea Res. Pt. II 56, 1105-1111, 2009.

Verity, P. G., Alber, M. and Bricker, S. B.: Development of hypoxia in well-mixed subtropical estuaries in the southeastern USA, Estuaries and Coasts, 29, 665-673, 2006.

Vinogradov, M. E.: Long-term variability of the pelagic community structure in the open Black Sea, in: Problems of the Black Sea, International Conference on Problems of the Black Sea, Sevastopol, Ukraine 1-15 November, 19-33, 1992.

Walters, K.: Diel vertical migration of sediment-associated meiofauna in subtropical sand and seagrass habitats, J. Exp. Mar. Biol. Ecol., 117, 169-186, 1988.

Wannamaker, C. M. and Rice, J. A.: Effects of hypoxia on movements and behavior of selected estuarine organisms from the southeastern United States, J. Exp. Mar. Biol. Ecol., 249, 145$163,2000$.

Warwick, R. M., Platt, H. M., Clarke, K. R., Agard, J. and Gobin, 
J.: Analysis of macrobenthic and meiobenthic community structure in relation to pollution and disturbance in Hamilton Harbour, Bermuda, J. Exp. Mar. Biol. Ecol., 138, 119-142, 1990.

Weeks, S., Currie, B., and Bakun, A.: Massive emission of toxic gas in the Atlantic, Nature, 415, 493-494, 2002.

Weeks, S., Currie, B., Bakun, A., and Peard, K. R.: Hydrogen sulphide eruptions in the Atlantic Ocean off southern Africa: Implications of a new view based on SeaWiFS satellite imagery, Deep-Sea Res. Pt. I, 51, 153-172, 2004.

Wenzhofer, F., Riess, W., and Luth, U.: In situ macrofaunal respiration rates and their importance for benthic carbon mineralization rates on the northwestern Black Sea shelf, Ophelia, 56, 87-100, 2002.

Westernhagen, H. V. and Dethlefsen, V.: North sea oxygen deficiency 1982 and its effects on the bottom fauna, Ambio, 12, 264266, 1983.

Wetzel, M. A., Fleeger, J. W., and Powers, S. P.: Effects of hypoxia and anoxia on meiofauna: a review with new data from the Gulf of Mexico, in: Coastal and estuarine studies: coastal hypoxia consequences for living resources and ecosystems, edited by: Rabalais, N. N. and Turner, R. E., American Geophysical Union, Washington, D. C., 165-184, 2001.

Wieser, W. and Kanwisher, J.: Ecological and physiological studies on marine nematodes from a small salt marsh near Woods Hole, Massachusetts, Limnol. Oceanogr., 6, 262-270, 1961.

Willard, D. A. and Cronin, T. M.: Paleoecology and ecosystem restoration: case studies from Chesapeake Bay and the Florida Everglades, Front. Ecol. Environ., 5, 491-498, doi:10.1890/070015, 2007.

Woulds, C., Andersson, J. H., Cowie, G. L., Middelburg J. J., and Levin, L. A.: The short-term fate of organic carbon in marine sediments: comparing the Pakistan margin to other regions, Deep-Sea Res. Pt. II, 56, 393-402, 2009.

Woulds, C., Cowie, G. L., Levin, L. A., Andersson, J. H., Middelburg, J. J., Vandewiele, S. Lamont, P. A., Larkin, K. E., Gooday, A. J., Schumacher, S., Whitcraft, C., Jeffreys R. M., and Schwartz, M. C.: Oxygen as a control on seafloor biological communities and their roles in sedimentary carbon cycling, Limnol. Oceanogr., 52, 1698-1709, 2007.
Wu, R. S. S.: Periodic defaunation and recovery in a subtropical epibenthic community, in relation to organic pollution, J. Exp. Mar. Biol. Ecol., 64, 253-269, 1982.

Wu, R. S. S.: Hypoxia: from molecular responses to ecosystem responses, Mar. Pollut. Bull., 45, 35-45, 2002.

Zaitsev, Y. P.: Recent changes in the trophic structure of the Black Sea, Fish. Oceanogr., 1, 180-189, 1992.

Zettler, M.L., Bochert R. and Pollehne F.; Macrozoobenthos diversity in an oxygen minimum zone off northern Namibia. Mar. Biol., doi: 10.10007/s00227-009-1227-9, 2009

Zhang, J. and Su, J. L.: Nutrient dynamics of the Chinese Seas: The Bohai, Yellow Sea, East China Sea and South China Sea, in: The Sea, edited by: Robinson, A. R. and Brink, K. H., Harvard University Press, Cambridge MA, 14, 637-671, 2006.

Zhang, J., Liu, S. M., Ren, J. L., Wu, Y., and Zhang, G. L.: Nutrient gradients from the eutrophic Changjiang (Yangtze River) Estuary to the oligotrophic Kuroshio waters and re-evaluation of budgets for the East China Sea Shelf, Prog. Oceanogr., 74, 449478, 2007.

Zheng, Y. J., Chen, X. Z., Cheng, J. H., Wang, Y. L,. Shen, X. Q., Chen, W. Z., and Li, C. S. (Eds.): Living marine resources and environment of East China Sea shelf, Shanghai Science \& Technology Press, Shanghai, 835 pp., 2003 (in Chinese).

Zhu, Z. Y.: Hypoxia in the Changjiang Estuary and its adjacent area - Started with phytoplankton pigments. Ph.D Dissertation, East China Normal University, Shanghai, 209 pp., 2007 (in Chinese).

Zillén, L., Conley, D. J., Andrén, T., Andrén, E., and Björck, S.: Past occurrences of hypoxia in the Baltic Sea and the role of climate variability, environmental change and human impact, Earth Sci. Rev., 91, 77-92, 2008

Zimmerman, A. R. and Canuel, E. A.: Sediment geochemical records of eutrophication in the mesohaline Chesapeake Bay, Limnol. Oceanogr., 47, 1084-1093, 2002. 